\title{
Hydrogeologic Framework and Groundwater Conditions of the Ararat Basin in Armenia
}

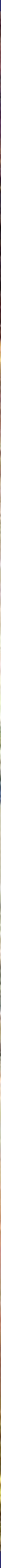

Scientific Investigations Report 2017-5163

U.S. Department of the Interior

U.S. Geological Survey 
Cover. This astronaut photograph, taken from the International Space Station, highlights a segment of the international border between Armenia and Turkey. The Aras River separates the two countries, with Armenia to the north-northeast and Turkey to the south-southwest. Extensive green agricultural fields are common on both sides of the river (upper part of image), as well as a number of gray-totan urban areas including Yerevan (image top, slightly left of center) and Artashat and Armavir in Armenia, and Iğdır in Turkey. While there have been efforts to normalize diplomatic relations between the two countries in recent years, the Armenia-Turkey border remains officially closed.

The dominant geographic feature in the region is Mt. Ararat, also known as Agri Dagi. The peak of Ararat, a large stratovolcano that last erupted in 1840 according to historical records, is located approximately 40 kilometers to the south of the Armenia-Turkey border. A lower peak to the east, known as Lesser or Little Ararat or Lil Sis, is also volcanic in origin. Dark gray lava flows to the south of Mt. Ararat are located near the Turkish border with Iran. While this border is also closed along much of its length, official crossing points allow relatively easy travel between the two countries.

The white, glacier-clad peak of Mt. Ararat is evident at image center; dark green areas on the lower slopes indicate where vegetation cover is abundant. A large lake, Balik Golu or Fish Lake, is visible to the west (image lower left).

Source of photograph and description: National Aeronautics and Space Administration Earth Observatory, ISS Expedition 28 crew, July 8, 2011.

Back cover. Photographs of the study area showing Mt. Ararat in the background. 


\section{Hydrogeologic Framework and Groundwater Conditions of the Ararat Basin in Armenia}

By Joshua F. Valder, Janet M. Carter, Colton J. Medler, Ryan F. Thompson, and Mark T. Anderson

Scientific Investigations Report 2017-5163 


\title{
U.S. Department of the Interior \\ RYAN K. ZINKE, Secretary
}

\section{U.S. Geological Survey \\ William H. Werkheiser, Deputy Director exercising the authority of the Director}

\author{
U.S. Geological Survey, Reston, Virginia: 2018
}

For more information on the USGS - the Federal source for science about the Earth, its natural and living resources, natural hazards, and the environment-visit https://www.usgs.gov or call 1-888-ASK-USGS.

For an overview of USGS information products, including maps, imagery, and publications,

visit https://store.usgs.gov.

Any use of trade, firm, or product names is for descriptive purposes only and does not imply endorsement by the U.S. Government.

Although this information product, for the most part, is in the public domain, it also may contain copyrighted materials as noted in the text. Permission to reproduce copyrighted items must be secured from the copyright owner.

Suggested citation:

Valder, J.F., Carter, J.M., Medler, C.J., Thompson, R.F., and Anderson, M.T., 2018, Hydrogeologic framework and groundwater conditions of the Ararat Basin in Armenia: U.S. Geological Survey Scientific Investigations Report 2017-5163, 40 p., https://doi.org/10.3133/sir20175163.

ISSN 2328-0328 (online) 


\section{Acknowledgments}

The authors thank Magda Avetisyna, Aram Gevorgyan, Lilith Harutyunyan, and Benyamin Zakaryan, U.S. Agency for International Development (USAID) contractors with the Advanced Science and Partnership for Integrated Resource Development (ASPIRED) program, for their help obtaining Armenian hydrologic and geologic data, translation, hospitality, and collaboration for this study. Staff of the Hydrogeological Monitoring Center in Yerevan, Armenia, collected data on the status of wells, water levels, and basic field water-quality constituents in the Ararat Basin during the summer of 2016. The authors also thank Naram Chanmugam, Patrick Meyer, and Marina Vardanyan, USAID, for providing funding and guidance for this study and for their hospitality in Armenia. 



\section{Contents}

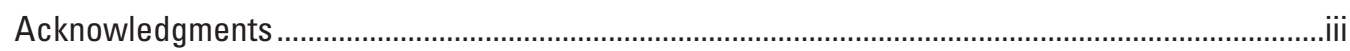

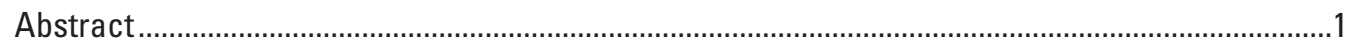

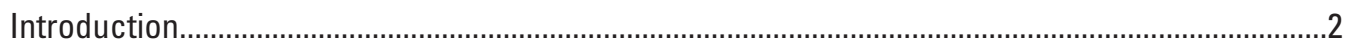

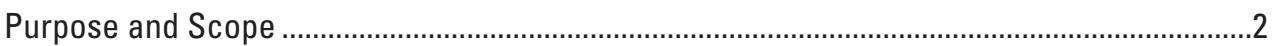

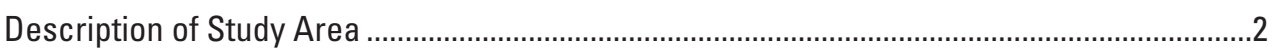

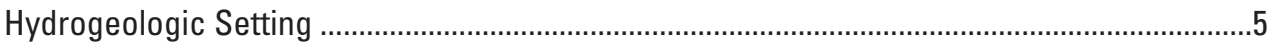

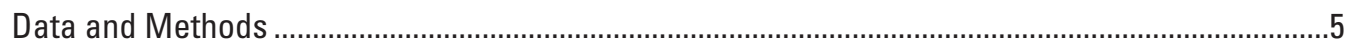

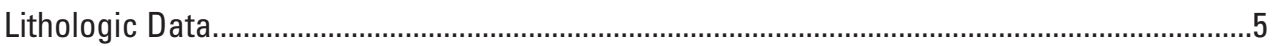

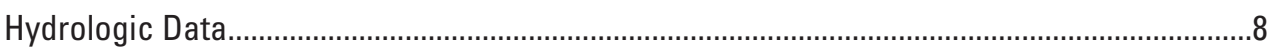

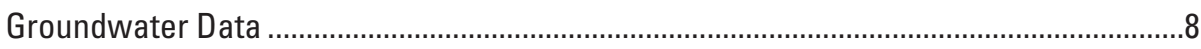

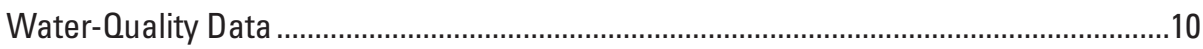

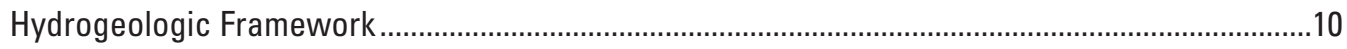

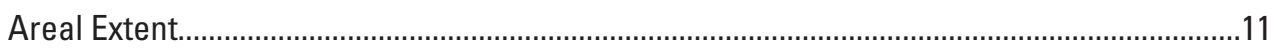

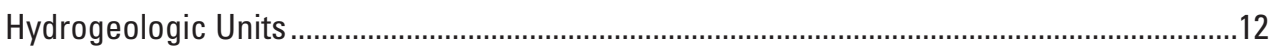

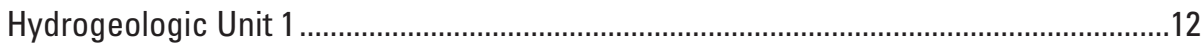

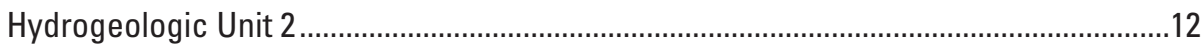

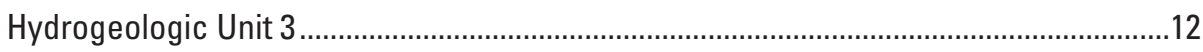

Hydrogeologic Unit 4 .......................................................................................

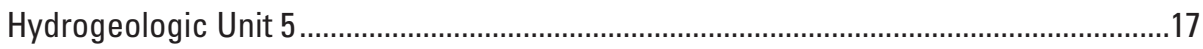

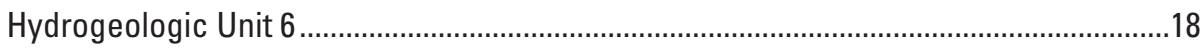

Hydrogeologic Unit 7 ....................................................................................... 18

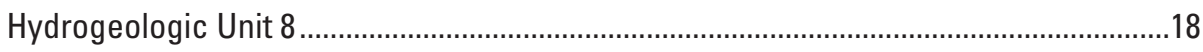

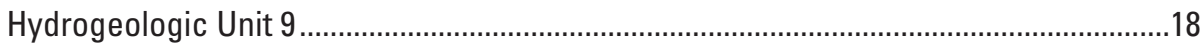

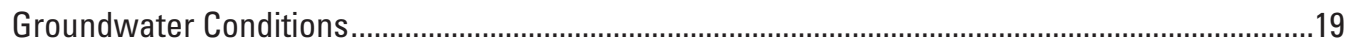

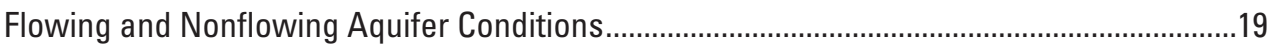

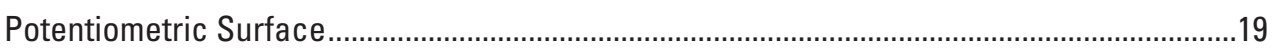

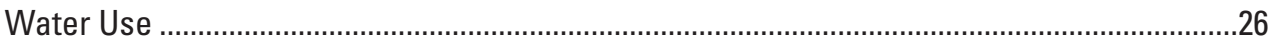

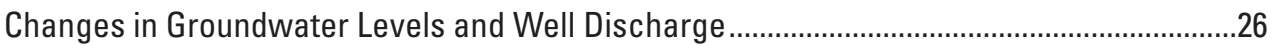

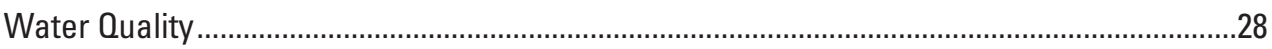

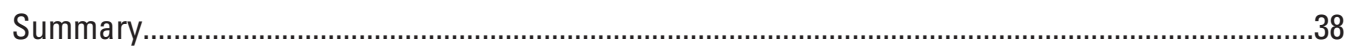

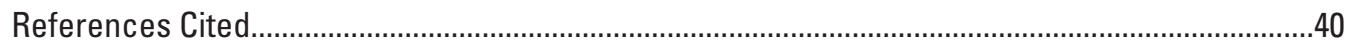

\section{Figures}

1. Map showing location of the Ararat Basin (study area) in Armenia and Turkey...............3

2. Map showing digital elevation model of Ararat Basin ...................................................

3. Chart showing hydrogeologic units of the study area interpreted from lithologic logs as described in table 1 .........................................................................................

4. Photographs showing collection of hydrologic data on March 2, 2016, as part

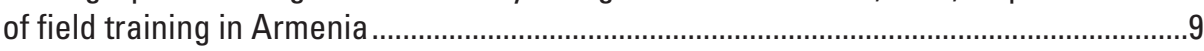

5. Photograph showing collection of stable-isotope sample from a flowing well (U.S. Geological Survey site 400250044235601) in the Ararat Basin, Armenia 
6. Three-dimensional special interpretation of the Ararat Basin, Armenia, derived from lithologic logs provided by the Advanced Science and Partnerships for Integrated Resource Development group

7. Map of three subbasin areas and three cross sections of the Ararat Basin, Armenia, used to define the nine hydrogeologic units.

8. Graphs showing number and distribution of wells used to generate thicknesses for each of the nine hydrogeologic units in the Ararat Basin, Armenia.

9. Maps showing thickness of all nine hydrogeologic units in the Ararat Basin, Armenia .

10. Map showing location of flowing and nonflowing wells in 2016 and locations of the 1984, 2007, and 2016 pressure boundaries between flowing and non-flowing wells in the study area of the Ararat Basin in Armenia

11. Map showing location of wells included in the $\mathbf{2 0 1 6}$ well inventory by hydrogeologic unit in the study area of the Ararat Basin in Armenia

12. Map showing potentiometric surface of hydrogeologic unit 2 in the study area of the Ararat Basin in Armenia.

13. Map showing potentiometric surface of hydrogeologic unit 4 in the study area in the Ararat Basin in Armenia .

14. Map showing potentiometric surface of hydrogeologic unit 6 in the study area of the Ararat Basin in Armenia.

15. Map showing potentiometric surface of hydrogeologic unit 8 in the study area of the Ararat Basin in Armenia.

16. Maps showing spatial distribution of wells with various water uses in 2016 in the study area of the Ararat Basin in Armenia

17. Photograph showing an abandoned well flowing water to the land surface in November 2015 in the Ararat Basin in Armenia

18. Map showing location of and well discharge from nonoperational, abandoned flowing wells with discharge to waste in 2016 in the study area of the Ararat Basin in Armenia ...

19. Pie diagram showing percentage of wells by use of water based on wells inventoried in 2016 in the study area of the Ararat Basin in Armenia

20. Map showing well discharge rates for flowing wells used for irrigation in the study area of the Ararat Basin in Armenian in 2016

21. Map showing well discharge rates for flowing wells used for fish farming in the study area of the Ararat Basin in Armenia in 2016.

22. Map showing locations of current (2016) and previous wells used for drinking water in the study area of the Ararat Basin in Armenia

23. Map showing difference in hydraulic heads between 2007 and 2016 in the study area of the Ararat Basin in Armenia.

24. Map showing spatial distribution of specific conductance in water from wells in the study area of the Ararat Basin in Armenia in 2016

25. Bar chart showing distribution of ranges of specific conductance values in the study area of the Ararat Basin in Armenia in 2016

26. Map showing spatial distribution of water temperature in wells in the study area of the Ararat Basin, Armenia, in 2016.

27. Graph showing isotopic composition of water samples from wells and Hrazdan River in the study area of the Ararat Basin compared to Global Meteoric Water Line (Craig, 1961). 


\section{Tables}

1. Lithologic descriptions, land-surface elevations, geologic layer thicknesses, and hydrogeologic units of the Ararat Basin, Armenia.

2. Lithologic descriptions, thickness, and water-bearing potential for 24 unique lithological materials based on lithologic logs for wells drilled in the Ararat Basin, Armenia

3. Water-level and well discharge data collected in the Ararat Basin by U.S. Geological Survey in March 2016

4. Hydrologic data provided to the U.S. Geological Survey from the 2016 well inventory conducted in the Ararat Basin, Armenia, by Armenian partners

5. Historical water-level data from 2007 in the Ararat Basin, Armenia, provided to the U.S. Geological Survey by Armenian partners

6. Historical water-level and well yield data from various dates ranging from 1981 to 2013 in the Ararat Basin, Armenia

7. Water-quality data collected or analyzed by U.S. Geological Survey in March 2016 in the Ararat Basin, Armenia

8. Summary of each unit detailing the number of wells used in defining the geologic material, the average unit thickness across the Ararat Basin, and the maximum measured and interpolated thicknesses within each of the hydrogeologic units

\section{Conversion Factors}

International System of Units to U.S. customary units

\begin{tabular}{|c|c|c|}
\hline Multiply & By & To obtain \\
\hline \multicolumn{3}{|c|}{ Length } \\
\hline millimeter $(\mathrm{mm})$ & 0.03937 & inch (in.) \\
\hline meter $(\mathrm{m})$ & 3.281 & foot $(\mathrm{ft})$ \\
\hline kilometer (km) & 0.6214 & mile (mi) \\
\hline \multicolumn{3}{|c|}{ Area } \\
\hline hectare (ha) & 2.471 & acre \\
\hline square kilometer $\left(\mathrm{km}^{2}\right)$ & 247.1 & acre \\
\hline hectare (ha) & 0.003861 & square mile $\left(\mathrm{mi}^{2}\right)$ \\
\hline square kilometer $\left(\mathrm{km}^{2}\right)$ & 0.3861 & square mile $\left(\mathrm{mi}^{2}\right)$ \\
\hline \multicolumn{3}{|c|}{ Volume } \\
\hline milliliter $(\mathrm{mL})$ & 0.03381 & ounce, fluid (fl. oz) \\
\hline liter (L) & 0.2642 & gallon (gal) \\
\hline cubic meter $\left(\mathrm{m}^{3}\right)$ & 264.2 & gallon (gal) \\
\hline cubic kilometer $\left(\mathrm{km}^{3}\right)$ & 0.2399 & cubic mile $\left(\mathrm{mi}^{3}\right)$ \\
\hline \multicolumn{3}{|c|}{ Flow rate } \\
\hline liter per second $(\mathrm{L} / \mathrm{s})$ & 15.85 & gallon per minute (gal/min) \\
\hline \multicolumn{3}{|c|}{ Mass } \\
\hline kilogram (kg) & 2.205 & pound avoirdupois (lb) \\
\hline metric ton $(\mathrm{t})$ & 2204.62 & pound avoirdupois (lb) \\
\hline
\end{tabular}


Temperature in degrees Celsius $\left({ }^{\circ} \mathrm{C}\right)$ may be converted to degrees Fahrenheit $\left({ }^{\circ} \mathrm{F}\right)$ as follows:

$$
{ }^{\circ} \mathrm{F}=\left(1.8 \times{ }^{\circ} \mathrm{C}\right)+32 .
$$

Temperature in degrees Fahrenheit $\left({ }^{\circ} \mathrm{F}\right)$ may be converted to degrees Celsius $\left({ }^{\circ} \mathrm{C}\right)$ as follows:

$$
{ }^{\circ} \mathrm{C}=\left({ }^{\circ} \mathrm{F}-32\right) / 1.8 \text {. }
$$

\section{Datum}

Horizontal coordinate information is referenced to the World Geodetic System of 1984 (WGS 84).

Vertical coordinate information is referenced to the World Geodetic System of 1984 (WGS 84).

Elevation, as used in this report, refers to distance above the vertical datum.

\section{Supplemental Information}

Specific conductance is given in microsiemens per centimeter at 25 degrees Celsius $(\mu \mathrm{S} / \mathrm{cm}$ at $\left.25^{\circ} \mathrm{C}\right)$.

Results for measurements of stable isotopes of an element (with symbol E) in water, solids, and dissolved constituents commonly are expressed as the relative difference in the ratio of the number of the less abundant isotope ('E) to the number of the more abundant isotope of a sample with respect to a measurement standard.

\section{Abbreviations}

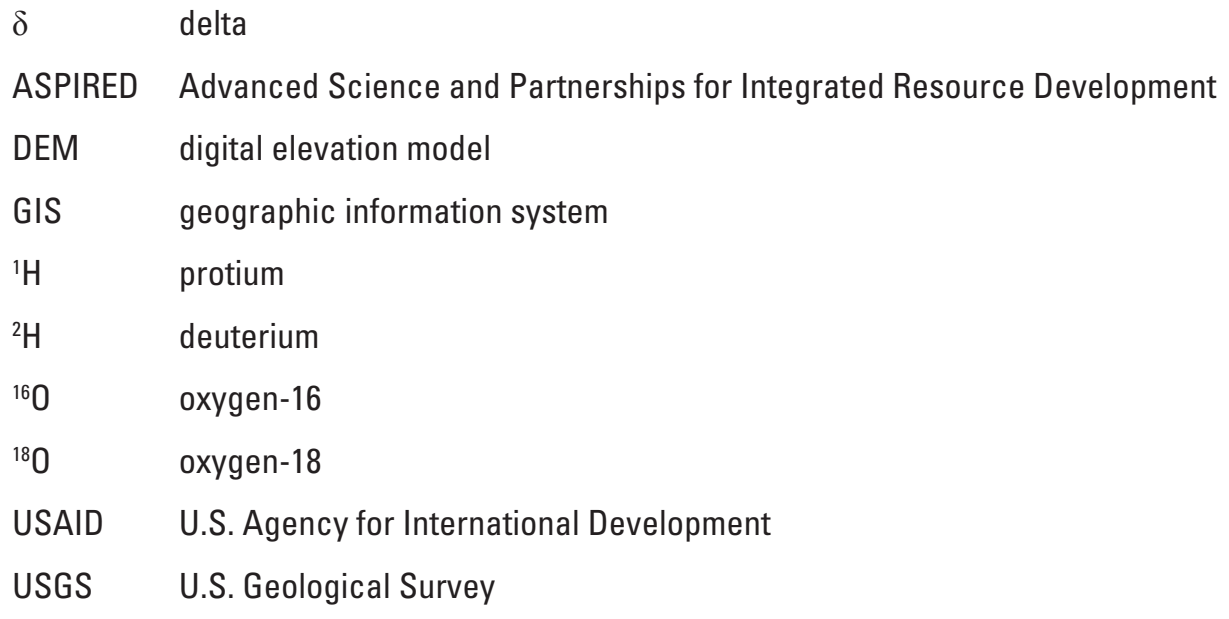

USAID U.S. Agency for International Development

USGS U.S. Geological Survey 


\title{
Hydrogeologic Framework and Groundwater Conditions of the Ararat Basin in Armenia
}

\author{
By Joshua F. Valder, Janet M. Carter, Colton J. Medler, Ryan F. Thompson, and Mark T. Anderson
}

\section{Abstract}

Armenia is a landlocked country located in the mountainous Caucasus region between Asia and Europe. It shares borders with the countries of Georgia on the north, Azerbaijan on the east, Iran on the south, and Turkey and Azerbaijan on the west. The Ararat Basin is a transboundary basin in Armenia and Turkey. The Ararat Basin (or Ararat Valley) is an intermountain depression that contains the Aras River and its tributaries, which also form the border between Armenia and Turkey and divide the basin into northern and southern regions. The Ararat Basin also contains Armenia's largest agricultural and fish farming zone that is supplied by high-quality water from wells completed in the artesian aquifers that underlie the basin. Groundwater constitutes about 40 percent of all water use, and groundwater provides 96 percent of the water used for drinking purposes in Armenia. Since 2000, groundwater withdrawals and consumption in the Ararat Basin of Armenia have increased because of the growth of aquaculture and other uses. Increased groundwater withdrawals caused decreased springflow, reduced well discharges, falling water levels, and a reduction of the number of flowing artesian wells in the southern part of Ararat Basin in Armenia.

In 2016, the U.S. Geological Survey and the U.S. Agency for International Development (USAID) began a cooperative study in Armenia to share science and field techniques to increase the country's capabilities for groundwater study and modeling. The purpose of this report is to describe the hydrogeologic framework and groundwater conditions of the Ararat Basin in Armenia based on data collected in 2016 and previous hydrogeologic studies. The study area includes the Ararat Basin in Armenia. This report was completed through a partnership with USAID/Armenia in the implementation of its Science, Technology, Innovation, and Partnerships effort through the Advanced Science and Partnerships for Integrated Resource Development program and associated partners, including the Government of Armenia, Armenia's Hydrogeological Monitoring Center, and the USAID Global Development Lab and its GeoCenter.

The hydrogeologic framework of the Ararat Basin includes several basin-fill stratigraphic units consisting of interbedded dense clays, gravels, sands, volcanic basalts, and andesite deposits. Previously published cross sections and well lithologic logs were used to map nine general hydrogeologic units. Hydrogeologic units were mapped based on lithology and water-bearing potential. Water-level data measured in the water-bearing hydrogeologic units 2, 4, 6, and 8 in 2016 were used to create potentiometric surface maps. In hydrogeologic unit 2, the estimated direction of groundwater flow is from the west to north in the western part of the basin (away from the Aras River) and from north to south (toward the Aras River) in the eastern part of the basin. In hydrogeologic unit 4 , the direction of groundwater flow is generally from west to east and north to south (toward the Aras River) except in the western part of the basin where groundwater flow is toward the north or northwest. Hydrogeologic unit 6 has the same general pattern of groundwater flow as unit 4. Hydrogeologic unit 8 is the deepest of the water-bearing units and is confined in the basin. Groundwater flow generally is from the south to north (away from the Aras River) in the western part of the basin and from west to east and north to south (toward the Aras River) elsewhere in the basin.

In addition to water levels, personnel from Armenia's Hydrogeological Monitoring Center also measured specific conductance at 540 wells and temperature at 2,470 wells in the Ararat Basin using U.S. Geological Survey protocols in 2016. The minimum specific conductance was 377 microsiemens per centimeter $(\mu \mathrm{S} / \mathrm{cm})$, the maximum value was $4,000 \mu \mathrm{S} / \mathrm{cm}$, and the mean was $998 \mu \mathrm{S} / \mathrm{cm}$. The maximum water temperature was 24.2 degrees Celsius. An analysis between water temperature and well depth indicated no relation; however, spatially, most wells with cooler water temperatures were within the 2016 pressure boundary or in the western part of the basin. Wells with generally warmer water temperatures were in the eastern part of the basin.

Samples were collected from four groundwater sites and one surface-water site by the U.S. Geological Survey in 2016. The stable-isotope values were similar for all five sites, indicating similar recharge sources for the sampled wells. The Hrazdan River sample was consistent with the groundwater samples, indicating the river could serve as a source of recharge to the Ararat artesian aquifer. 


\section{Introduction}

Armenia is a landlocked country located in the mountainous Caucasus region between Asia and Europe. It shares borders with the countries of Georgia on the north, Azerbaijan on the east, Iran on the south, and Turkey and Azerbaijan on the west (fig. 1). Armenia has an area of about 29,700 square kilometers $\left(\mathrm{km}^{2}\right)$. Its population in 2015 was approximately 3 million (U.S. Census Bureau, 2016). Approximately onethird of the population lives in the capital city of Yerevan (World Population Review, 2016). Groundwater supplies 96 percent of the water used for drinking water purposes, and about 40 percent of all water withdrawn in the country is from groundwater (Yu and others, 2014). Agriculture depends heavily on groundwater irrigation and more than 80 percent of the gross crop production is from irrigated lands (Yu and others, 2014).

The Ararat Basin lies between the Caucasus Mountains to the north and the Armenian Plateau to the south. The Aras River divides the basin into northern and southern regions and also forms Armenia's border with Turkey (fig. 1). Elevations within the Ararat Basin range from 800 to 1,000 meters (m) (fig. 2, table 1). The Ararat Basin occupies an area of about $1,300 \mathrm{~km}^{2}$ (Armenian Branch of Mendez England and Associates, 2014). About 8 percent of the population of Armenia lives in the Ararat Basin (U.S. Agency for International Development, 2008). The Ararat Basin supports the largest agriculture and fish farming zones in Armenia (Yu and others, 2014).

Table 1. Lithologic descriptions, land-surface elevations, geologic layer thicknesses, and hydrogeologic units of the Ararat Basin, Armenia (available online at https://doi.org/10.3133/ sir20175163).

Since 2000, aquaculture demands and other uses have increased groundwater withdrawals in the Ararat Basin. Increased groundwater withdrawals resulted in decreased springflows, reduced well discharges, lower well water levels, and a reduction of the number of flowing artesian wells in the southern part of Ararat Basin (Armenia Branch of Mendez England and Associates, 2014; Yu and others, 2014). In 2013, groundwater use by aquaculture alone exceeded the sustainable level of groundwater resources, and the total groundwater use for all purposes in the Ararat Basin was 1.6 times the sustainable level (Yu and others, 2014). Increased groundwater withdrawals have also affected other water uses. Flowing artesian wells supplying drinking and irrigation water to 31 communities have ceased flowing. The Armenian Nuclear Power Plant at Metsamor (fig. 1) cannot meet water requirements (Yu and others, 2014). Streamflows and lake levels have diminished as a result of aquifer depletion (Armenia Branch of Mendez England and Associates, 2014). Additionally, there are numerous abandoned flowing wells in the Ararat Basin and some continue to discharge water to the land's surface, creating environmental hazards and continued depletion of the artesian aquifers in the basin (Nalbandyan, 2012; Carter and others, 2016).

In 2016, the U.S. Geological Survey (USGS) and the U.S. Agency for International Development (USAID) began a cooperative study with Armenia to share science and field techniques to increase the country's capabilities for groundwater study and modeling (Carter and others, 2016). This study is in partnership with USAID/Armenia in the implementation of its Science, Technology, Innovation, and Partnerships effort through the Advanced Science and Partnerships for Integrated Resource Development (ASPIRED) program and associated partners, including the Government of Armenia, Armenia's Hydrogeological Monitoring Center, and the USAID Global Development Lab and its GeoCenter. These techniques can be used by groundwater-resource managers, such as those in Armenia's Ministry of Nature Protection, to understand and predict the consequences of their resource management decisions. One of the objectives for this study was to characterize the hydrogeologic framework and groundwater conditions in the Ararat Basin.

\section{Purpose and Scope}

The purpose of this report is to describe the hydrogeologic framework and groundwater conditions of the Ararat Basin study area in Armenia. Specifically, the report describes the lithology and hydrogeologic units in the study area. The hydrogeologic framework and groundwater conditions are characterized through existing geologic maps, lithologic data from drilled wells, remote sensing imagery, well records and logs, and groundwater-level measurements and other field data collected across the basin. For the artesian units that underlie the Ararat Basin study area, the hydraulic properties, discharge, and changes in hydraulic head and storage through 2016 are described.

\section{Description of Study Area}

The Ararat Basin (also known as the Ararat Valley) is an intermountain depression that contains the Aras River and its tributaries (Armenian Branch of Mendez England and Associates, 2014). The Aras River has a drainage area of approximately $31,500 \mathrm{~km}^{2}$, of which 14,900 $\mathrm{km}^{2}$ is in Armenia and $16,600 \mathrm{~km}^{2}$ is in Turkey (Armenian Branch of Mendez England and Associates, 2014). The study area includes the Ararat Basin in Armenia (fig. 2) and is slightly larger than the "Ararat artesian basin" defined by Armenian Branch of Mendez England and Associates (2014) because the study area boundary was expanded to include locations of all wells inventoried in 2016.

The Ararat Basin is the most arid region of Armenia with annual precipitation of about 200-250 millimeters (mm) (Nalbandyan, 2012). Despite the arid climate, this region contains the country's largest agricultural and fish farming 


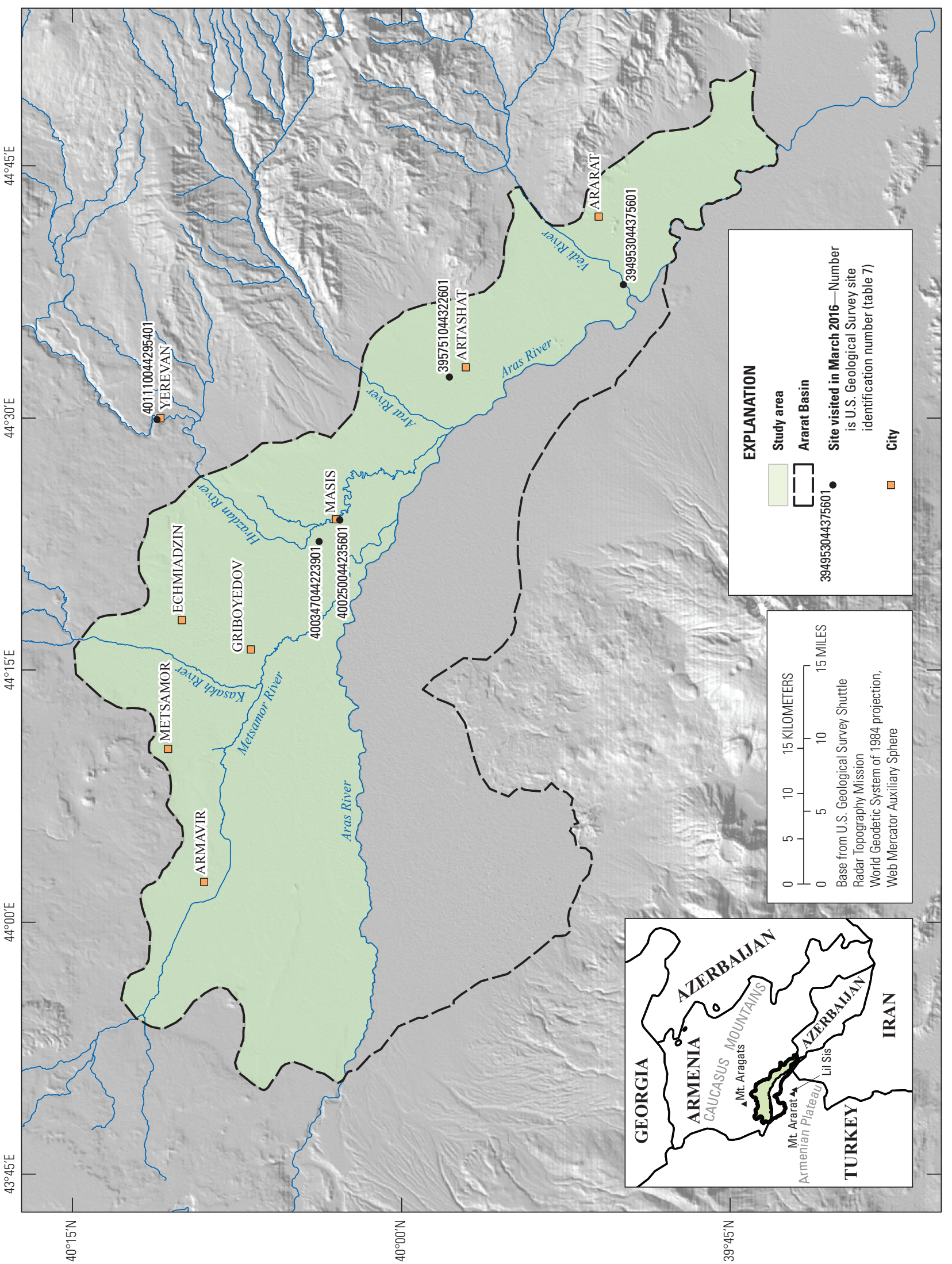

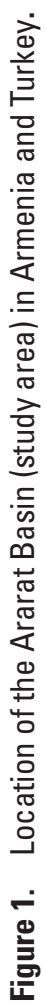




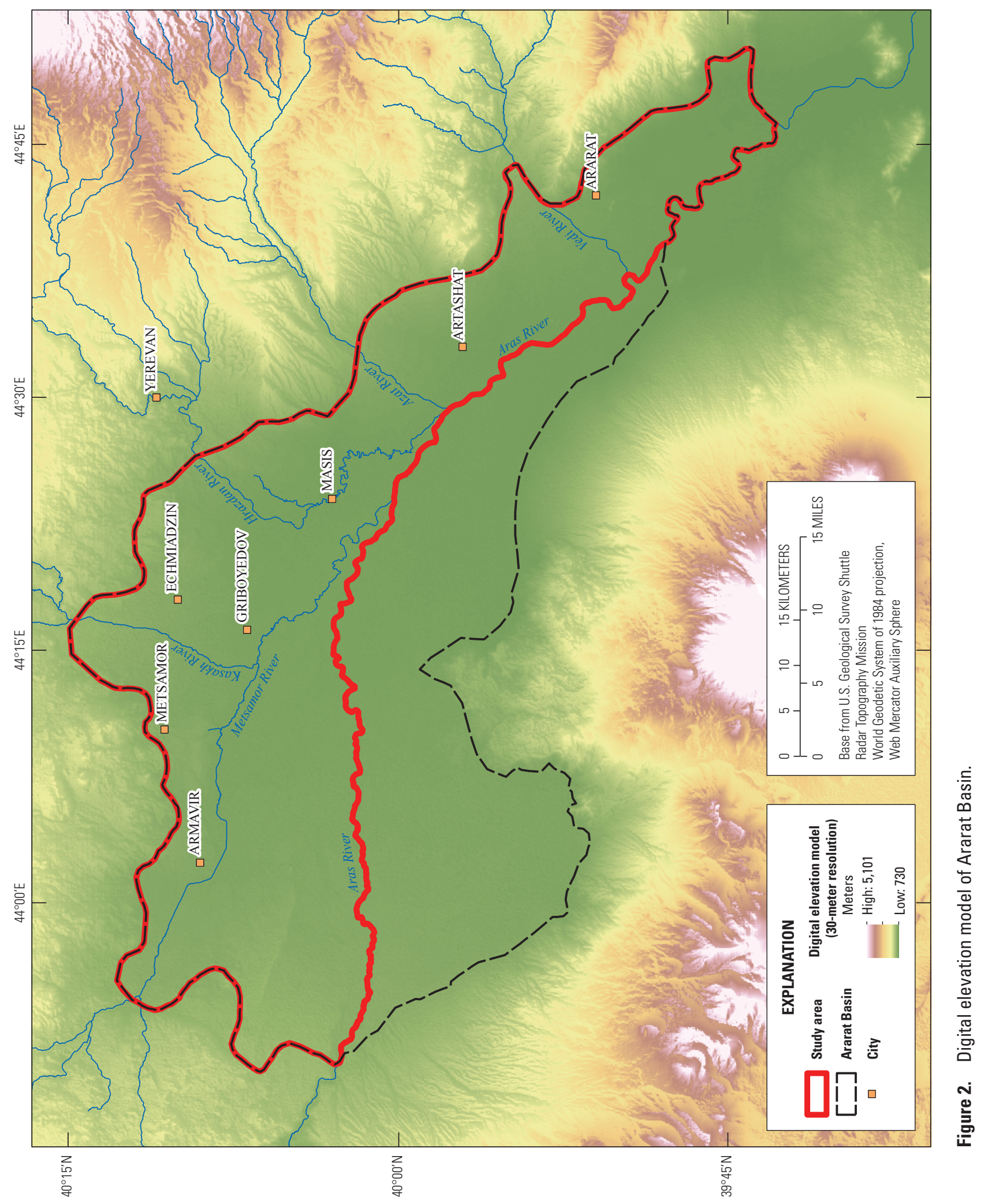


zone supported by generally high-quality water from wells completed in the artesian aquifer (Yu and others, 2014).

The water also is suitable for human consumption without additional treatment (Yu and others, 2014). The artesian aquifer is contained in Quaternary deposits of lava, primarily porous and fractured basalts. Approximately 80 percent of springs in the Ararat Basin originate from these lava deposits (Nalbandyan, 2012). Recharge to the artesian aquifer is through direct infiltration of precipitation and loss of flow in surface streams, especially in upland areas.

The mean annual water withdrawal from surface-water and groundwater sources in Armenia is about 8,000 cubic meters per hectare, with groundwater irrigation consuming about 70 percent of that withdrawal (Nalbandyan, 2012). Groundwater withdrawn from the basin's artesian aquifer is used for municipal, irrigation, energy, industrial, and aquaculture. In July 2008, the 477 water withdrawal points in the basin were used for the following purposes: 63 percent for irrigation, 12 percent for energy, 11 percent for industrial, 9 percent for drinking, and 6 percent for aquaculture (sums to 101 percent due to rounding; U.S. Agency for International Development, 2008).

Within the Ararat Basin, about 267 fish farms were developed to raise trout, sturgeon, and other cold-water fish, with about 190 fish farms in operation in 2015 (Meyer, 2015). For fishery purposes, the Ministry of Nature Protection issued permits for 576 wells with a total discharge rate of approximately 43,200 liters per second (L/s) (Meyer, 2015). Armenia produces about 11,500 metric tons of fish annually (Meyer, 2015).

\section{Hydrogeologic Setting}

The Ararat Basin is a transboundary basin located in Armenia and Turkey. The Ararat Basin is an asymmetrical shaped basin bounded by Mount Aragats to the north and Mount Ararat to the south. Of the two mountain peaks, the largest is Mount Ararat located in Turkey (fig. 1). The highest elevation in the Ararat Basin is in the northwest and the lowest elevation is in the southeast (fig. 2). The Aras River divides the Ararat Basin into northern and southern regions. The northern region is in Armenia and contains the study area (fig. 2), which was the focus area for the hydrogeologic framework, in part, because of the sparse well information in the southern region located in Turkey. In general, the thickest part of the basin is in the central part of the study area, with a thickness of approximately $220 \mathrm{~m}$. The shallowest part of the basin is in the southeastern part of the study area, with a thickness of approximately $15 \mathrm{~m}$.

The hydrogeologic framework of the Ararat Basin contains basin fill and interbedded geologic material consisting of dense clays, gravels, sands, volcanic basalts, and andesite deposits. A complete geologic history of the basin was described by the Armenian Branch of Mendez England and Associates (2014).
For this study, lithostratigraphic units were grouped into nine hydrogeologic units. The units were determined using published cross sections and well lithologic logs from annexes 2 and 3 of a study by the Armenian Branch of Mendez England and Associates (2014). The study described three water-bearing groundwater units, including one unconfined unit and two confined units. The confined units were under artesian conditions in some areas of the basin (Armenian Branch of Mendez England and Associates, 2014). For the nine units mapped in this report, four were identified as having a high water-bearing potential. These four units consisted of interbedded sands and gravels and fractured basalts (fig. 3).

\section{Data and Methods}

This section describes the data acquisition and analysis methods used to develop the hydrogeologic framework and to describe the groundwater conditions in the Ararat Basin. Data were available only for the northern region of the Ararat Basin in Armenia, which is hereafter referred to as the study area.

\section{Lithologic Data}

Lithologic data for the hydrogeologic framework were obtained from researchers from the ASPIRED program. ASPIRED researchers translated paper lithologic logs recorded in Russian language to Armenian and English for more than 2,500 wells completed in the study area. ASPIRED researchers provided the USGS with English descriptions of 24 unique lithologic layers (table 2). The water-bearing potential of each of the 24 unique lithologic layers (table 2) was determined based on interpretations of the English lithologic descriptions and with information summarized in annexes 2 and 3 in the Armenian Branch of Mendez England and Associates (2014) report.

Well top elevations provided by ASPIRED were corrected with a Landsat 30-m digital elevation model (DEM), available through the USGS EarthExplorer (https://earthexplorer.usgs.gov) website. The hydrogeologic unit thicknesses and the top and bottom elevations were then adjusted using the corrected well top elevations. The final corrected lithologic elevations were used to group the lithologic descriptions and map them with nine hydrogeologic units (fig. 3). 
Table 2. Lithologic descriptions, thickness, and water-bearing potential for 24 unique lithological materials based on lithologic logs for wells drilled in the Ararat Basin, Armenia.

[Descriptions and thickness statistics were based on lithologic data provided by the Advanced Science and Partnerships for Integrated Resource Development (ASPIRED) program (Lilith Harutyunyan, ASPIRED program, written commun., 2016)]

\begin{tabular}{|c|c|c|c|c|}
\hline \multirow{2}{*}{ Lithological description } & \multicolumn{3}{|c|}{ Thickness (meters) } & \multirow{2}{*}{$\begin{array}{c}\text { Water bearing } \\
\text { potential }^{1}\end{array}$} \\
\hline & Maximum & Minimum & Mean & \\
\hline Basalt with volcanic slag and sand & 82 & 1 & 23.7 & High. \\
\hline Boulder pebble deposits with coarse-grained sand filling & 93.2 & 4.5 & 29.1 & High. \\
\hline Boulder pebble deposits with sand-clay filling & 80 & 4 & 30.1 & High. \\
\hline Coarse-grained sand & 49.7 & 6 & 40.1 & High. \\
\hline Dense basalt andesite dacite & 61.6 & 0.5 & 21.5 & Low. \\
\hline Dense clay & 60 & 0.5 & 8.7 & Low. \\
\hline Fine-grained silty sand & 14.6 & 5.8 & 9.3 & High. \\
\hline Gravel pebble deposits with sand-clay filling & 89 & 6 & 39.3 & Moderate. \\
\hline Gravel sand & 89.5 & 4 & 38.7 & High. \\
\hline $\begin{array}{l}\text { Gypsiferous salt bearing clay with interbedded siltstone } \\
\text { marl and sandstone }\end{array}$ & 2 & 2 & 2.0 & Low. \\
\hline Highly fractured basalt & 147.8 & 0.2 & 35.6 & Moderate. \\
\hline Loam & 56 & 0.3 & 5.3 & Low. \\
\hline Loam sandy loam & 39.2 & 3 & 19.2 & Low. \\
\hline Poorly cemented sandstone & 11 & 6 & 7.4 & High. \\
\hline
\end{tabular}

${ }^{1}$ Interpretations were based on the generalized descriptions described in Armenian Branch of Mendez England and Associates (2014). 


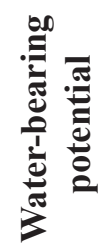

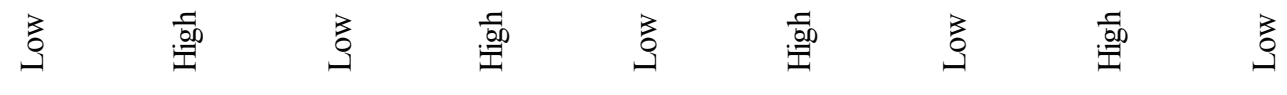
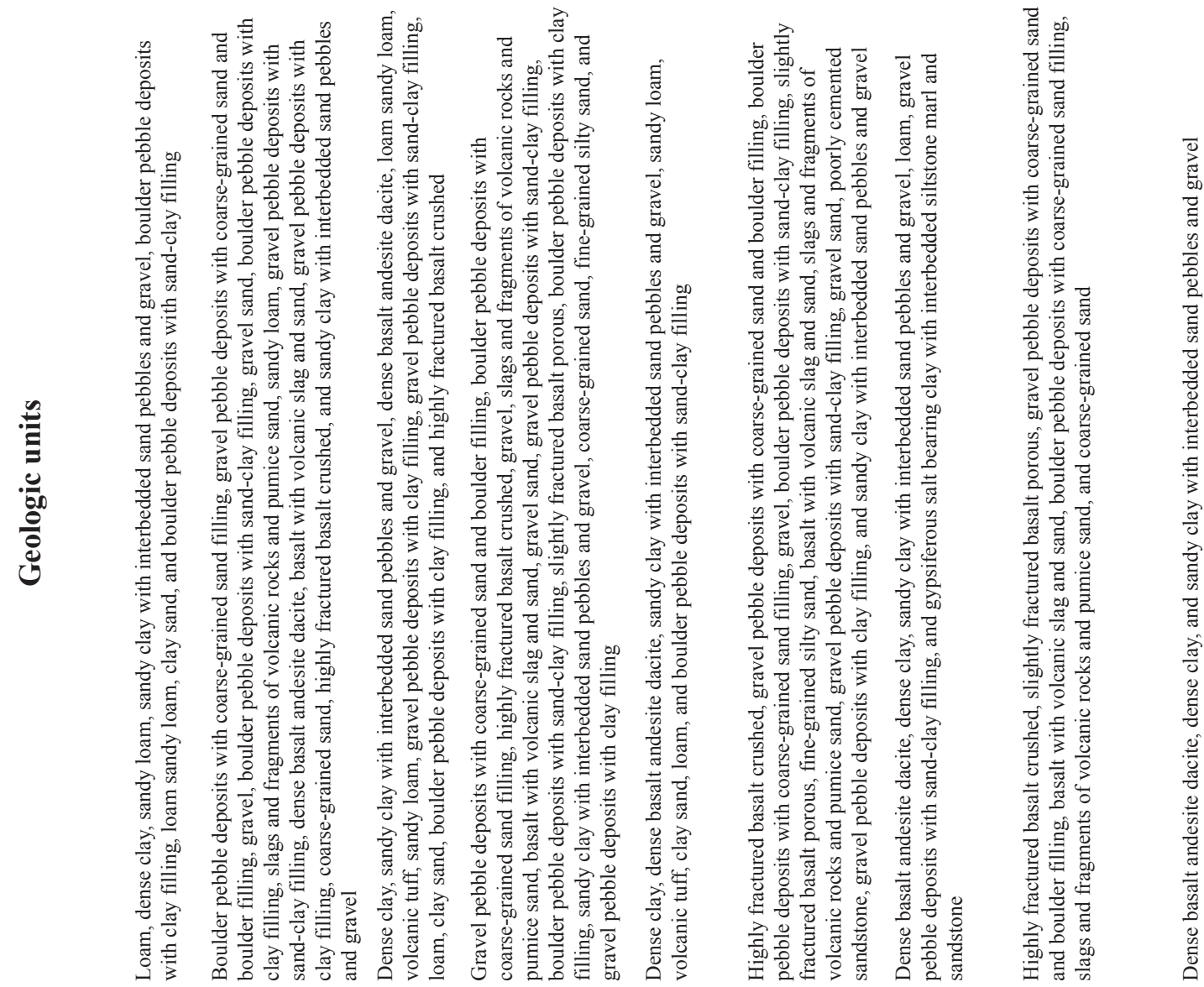

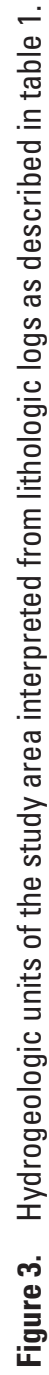


The unique lithologic layers were consolidated into nine hydrogeologic units based on lithologies and water-bearing potential. Of the 2,500 lithologic logs provided in English, 229 well logs were not used for the following reasons:

1. Lack of detail in lithologic descriptions, specifically for the upper or lower parts of the lithologic logs. Insufficient detail was determined by comparing the log to surrounding well logs and comparing the well descriptions, thicknesses, and well top elevations.

2. Overlapping descriptions, specifically descriptions that included several geologic units. Overlap problems were resolved by using well logs from surrounding wells.

3. Wells with land-surface elevation discrepancies. All the wells had a reported elevation in the database, which was assumed to approximate the land-surface elevation and compared with a 30-m DEM to verify elevation accuracies. In the entire lithologic database, 87 percent of the land-surface elevations that were reported differed from the DEM value by more than $1 \mathrm{~m}$. Only about 370 wells had the same value as the DEM value. Because of the large number of wells ( 87 percent) that did not match the DEM, a standard approach of removing wells that did not meet elevation requirements was applied systematically throughout the database. A well did not meet elevation requirements if its lithologic log top elevation differed by more than two standard deviations from the mean of 30-m DEM cells within a resampled 500-m grid square, which was used for interpolation. A well with a reported top elevation that varied more than two standard deviations from the mean was not included in the final database because of the uncertainty in the reported land-surface elevation at the well. A subset of wells was randomly selected and the well land-surface elevations were checked with land-surface elevations derived from Google Earth Pro (C 2016 Google) for verification.

Lithologic descriptions from each well log were correlated to the nine units and assigned a depth below the land surface. The depths were converted to elevation and each well's unit elevation was imported into a geographic information system (GIS). The elevation point data were used to create raster surfaces using the Esri topo-to-raster interpolation tool (Esri, 2017). The topo-to-raster method was chosen because the method optimizes the use of all the data points into a contoured topographic grid. Thickness rasters for each of the potential water-bearing units were created with the elevation rasters to compare aquifer volumes across the basin.

The volume of each unit was determined using a grid consisting of 157 rows and 232 columns and a cell size of $500 \mathrm{~m}$ by $500 \mathrm{~m}$. The volume estimates for the water-bearing units ranged from 38 to 72 cubic kilometers $\left(\mathrm{km}^{3}\right)$. The uppermost water-bearing gravel layer (hydrogeologic unit 2) consists of interbedded gravels; boulder pebble deposits with sand and clay filling; highly fractured basalts; and fragments of volcanic rocks, pumice, and sand. The total estimated volume for the first water-bearing unit (hydrogeologic unit 2) was $72 \mathrm{~km}^{3}$. The volumes of other water-bearing units were $61 \mathrm{~km}^{3}$ for hydrogeologic unit 4, $38 \mathrm{~km}^{3}$ for hydrogeologic unit 6 , and $53 \mathrm{~km}^{3}$ for the lowest water-bearing unit (hydrogeologic unit 8). The total volume of the entire basin (waterand nonwater-bearing units) was estimated as $366 \mathrm{~km}^{3}$.

\section{Hydrologic Data}

A USGS team provided in-country training to Armenian hydrology professionals in February-March 2016 in Yerevan, Armenia (Carter and others, 2016). Topics included groundwater modeling, well inventory, collection of water-level data, measuring well discharge, and water-quality sampling, including selected stable isotopes and cesium-137 for age-dating purposes. This training included classroom-style lectures in Yerevan and field training at selected sites visited in March 2016 (fig. 1). Sites included locations with flowing and nonflowing wells and surface-water features.

\section{Groundwater Data}

On March 2, 2016, field measurements were made at four well sites in the study area (fig. 1, table 3). Collected data included location, water level, well discharge, and notes describing site status. Field techniques were demonstrated using USGS field data collection protocols (Cunningham and Schalk, 2011) (fig. 4).

In 2016, using training provided by USGS, personnel from Hydrogeological Monitoring Center (under contract to the ASPIRED program) completed an inventory of wells in the study area. Data describing well status, water levels, and field water-quality constituents for more than 2,800 wells were collected. The data were provided to personnel from the ASPIRED program, who provided quality-assurance and project oversight on the well inventory. These data were provided by the ASPIRED program to the USGS. Data collected during the well inventory are provided in table 4 as a Microsoft ${ }^{\circ}$ Excel spreadsheet as a courtesy to readers.

Data collected during the well inventory for use in potentiometric surface maps were further checked by the USGS. The checking process determined that the land-surface elevations for more than 200 wells were inaccurate. These elevations were corrected using Google Earth Pro (C 2016 Google) and a 30-m DEM of the Ararat Basin. Only the corrected landsurface elevation data are provided in table 4. 
Table 3. Water-level and well discharge data collected in the Ararat Basin by U.S. Geological Survey in March 2016.

[Negative values for longitude indicate east of Prime Meridian. USGS, U.S. Geological Survey; WGS 84, World Geodetic System of 1984; ${ }^{\circ}$, degrees; ', minutes; ", seconds; L/s; liter per second; --, not applicable]

\begin{tabular}{|c|c|c|c|c|c|c|c|c|c|c|c|}
\hline 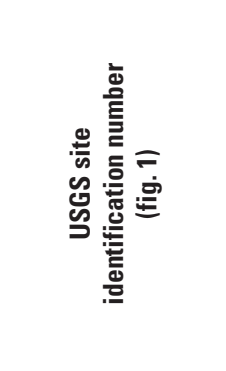 & 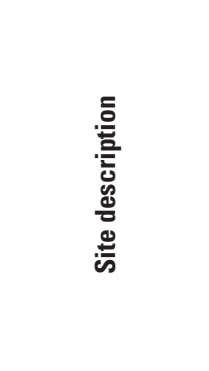 & 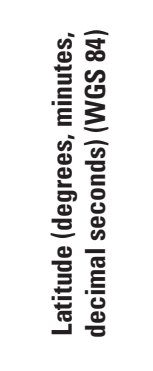 & 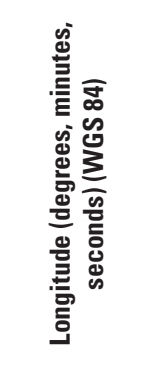 & 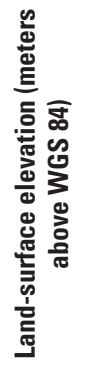 & 旁 & 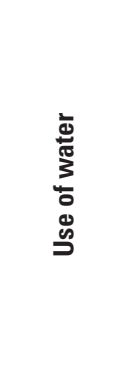 & 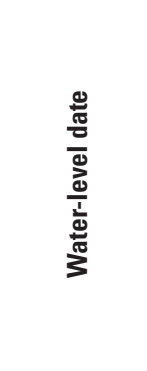 & 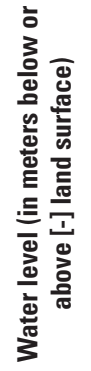 & 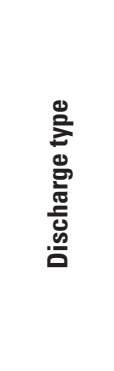 & 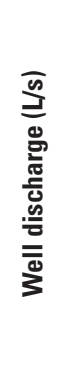 & \&્ڤ \\
\hline 394953044375601 & $\begin{array}{l}\text { Well near } \\
\text { Yeghegnavan, } \\
\text { Armenia } \\
\text { number } 1297\end{array}$ & $39^{\circ} 49^{\prime} 53.3^{\prime \prime}$ & $-44^{\circ} 37^{\prime} 55^{\prime \prime}$ & 817.8 & Observation & Unused & $03 / 02 / 2016$ & 5.47 & -- & -- & $\begin{array}{l}\text { Had been used } \\
\text { for irrigation } \\
\text { previously. }\end{array}$ \\
\hline 400250044235601 & $\begin{array}{l}\text { Well number } \\
1536 \text { near Sis, } \\
\text { Armenia }\end{array}$ & $40^{\circ} 02^{\prime} 49.9^{\prime \prime}$ & $-44^{\circ} 23^{\prime} 56^{\prime \prime}$ & 826.0 & Withdrawal & Waste & -- & -- & Flowing & 1.08 & $\begin{array}{l}\text { Flowing well } \\
\text { discharging } \\
\text { onto land } \\
\text { surface. }\end{array}$ \\
\hline 400347044223901 & $\begin{array}{l}\text { Well at Sis, } \\
\text { Armenia }\end{array}$ & $40^{\circ} 03^{\prime} 47.4^{\prime \prime}$ & $-44^{\circ} 22^{\prime} 39^{\prime \prime}$ & 831.8 & Withdrawal & -- & $03 / 02 / 2016$ & -2.74 & Flowing & 1.45 & -- \\
\hline
\end{tabular}

$\boldsymbol{A}$

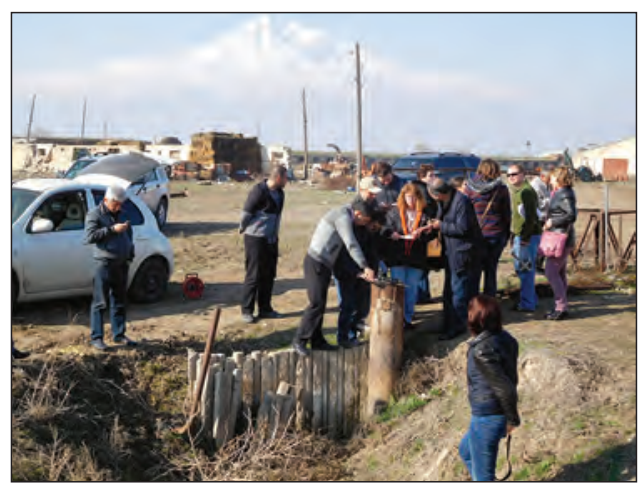

Figure 4. Collection of hydrologic data on March 2, 2016, as part of field training in Armenia. A, Collection of water-level data from a nonflowing well near Ararat, Armenia (U.S. Geological Survey site 394953044375601 ). $B$, Collection of water-level data from a flowing well near Masis, Armenia (U.S. Geological Survey site 400250044235601). C, Collection of well discharge data from a nonflowing well near Artashat, Armenia (U.S. Geological Survey site 395751044322601).
B

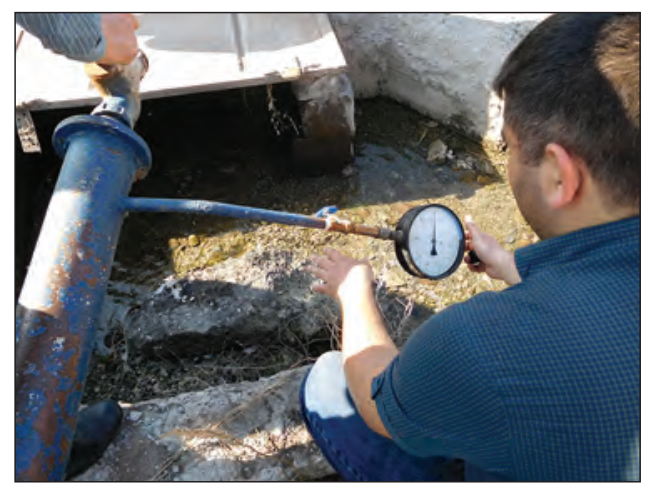

C

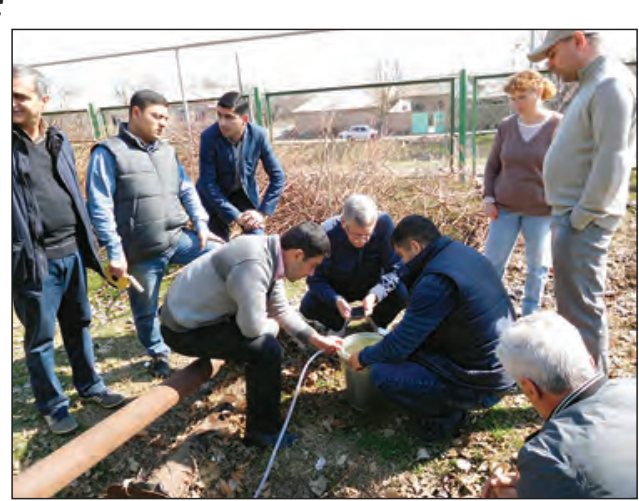


Table 4. Hydrologic data provided to the U.S. Geological Survey from the 2016 well inventory conducted in the Ararat Basin, Armenia, by Armenian partners (available online at https://doi.org/10.3133/sir20175163).

To determine groundwater-level changes with time, historical water-level data were acquired from ASPIRED researchers. The ASPIRED program provided a GIS file containing water-level data from 2007 for about 1,600 wells in the Ararat Basin. The data were digitized from two reports (in Armenian) by the Institute of Water Problems and Hydraulic Engineering after Academic Yeghiazarov of the Republic of Armenia (2007a, 2007b). The initial construction of a potentiometric surface map using the 2007 data indicated that land-surface elevations for more than 400 wells were not accurate. These elevations were corrected using Google Earth Pro (@ 2016 Google) and a 30-m DEM of the Ararat Basin. The 2007 water-level data are provided in table 5 as a Microsoft ${ }^{\circledR}$ Excel spreadsheet as a courtesy to readers. More than 1,000 additional wells are included in table 5 for which water-level data were not collected but for which the use of water was provided.

Table 5. Historical water-level data from 2007 in the Ararat Basin, Armenia, provided to the U.S. Geological Survey by Armenian partners (available online at https://doi.org/10.3133/ sir20175163).

Additional historical water-level data were obtained from annex 4 in Armenian Branch of Mendez England and Associates (2014). The report contained water-level data collected from 64 wells in the Ararat Basin from 1981 to 2013. The data from these 64 wells are provided in table 6 as a Microsoft ${ }^{\circledR}$ Excel spreadsheet as a courtesy to readers.

Table 6. Historical water-level and well yield data from various dates ranging from 1981 to 2013 in the Ararat Basin, Armenia (available online at https://doi.org/10.3133/sir20175163).

Potentiometric surface maps were constructed for four hydrogeologic units in the study area based on water-level data from the 2016 well inventory. Hydraulic heads were plotted for each of the hydrogeologic units and contoured at a 10-m interval. The contours were generalized and did not strictly follow hydraulic-head data to allow for smooth contour lines. Isolated hydraulic heads that caused "bull's-eyes" in the contours were ignored because they were determined to be either within the margin of error for the contour interval or they were assumed to be based on incorrect water-level measurements.

\section{Water-Quality Data}

On March 2, 2016, four wells and one stream site in the Ararat Basin were measured for field water-quality constituents (fig. 1). Water temperature and specific conductance were measured using data collection protocols as described by U.S. Geological Survey (variously dated). In addition to field water-quality measurements, samples were collected at selected sites for analyses of stable isotopes of hydrogen and oxygen. Field water-quality measurements and results of laboratory analyses of samples collected by the USGS during the field training are presented in table 7.

Stable isotopes of hydrogen (deuterium $\left[{ }^{2} \mathrm{H}\right]$ and protium $\left.\left[{ }^{1} \mathrm{H}\right]\right)$ and oxygen $\left({ }^{18} \mathrm{O}\right.$ and $\left.{ }^{16} \mathrm{O}\right)$ are used to evaluate recharge areas and groundwater flow paths. Stable isotope values are given in "delta notation," which compares the ratio between heavy and light isotopes of a sample to that of a reference standard. Delta $(\delta)$ values are expressed as a difference, in per mil, from value reference standard (Révész and Coplen, 2008a). Samples for analyses of stable isotopes were collected according to USGS methods (Reston Stable Isotope Laboratory, 2016). Glass bottles (60-milliliter) for stable isotope samples (fig. 5) were filled two-thirds full to prevent freezethaw breakage. Bottles were then sealed with a polyseal cap. Sample bottles were stored at room temperature and shipped to the USGS's Reston Stable Isotope Laboratory in Reston, Virginia, for analyses by methods described in Révész and Coplen (2008a, 2008b).

As part of the well inventory completed in 2016, personnel from the Hydrogeological Monitoring Center (under contract to the ASPIRED program) measured specific conductance and temperature in well water using USGS protocols (U.S. Geological Survey, variously dated). The specific conductance and temperature data were included in the hydrological data provided to the USGS (table 4). Personnel from the Hydrogeological Monitoring Center also collected waterquality data on mineralization, which represents a sum of concentration of seven ions (calcium, magnesium, potassium, sodium, chloride, sulfate, and bicarbonate) in a water sample. The method used for measuring mineralization is not known, but the data are included in table 4 .

\section{Hydrogeologic Framework}

The groundwater resources and general geologic characteristics of the Ararat Basin are described by Armenian Branch of Mendez England and Associates (2014). That report includes groundwater trends over time and estimated flows in and out of the Ararat Basin; however, groundwater discharge into rivers was not measured and discharge numbers remain unknown. It is clear, however, that the groundwater discharge component is an important part of groundwater balance because the Metsamor River, for example, is recharged (fed) exclusively by groundwater. In 2016, a well inventory was completed by the Armenian Branch of Mendez England and Associates to further define and characterize the hydrogeology in and around the Ararat Basin. The inventory included approximately 2,800 wells completed in and around the Ararat Basin. The inventory's goal was to further characterize the 
Table 7. Water-quality data collected or analyzed by U.S. Geological Survey in March 2016 in the Ararat Basin, Armenia.

[Negative values for longitude indicate east of Prime Meridian. USGS, U.S. Geological Survey; WGS 84, World Geodetic System of 1984; ${ }^{\circ}$, degrees; ', minutes; ", seconds; $\mu \mathrm{S} / \mathrm{cm}$; microsiemens per centimeter; $\delta^{2} \mathrm{H}$, stable isotope ratio of hydrogen-2 to hydrogen-1; $\delta^{18} \mathrm{O}$ stable isotope ratio of oxygen-18 to oxygen-16; --, not applicable]

\begin{tabular}{|c|c|c|c|c|c|c|c|c|}
\hline $\begin{array}{c}\text { USGS site } \\
\text { identification } \\
\text { number }\end{array}$ & Site description & $\begin{array}{l}\text { Latitude } \\
\text { (degrees, } \\
\text { minutes, } \\
\text { decimal } \\
\text { seconds) } \\
\text { (WGS 84) }\end{array}$ & $\begin{array}{l}\text { Longitude } \\
\text { (degrees, } \\
\text { minutes, } \\
\text { seconds) } \\
\text { (WGS 84) }\end{array}$ & $\begin{array}{c}\text { Sample } \\
\text { collection } \\
\text { date }\end{array}$ & $\begin{array}{c}\text { Specific } \\
\text { conduc- } \\
\text { tance } \\
(\mu \mathrm{S} / \mathrm{cm})\end{array}$ & $\begin{array}{c}\text { Water tem- } \\
\text { perature } \\
\text { (degrees } \\
\text { Celsius) }\end{array}$ & $\begin{array}{c}\delta^{2} \mathrm{H} \\
\text { (per mil) }\end{array}$ & $\begin{array}{c}\delta^{18} \mathrm{O} \\
\text { (per mil) }\end{array}$ \\
\hline 394953044375601 & $\begin{array}{l}\text { Well near Yeghegnavan, } \\
\text { Armenia number } 1297\end{array}$ & $39^{\circ} 49^{\prime} 53.3^{\prime \prime}$ & $-44^{\circ} 37^{\prime} 55^{\prime \prime}$ & $03 / 02 / 2016$ & 615 & 15.6 & -72.70 & -10.84 \\
\hline 400250044235601 & $\begin{array}{l}\text { Well number } 1536 \text { near } \\
\text { Sis, Armenia }\end{array}$ & $40^{\circ} 02^{\prime} 49.9^{\prime \prime}$ & $-44^{\circ} 23^{\prime} 56^{\prime \prime}$ & $03 / 02 / 2016$ & 841 & 16.9 & -69.50 & -10.33 \\
\hline 400347044223901 & Well at Sis, Armenia & $40^{\circ} 03^{\prime} 47.4^{\prime \prime}$ & $-44^{\circ} 22^{\prime} 39^{\prime \prime}$ & $03 / 02 / 2016$ & 692 & 15.2 & -70.90 & -10.68 \\
\hline 401110044295401 & $\begin{array}{l}\text { Hrazdan River at } \\
\text { Yerevan, Armenia }\end{array}$ & $40^{\circ} 11^{\prime} 10.0^{\prime \prime}$ & $-44^{\circ} 29^{\prime} 54^{\prime \prime \prime}$ & $03 / 02 / 2016$ & -- & -- & -71.60 & -10.58 \\
\hline
\end{tabular}

lithology, water levels, and additional hydrologic properties. The 2016 well inventory was used to supplement and update previously published groundwater data. Additionally, the 2016 inventory permitted calculation of groundwater trends and aquifer response to stresses. These stresses could include pumping, climatic variations, and changes in water use and land use in the Ararat Basin. This section describes in more detail the Ararat Basin lithology of the area, the various hydrogeologic units, and the areal extent of the basin.

\section{Areal Extent}

The Ararat Basin is in southern Armenia and northern parts of Turkey (fig. 1). The basin is a depression valley filled with a complex geologic network of buried ancient river channels covered by volcanic tuff and basalts. Additionally, modern alluvial deposits from several rivers in the basin, including the Aras River and its tributaries (Armenian Branch of Mendez England and Associates, 2014), fill the basin. The northern region of the Ararat Basin in Armenia extends north of the Aras River. The basin's area is about $1,300 \mathrm{~km}^{2}$ with elevations ranging from 800 to $1,000 \mathrm{~m}$ above sea level (Armenian Branch of Mendez England and Associates, 2014). The basin is approximately 110 kilometers $(\mathrm{km})$ from west to east and from about 5 to $30 \mathrm{~km}$ north to south (fig. 1).

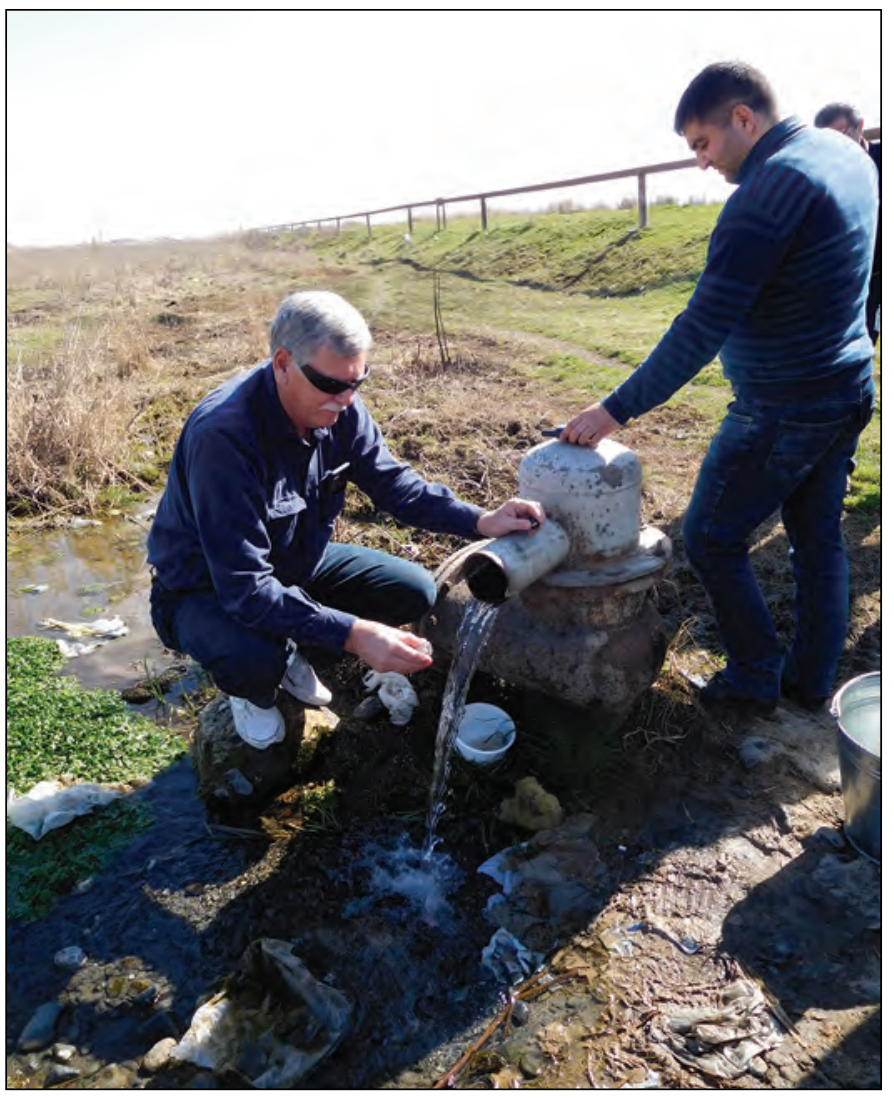

Figure 5. Collection of stable-isotope sample from a flowing well (U.S. Geological Survey site 400250044235601) in the Ararat Basin, Armenia. 


\section{Hydrogeologic Units}

The Ararat Basin surficial geology is dominated by alluvial deposits overlying several water and nonwater-bearing units. The Armenian Branch of Mendez England and Associates (2014) published an extensive study of the groundwater and descriptions of several hydrogeologic formations that make up the Ararat Basin. USAID, in cooperation with the Armenian Branch of Mendez England and Associates (2014), described a hydrogeology of complex inner layering of sandstones and igneous rock types (fig. 3). From these sources and recent well lithological information, nine hydrogeologic units were identified in the Ararat Basin study area (fig. 6). The study area was divided into three subregions (Western, Central, and Eastern) for purposes of describing the lithology, thicknesses, and density of wells that defined the units (fig. 7). The subregions were separated using rivers that flowed north to south. The subregions (fig. 7), nine hydrogeologic units, and lithologic characteristics and descriptions (fig. 3) that constitute each of the units are described in the following subsections.

\section{Hydrogeologic Unit 1}

The uppermost hydrogeologic unit (unit 1) consists primarily of loam, dense clay, and sandy loam. The unit is characterized mostly by loam, which makes up about 66 percent of the geologic unit. Sandy loam and a dense clay layer make up the other 25 percent (12 percent and 13 percent, respectively). The remaining geologic material includes boulder pebble deposits with clay filling (1 percent), loam sandy loam (1 percent), and sand and fragments of volcanic rocks and pumice sand (7 percent). Lithologic logs from 2,301 wells were used to define unit 1, and spatially these wells covered most of the study area (fig. 8). Unit 1 had the third highest number of wells drilled into the unit when compared to all other unit descriptions and lithologic logs (table 8). Unit 1 was the thinnest when compared to the other 8 units, with a mean thickness of $8 \mathrm{~m}$. The maximum measured thickness, determined from lithologic logs, was $51 \mathrm{~m}$. The maximum interpolated thickness was $84 \mathrm{~m}$. The interpolated thickness is higher along the unit's northern border because it includes topographically high areas along the perimeter of the study area and few lithologic logs (fig. 9).

\section{Hydrogeologic Unit 2}

Underlying unit 1 is the uppermost water-bearing unit, unit 2, consisting primarily of boulder pebble deposits with coarse-grained sand filling, gravel pebble deposits with coarse-grained sand and boulder filling, and gravels. About 42 percent of the hydrogeologic unit is boulder pebble deposits. Gravel pebble deposits with coarse-grained sand and boulder filling and gravels make up the other 38 percent (28 percent and 10 percent, respectively). The remaining geologic material includes basalt with volcanic slag and sand (1 percent), boulder pebble deposits with clay filling (3 percent), boulder pebble deposits with sand-clay filling (7 percent), dense basalt andesite dacite (1 percent), gravel pebble deposits with clay filling (1 percent), gravel pebble deposits with sand-clay filling (1 percent), gravel sand (3 percent), sandy loam (1 percent), and slags and fragments of volcanic rocks and pumice sand (2 percent). Lithologic $\operatorname{logs}$ from 2,483 wells were used to define unit 2 (fig. 8). Spatially, the wells covered most of the study area with the higher density of wells in the south central part of the basin (fig. 7). Unit 2 had the greatest number of wells drilled into the unit compared to other units (table 8). Unit 2 was the thickest unit with a mean thickness of $32 \mathrm{~m}$. The maximum measured thickness, determined from lithologic logs, was $89 \mathrm{~m}$. Unit 2 was the thinnest measured and interpolated water-bearing unit (table 8). The maximum interpolated thickness was $84 \mathrm{~m}$. The thickest part of the unit, based on the interpolated values, was in the western and central subregion where most of the wells drilled into the unit were located (figs. 7, 9).

\section{Hydrogeologic Unit 3}

Unit 3 underlies unit 2 and is a nonwater-bearing unit (confining layer). It consists of dense clay, sandy clay with interbedded sand pebbles and gravel, and dense basalt andesite dacite. The unit was characterized mostly by dense clays that constitute about 69 percent of the geologic unit. Sandy clay with interbedded sand pebbles and gravel and dense basalt andesite dacite make up the other 18 percent (11 percent and 7 percent, respectively). The remaining geologic material includes boulder pebble deposits with clay filling (1 percent), clay sand (1 percent), gravel pebble deposits with clay filling (1 percent), gravel pebble deposits with sandclay filling (1 percent), highly fractured basalt (1 percent), loam (1 percent), loam sandy loam (4 percent), sandy loam ( 2 percent), and volcanic tuff ( 3 percent). Lithologic logs from 2,242 wells were used to define unit 3 (fig. 8) and spatially these wells covered most of the basin, with a higher density of wells in the south-central part of the basin (fig. 7). Unit 3 ranked fourth in the total number of wells drilled into the unit (table 8). The mean thickness of the unit was $14 \mathrm{~m}$ and the maximum measured thickness, determined from lithologic logs, was $62 \mathrm{~m}$. The maximum interpolated thickness was $83 \mathrm{~m}$ (table 8). The thickest part of the unit, based on the interpolated values, was in the western subregion (figs. 7, 9). 

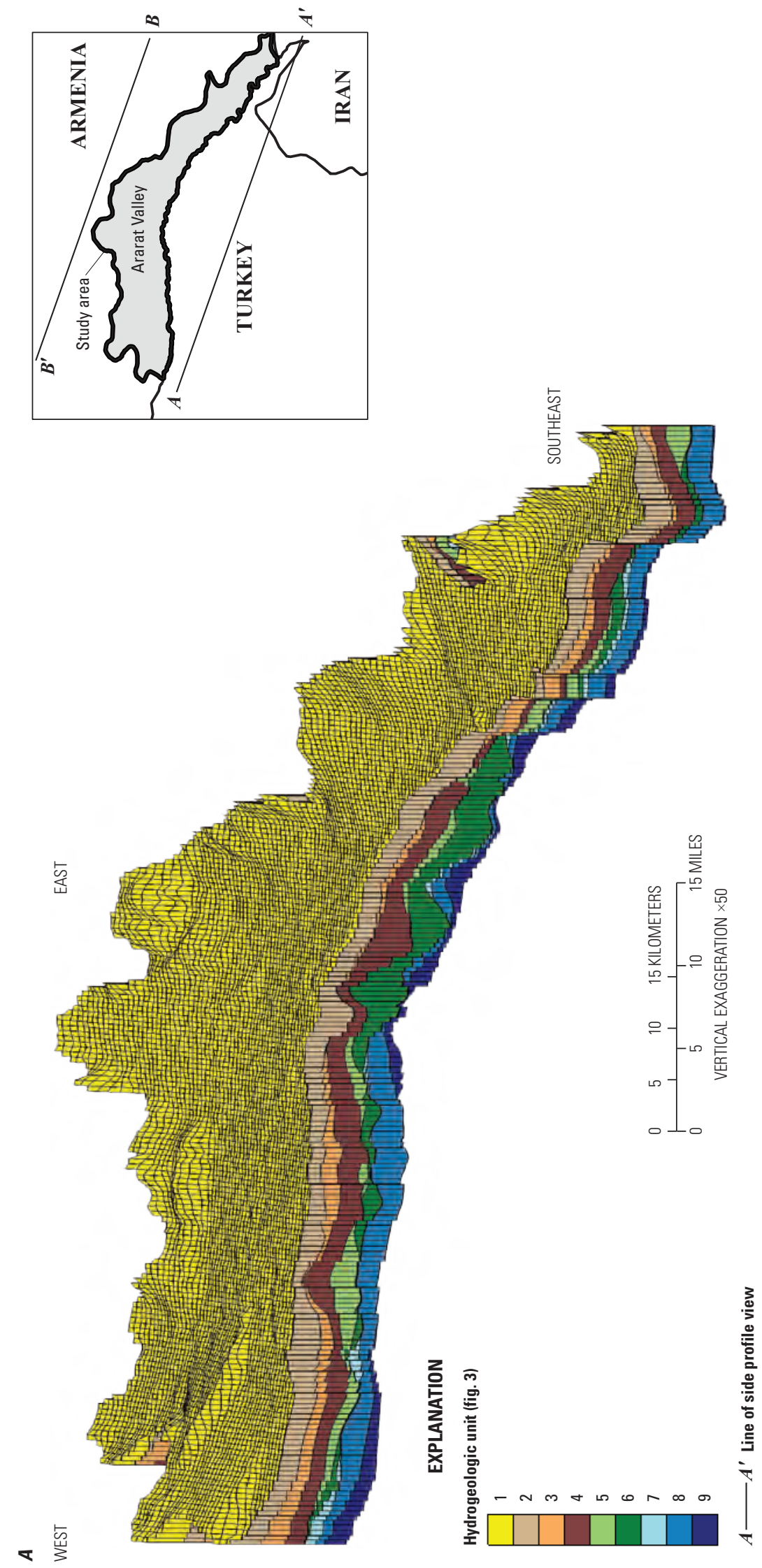

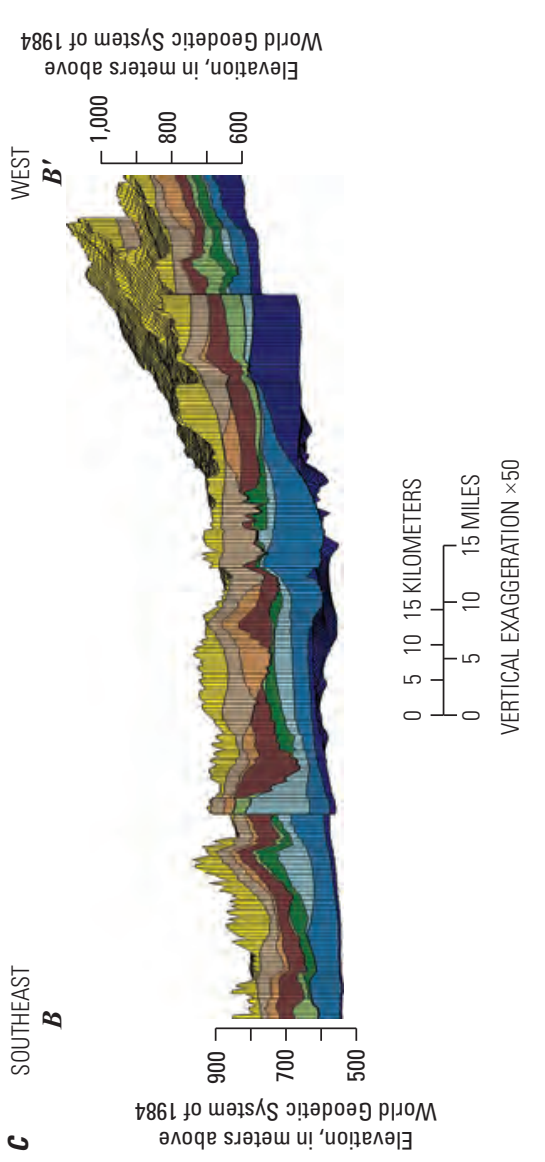

힝

ᄒ웡

트

훈

을 익

क्ष

든

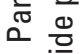

둥

芯

屯

它

홍요

䓠

空 은

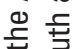

흐요

흥

을

흘.

空

은 은

응 흠

至

혼

我

के

힝 음

䨔

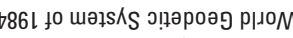

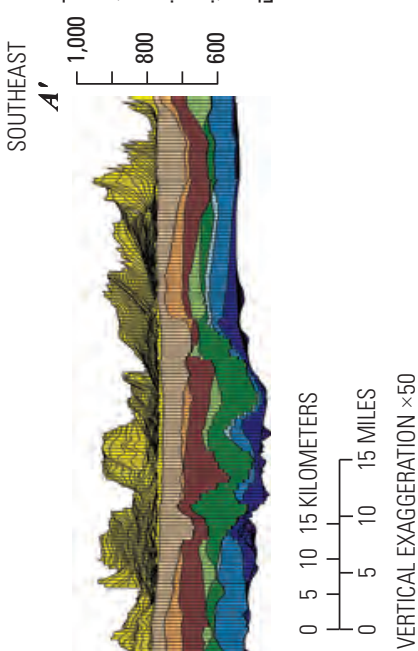

这尔

站

品

त范

훈

힌

范

흘 즘

एँㅣㄹ

흔 힐

흘

. 일

के

등

은 흠

范

हू 음

ఏํㅣ응

这

(1)

잉

홍ㅎㅀ 응 


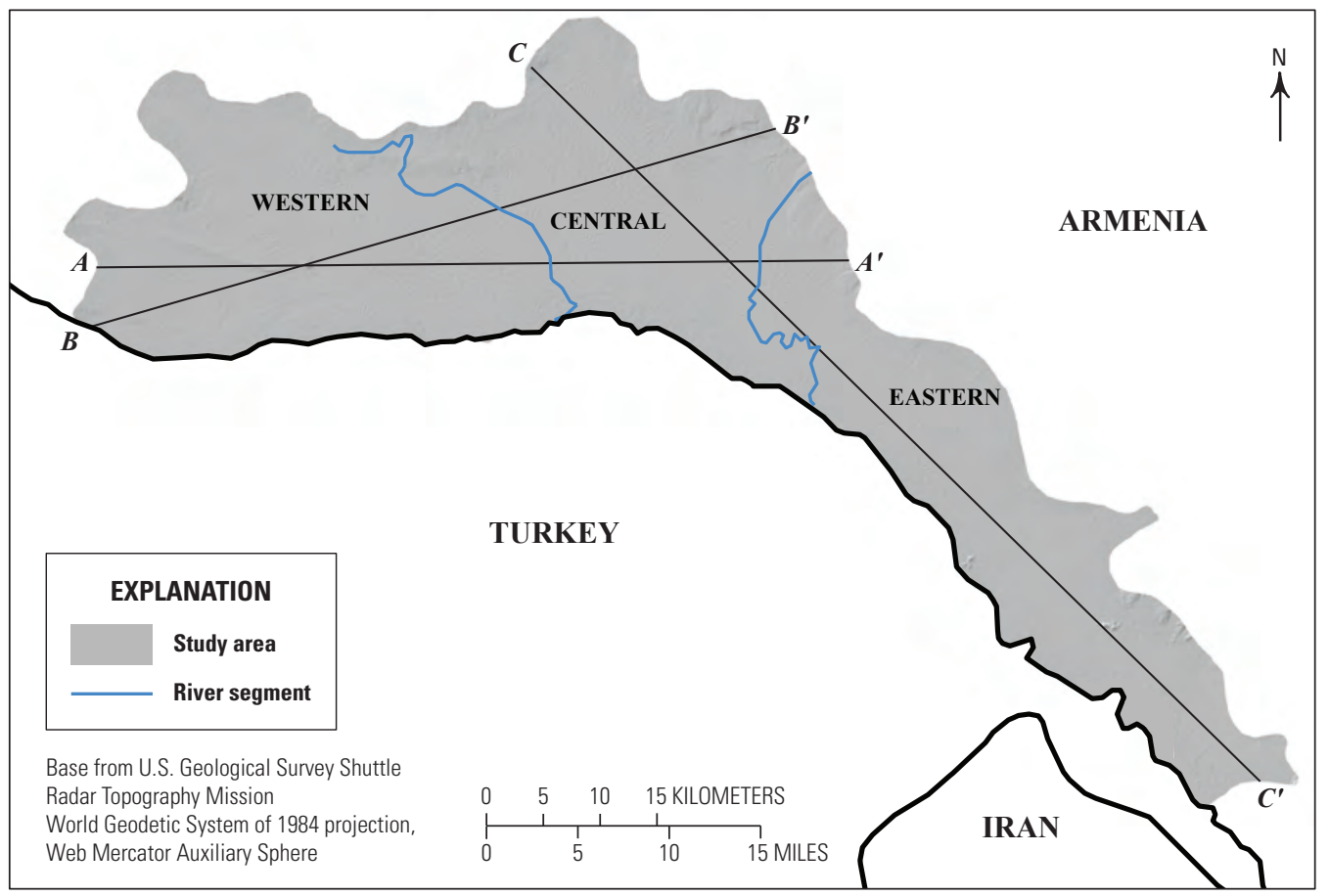

\section{EXPLANATION}

Hydrogeologic unit (fig. 3)
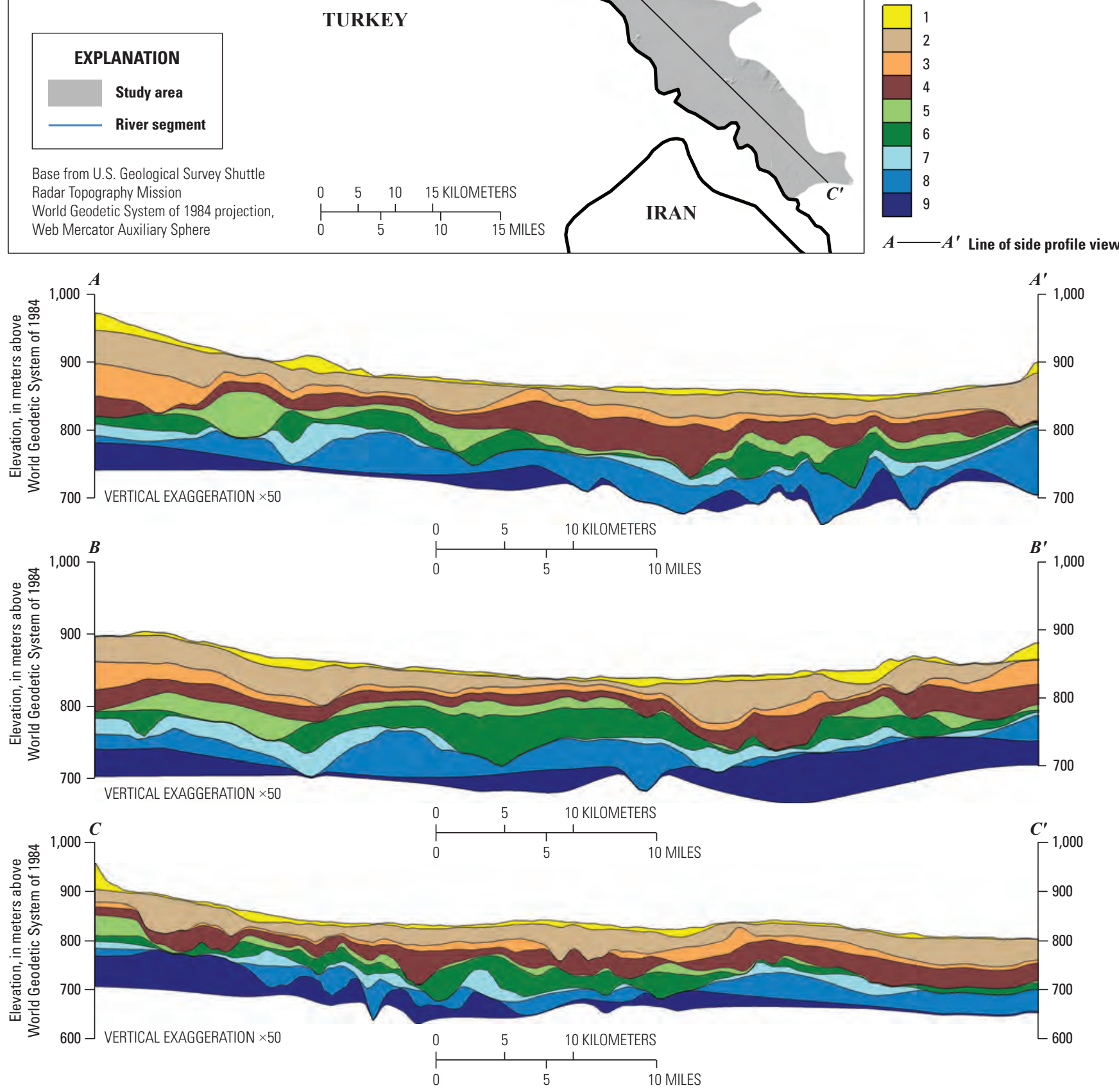

Figure 7. Map of three subbasin areas and three cross sections of the Ararat Basin, Armenia, used to define the nine hydrogeologic units. 

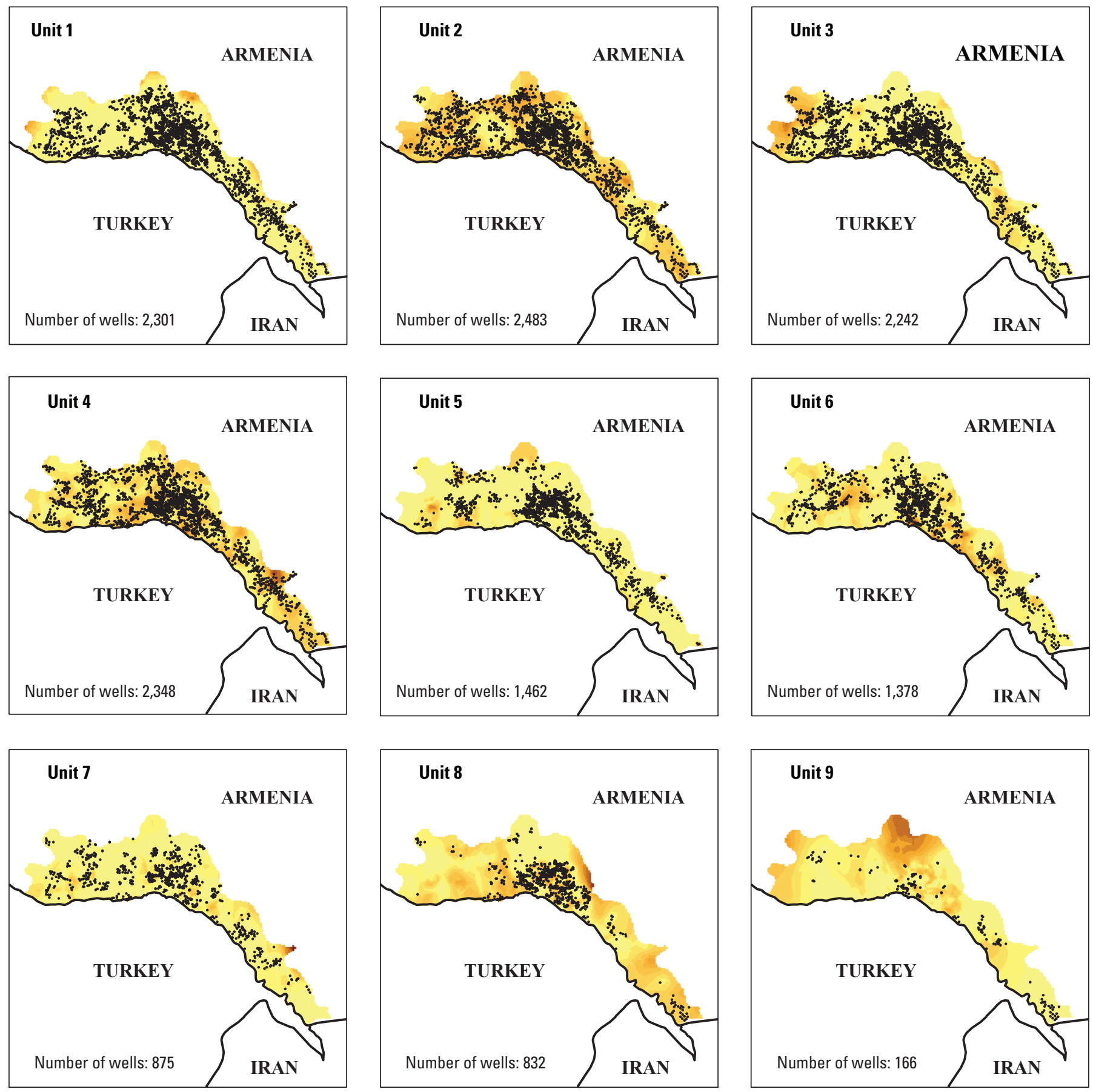

Base from U.S. Geological Surve

World Geodetic System of 1984 projection,

Web Mercator Auxiliary Sphere

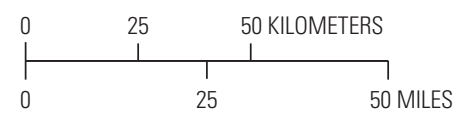

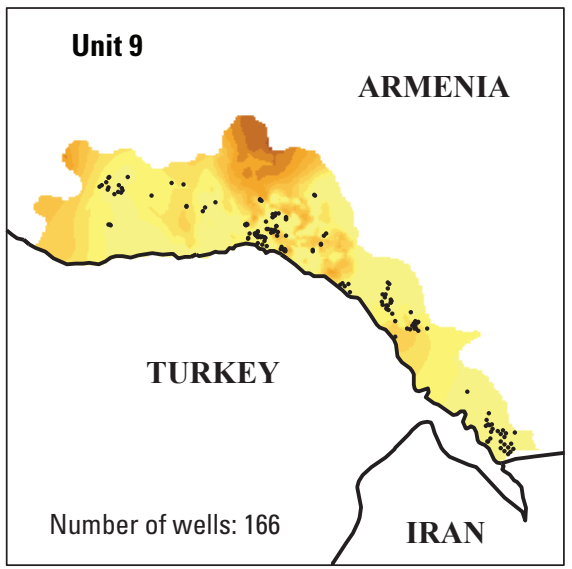

EXPLANATION

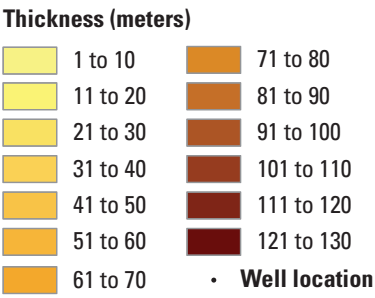

Figure 8. Number and distribution of wells used to generate thicknesses for each of the nine hydrogeologic units in the Ararat Basin, Armenia. 

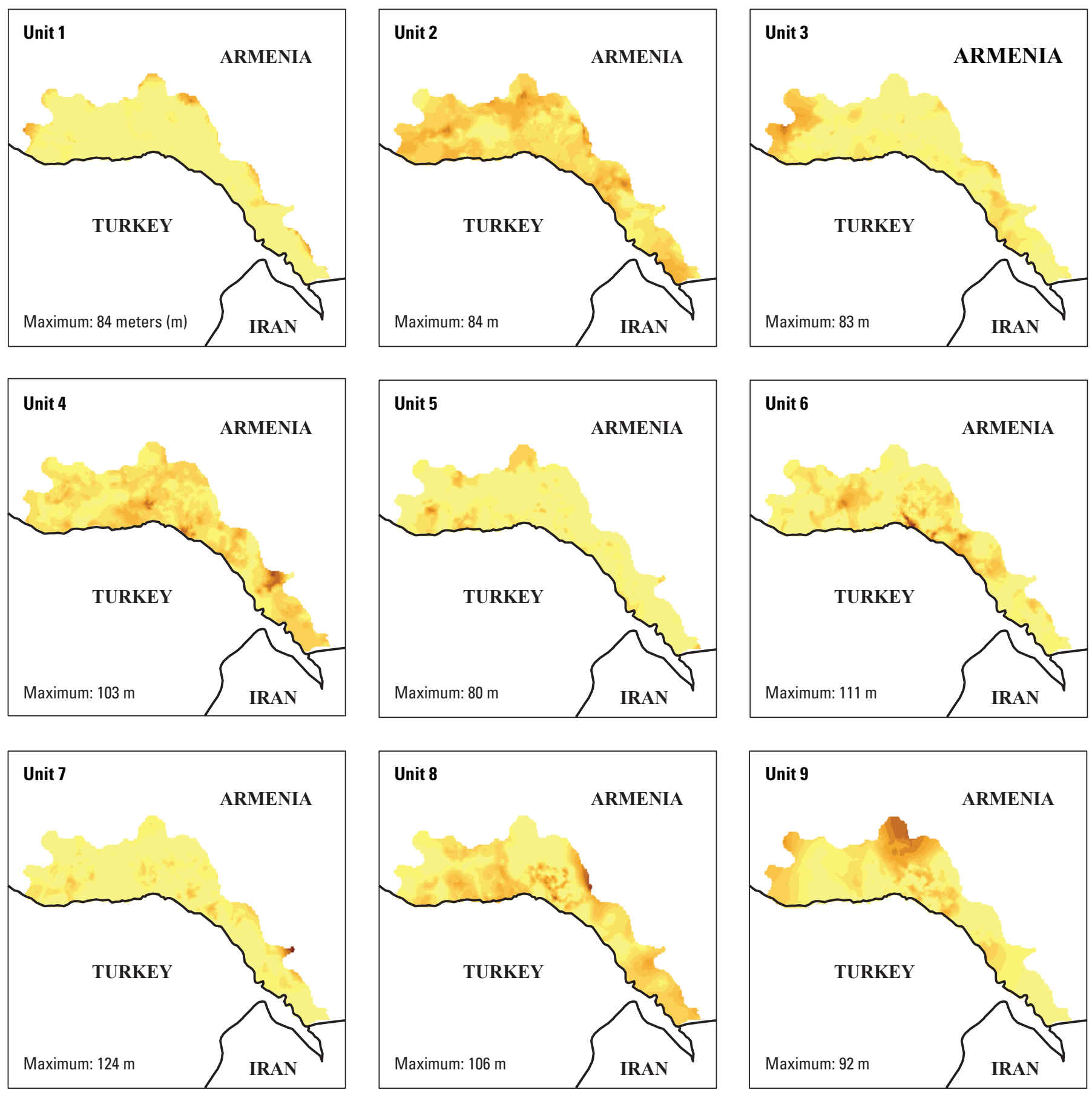

Base from U.S. Geological Survey

World Geodetic System of 1984 projection,

Web Mercator Auxiliary Sphere
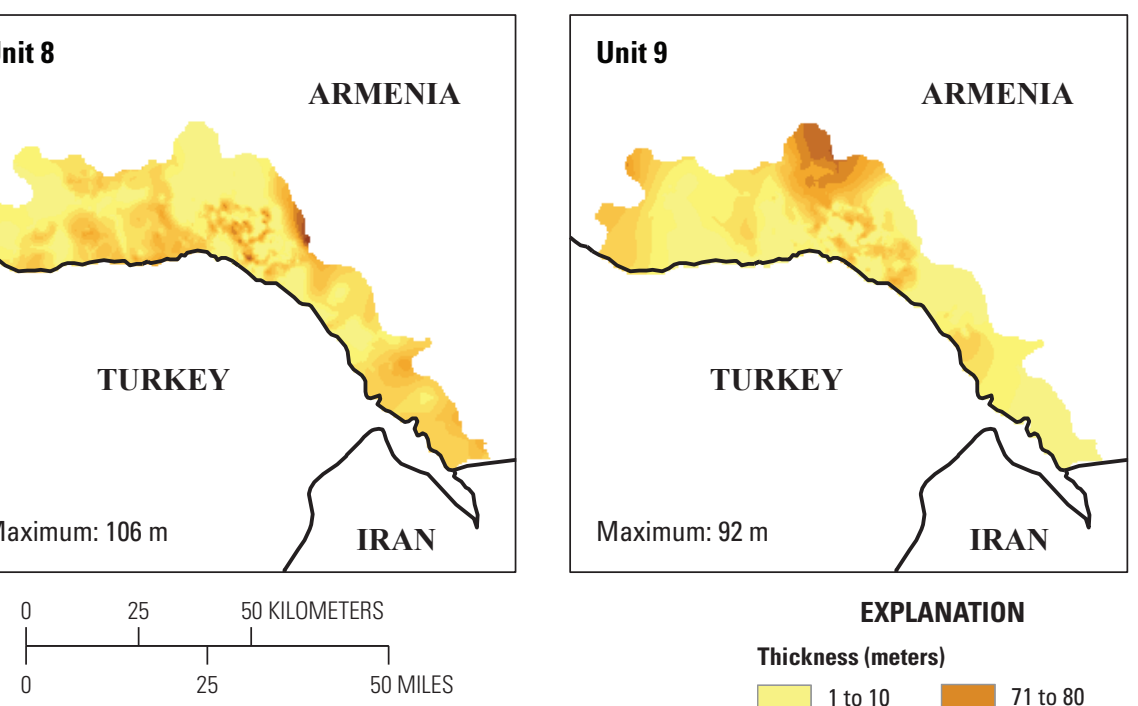

EXPLANATION

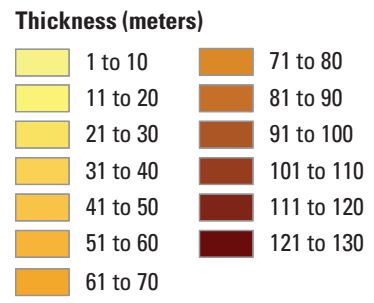

Figure 9. Thickness of all nine hydrogeologic units in the Ararat Basin, Armenia. 
Table 8. Summary of each unit detailing the number of wells used in defining the geologic material, the average unit thickness across the Ararat Basin, and the maximum measured and interpolated thicknesses within each of the hydrogeologic units.

\begin{tabular}{|c|c|c|c|c|c|}
\hline Unit number & Primary geological material & $\begin{array}{l}\text { Number of wells } \\
\text { drilled into the unit }\end{array}$ & $\begin{array}{l}\text { Average unit } \\
\text { thickness } \\
\text { (meters) }\end{array}$ & $\begin{array}{l}\text { Maximum measured } \\
\text { thickness within unit } \\
\text { (meters) }\end{array}$ & $\begin{array}{l}\text { Maximum interpolated } \\
\text { thickness within unit } \\
\text { (meters) }\end{array}$ \\
\hline 1 & Loam & 2,301 & 8 & 51 & 84 \\
\hline 2 & Boulder pebble deposits & 2,483 & 32 & 89 & 84 \\
\hline 3 & Dense clay & 2,242 & 14 & 62 & 83 \\
\hline 4 & $\begin{array}{l}\text { Gravel pebble deposits with } \\
\text { coarse-grained sand and } \\
\text { boulder filling }\end{array}$ & 2,348 & 27 & 110 & 103 \\
\hline 5 & Dense clay & 1,462 & 9 & 73 & 80 \\
\hline 6 & Highly fractured basalt & 1,378 & 17 & 148 & 111 \\
\hline 7 & Dense basalt andesite dacite & 875 & 10 & 60 & 124 \\
\hline 8 & Highly fractured basalt & 832 & 23 & 119 & 106 \\
\hline
\end{tabular}

\section{Hydrogeologic Unit 4}

Unit 4 underlies unit 3 and is the second water-bearing unit. Unit 4 consists primarily of gravel pebble deposits with coarse-grained sand and boulder filling, boulder pebble deposits with coarse-grained sand filling, and gravel. The unit is characterized mostly by gravel pebble deposits with coarse-grained sand and boulder filling, which make up about 35 percent of the geologic unit. Boulder pebble deposits with coarse-grained sand filling and gravel make up the other 41 percent ( 34 percent and 7 percent, respectively). The remaining geologic material includes basalt with volcanic slag and sand ( 3 percent), boulder pebble deposits with clay filling (1 percent), boulder pebble deposits with sand-clay filling ( 2 percent), gravel pebble deposits with sand-clay filling ( 2 percent), gravel sand ( 3 percent), highly fractured basalt (9 percent), sandy clay with interbedded sand pebbles and gravel (1 percent), slags and fragments of volcanic rocks and pumice sand ( 3 percent), and slightly fractured porous basalt (1 percent). Lithologic logs from 2,348 wells were used to define unit 4 (fig. 8; table 8) and spatially these wells covered most of the basin with a higher density of wells in the southcentral part of the basin (fig. 7). Unit 4 had the second largest number of wells drilled into the unit (table 8). The mean thickness of the entire unit was $27 \mathrm{~m}$ and the maximum measured thickness, determined from lithologic logs, was $110 \mathrm{~m}$. The maximum interpolated thickness was $103 \mathrm{~m}$ (table 8). The thickest part of the unit, based on the interpolated values, was in the central and eastern subregions of the basin (figs. 7, 9).

\section{Hydrogeologic Unit 5}

Underlying unit 4 is a nonwater-bearing unit (confining layer), unit 5 , consisting primarily of dense clay, dense basalt andesite dacite, and sandy clay with interbedded sand pebbles and gravel. The unit is characterized by dense clay, which makes up about 68 percent of the geologic unit. Dense basalt andesite dacite and sandy clay with interbedded sand pebbles and gravel make up the other 23 percent (12 percent and 11 percent, respectively). The remaining geologic material includes clay sand (1 percent), sandy loam (4 percent), and volcanic tuff ( 3 percent). Lithologic logs from 1,462 wells were used to define unit 5 (fig. 8). The western part of the study area had few lithologic logs available to define the geologic unit (fig. 7). The south-central and eastern subregions of the study area have a higher density of wells than the western subregion (fig. 8). Unit 5 ranked fifth in the total number of wells drilled into the unit in the study area (table 8). The mean thickness of the unit was $9 \mathrm{~m}$ (the second thinnest unit). The maximum measured thickness, determined from lithologic logs, was $73 \mathrm{~m}$. The maximum interpolated thickness was $80 \mathrm{~m}$ (table 8 ). The thickest part of this unit, based on the interpolated values, was in the central and western subregions of the basin (figs. 7, 9). 


\section{Hydrogeologic Unit 6}

Underlying unit 5 is the third water-bearing unit, unit 6, which consists primarily of highly fractured basalt, gravel pebble deposits with coarse-grained sand and boulder filling, and boulder pebble deposits with coarse-grained sand filling. The unit is characterized mostly by highly fractured basalt, which makes up about 43 percent of the geologic unit. Gravel pebble deposits with coarse-grained sand and boulder filling and boulder pebble deposits with coarse-grained sand filling make up the other 21 percent (12 percent and 9 percent, respectively). The remaining geologic material includes basalt with volcanic slag and sand (5 percent), boulder pebble deposits with sand-clay filling (7 percent), fine-grained silty sand (6 percent), gravel ( 9 percent), gravel pebble deposits with sand-clay filling (1 percent), gravel sand (1 percent), poorly cemented sandstone (1 percent), slags and fragments of volcanic rocks and pumice sand (1 percent), and slightly fractured porous basalt ( 6 percent). Lithologic logs from 1,378 wells were used to define unit 6 (fig. 8). There were few lithologic logs in the southwestern part of the study area available to define the geologic unit. More wells were available in the southern part of the central subregion and in the eastern subregion of the basin (fig. 7). Unit 6 ranked sixth in the total number of wells drilled into the unit (table 8). The mean thickness of the unit was $17 \mathrm{~m}$ and the maximum measured thickness, determined from lithologic logs, was $148 \mathrm{~m}$. The maximum interpolated thickness was $111 \mathrm{~m}$ (table 8). The thickest part of the unit, based on the interpolated values, was in the south-central part of the central subregion and northern part of the eastern subregion (figs. 7, 9).

\section{Hydrogeologic Unit 7}

Underlying unit 6 is a nonwater-bearing unit (confining layer), unit 7 , which consists primarily of dense basalt andesite dacite, dense clay, and sandy clay with interbedded sand pebbles and gravel. The unit is characterized mostly by dense basalt andesite dacite, which makes up about 48 percent of the geologic unit. Dense clay and sandy clay with interbedded sand pebbles and gravel made up the other 49 percent (37 percent and 12 percent, respectively). The remaining geologic material included gravel pebble deposits with sandclay filling (1 percent) and loam (1 percent). Lithologic logs from 875 wells were used to define unit 7 (fig. 8). Although fewer wells were used to define the unit than the six previously described units, spatially the wells covered most of the study area. The central subregion had the higher density of wells than the other subregions (fig. 7). Unit 7 ranked seventh in the total number of wells drilled into the unit (table 8). The mean thickness of the entire unit was $10 \mathrm{~m}$ and the maximum measured thickness, determined from lithologic logs, was $60 \mathrm{~m}$. The maximum interpolated thickness was $124 \mathrm{~m}$ (table 8). The thickest part of the unit, based on the interpolated values, was in the eastern subregion of the basin (fig. 9). The maximum interpolated thickness of unit 7 is greater than the measured thickness likely because it includes topographically high areas along the perimeter of the basin and because of the limited spatial distribution of available lithologic information.

\section{Hydrogeologic Unit 8}

Underlying unit 7 is the fourth water-bearing unit, unit 8 , which consists primarily of highly fractured basalt, slightly fractured porous basalt, and gravel pebble deposits with coarse-grained sand and boulder filling. The unit is characterized mostly by highly fractured basalt, which makes up about 68 percent of the geologic unit. Slightly fractured porous basalt and gravel pebble deposits with coarse-grained sand and boulder filling make up the other 19 percent (13 percent and 6 percent, respectively). The remaining geologic material included basalts with volcanic slag and sand (5 percent), boulder pebble deposits with coarse-grained sand filling (4 percent), and slags and fragments of volcanic rocks and pumice sand (4 percent). Lithologic logs from 832 wells were used to define unit 8 (fig. 8). The western and eastern subregions of the study area had few available lithologic logs. There were more logs available in the southern part of the central subregion (fig. 7). Unit 8 ranked eighth in the total number of wells drilled into the unit (table 8). One potential reason for the lack of lithologic information for unit 8 could be high drilling costs required to complete a well in unit 8 because of large depths (fig. 7). The mean thickness of the unit was $23 \mathrm{~m}$ and the maximum measured thickness, determined from lithologic logs, was $119 \mathrm{~m}$. The maximum interpolated thickness was $106 \mathrm{~m}$ (table 8). The thickest part of the unit, based on the interpolated values, was in the central subregion of the basin (figs. 7, 9).

\section{Hydrogeologic Unit 9}

Underlying unit 8 is a nonwater-bearing unit (confining layer) and the framework's deepest unit, unit 9, which consists primarily of dense basalt andesite dacite, dense clay, and sandy clay with interbedded sand pebbles and gravel. The unit was characterized mostly by dense basalt andesite dacite, which makes up about 46 percent of the geologic unit. Dense clay and sandy clay with interbedded sand pebbles and gravel made up another 53 percent, 43 percent, and 10 percent, respectively. Lithologic logs from 166 wells were used to define unit 9 (fig. 8). Unit 9 had the least number of available wells. However, spatially these wells covered the majority of the study area with the highest concentration of wells located in the basin's center (fig. 7). The mean thickness of the unit was $22 \mathrm{~m}$ thick and the maximum measured thickness, determined from lithologic logs, was $68 \mathrm{~m}$. The unit's maximum interpolated thickness was $92 \mathrm{~m}$ (table 8). The thickest part of the unit, based on the interpolated values, was in the central subregion (figs. 7, 9). 


\section{Groundwater Conditions}

This section describes flowing and nonflowing aquifer conditions, potentiometric surfaces, changes in groundwater levels and well discharge over time, water use, and water quality of the northern Ararat Basin. In the Ararat Basin, the complex geology and hydrologic setting allows for as many as nine hydrogeologic units (fig. 3; table 8), which spatially can vary as the geology changes across the basin. As described previously in the "Hydrogeologic Units" section, four waterbearing units were identified using lithologic descriptions for wells drilled in the northern region of the Ararat Basin (in Armenia) (table 1) and were summarized by Armenian Branch of Mendez England and Associates (2014) in annex 2 of that report. The complexity of these units are, in part, due to the confining units that make up the stratigraphy in the study area. Two primary aquifers were identified by the Armenian Branch of Mendez England and Associates (2014): an unconfined aquifer (equivalent to hydrogeologic unit 2 of this report) and a confined aquifer (equivalent to hydrogeologic units 4, 6, and 8 of this report). The unconfined aquifer (hydrogeologic unit 2) is a shallow aquifer, consisting of a sandy loam and gravel pebble deposits, typically ranging from 0.5 to $60 \mathrm{~m}$ in depth. The general direction of flow in the unconfined aquifer is towards the Aras River (Armenian Branch of Mendez England and Associates, 2014). The deeper confined aquifer identified by Armenian Branch of Mendez England and Associates (2014) and subdivided in this report into water-bearing units 4,6 , and 8 is overlain by a clay layer (unit 1) approximately 1 to $51 \mathrm{~m}$ thick in some areas of the northern part of the basin (table 8; fig. 9), with additional confining clay layers (units 3,5, and 7) between the water-bearing units (table 8). The entire confined aquifer is under artesian conditions and is further characterized in the central parts of the Ararat Basin where the confined aquifer is under flowing artesian conditions, as described in the "Flowing and Nonflowing Aquifer Conditions" section.

\section{Flowing and Nonflowing Aquifer Conditions}

Data obtained during the 2016 well inventory (table 4) were used to generate a map of the nonflowing and flowing wells in the study area (fig. 10). The nonflowing aquifer conditions were on the edges of the Ararat Basin where the basin depth becomes shallower (Armenian Branch of Mendez England and Associates, 2014). The nonflowing wells include wells completed in (1) the unconfined aquifer consisting primarily of sandy loam and gravel pebble deposits (unit 2), and (2) the confined aquifer (units 4, 6, and 8) but with insufficient pressure for the water level to rise above land surface.

The flowing artesian wells were primarily in the central part of the study area (fig. 10). These flowing artesian wells were the primary source of water that sustained the development and growth of the aquaculture industry for the purposes of raising trout, sturgeon, and other cold water fish (Carter and others, 2016). The artesian conditions, generally high water quality, and cool water temperatures enabled aquaculture industries to thrive; however, the flowing wells reduced the artesian pressure in the aquifer. As a result, many wells that were flowing have ceased to flow (Armenian Branch of Mendez England and Associates, 2014; Carter and others, 2016). The changing pressure boundary (defined as the boundary between the flowing and nonflowing wells) is also shown in figure 10. The boundary has migrated south and decreased in area since 1984 as described further in the "Changes in Groundwater Levels and Well Discharge" section.

\section{Potentiometric Surface}

Data collected during the 2016 well inventory were used to construct potentiometric surface maps of the four waterbearing units in the study area. No information on screened interval was available; therefore, it was assumed that the unit coincident with the well's bottom depth contained the well screen. The elevation of the well bottom was compared to the elevations of the tops and bottoms of the four water-bearing hydrogeologic units (units 2, 4, 6, and 8). Then, the well was assigned a unit based on its completion depth. The locations of the 2016 inventory wells and the assigned hydrogeologic unit for each well are shown in figure 11.

Potentiometric surface maps were generated using GIS software for each of the four water-bearing hydrogeologic units (figs. 12-15). The potentiometric surface for hydrogeologic unit 2 (fig. 12) had few available water-level measurements because the focus of the 2016 well inventory was on the confined aquifer and not the unconfined aquifer (Lilith Harutyunyan, ASPIRED program, oral commun., 2017). The direction of groundwater flow in hydrogeologic units 2, 4, 6, and 8 was estimated based on flow paths drawn perpendicular to potentiometric contours.

Hydrogeologic unit 2 is the shallowest aquifer and is considered a surficial aquifer. For hydrogeologic unit 2, the estimated direction of groundwater flow is from the west to north in the western part of the study area (away from the Aras River) and from west to east and north to south (toward the Aras River) in the eastern part of the study area. The flow paths indicate that the Aras River is a losing stream (discharging to groundwater) in the western part of the basin; however, it is gaining (groundwater is discharging to the river) in the eastern part of the basin.

In hydrogeologic unit 4, the general direction of groundwater flow is generally from west to east and north to south (toward the Aras River); however, groundwater flow is northwesterly in the northwestern part of the study area (fig. 13). Hydrogeologic unit 6 has this same general pattern of groundwater flow (fig. 14) as hydrogeologic unit 4. 

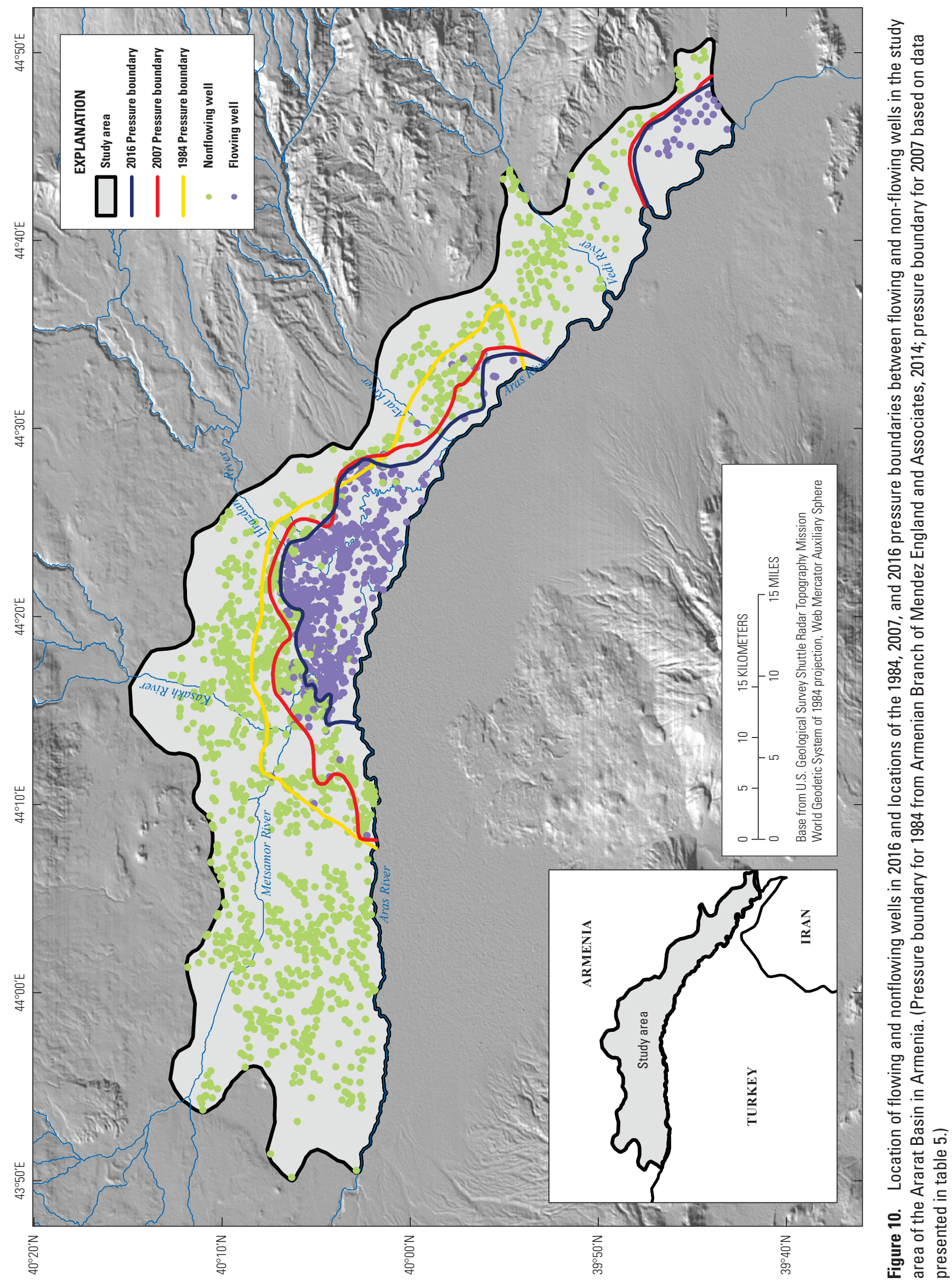


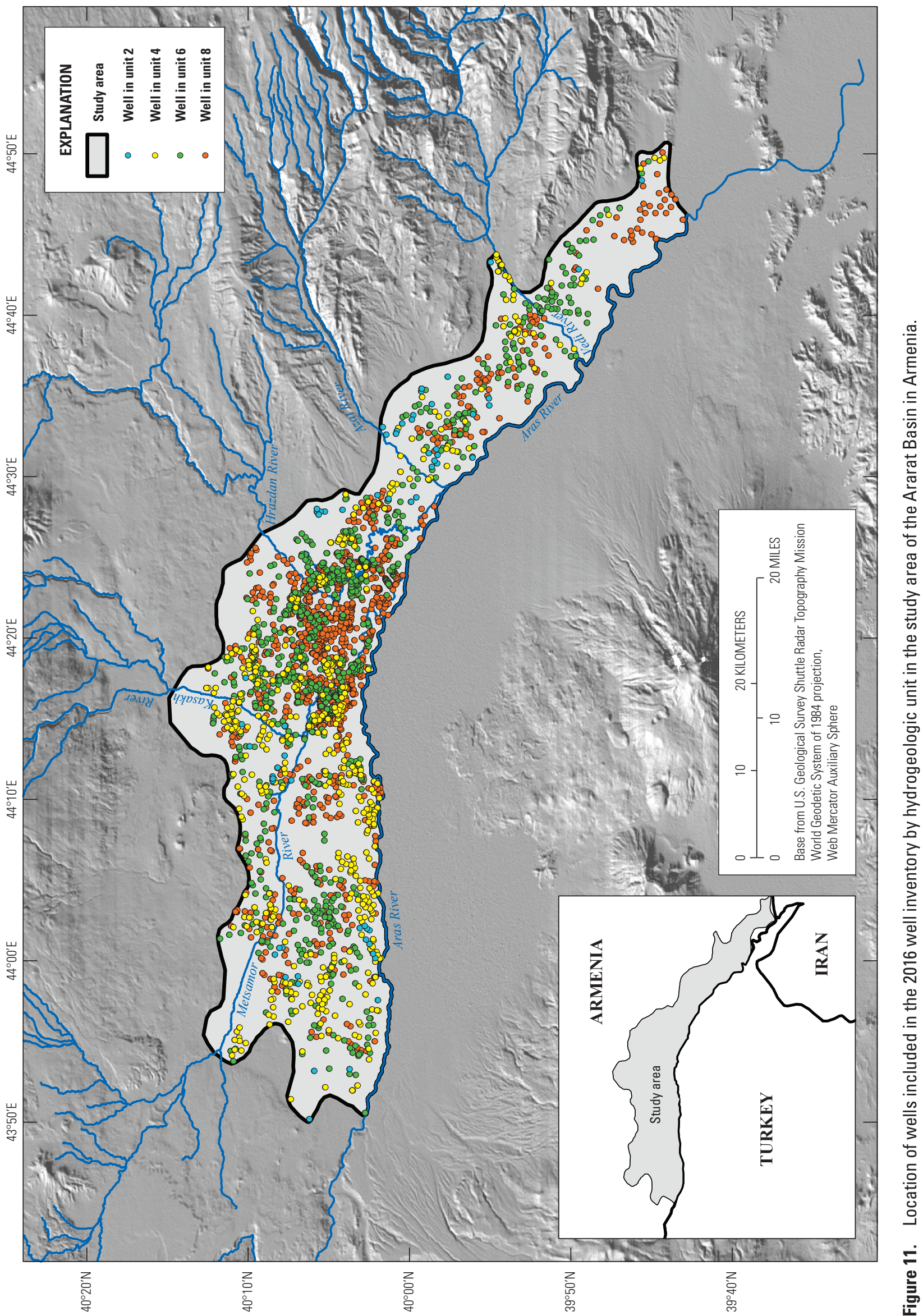




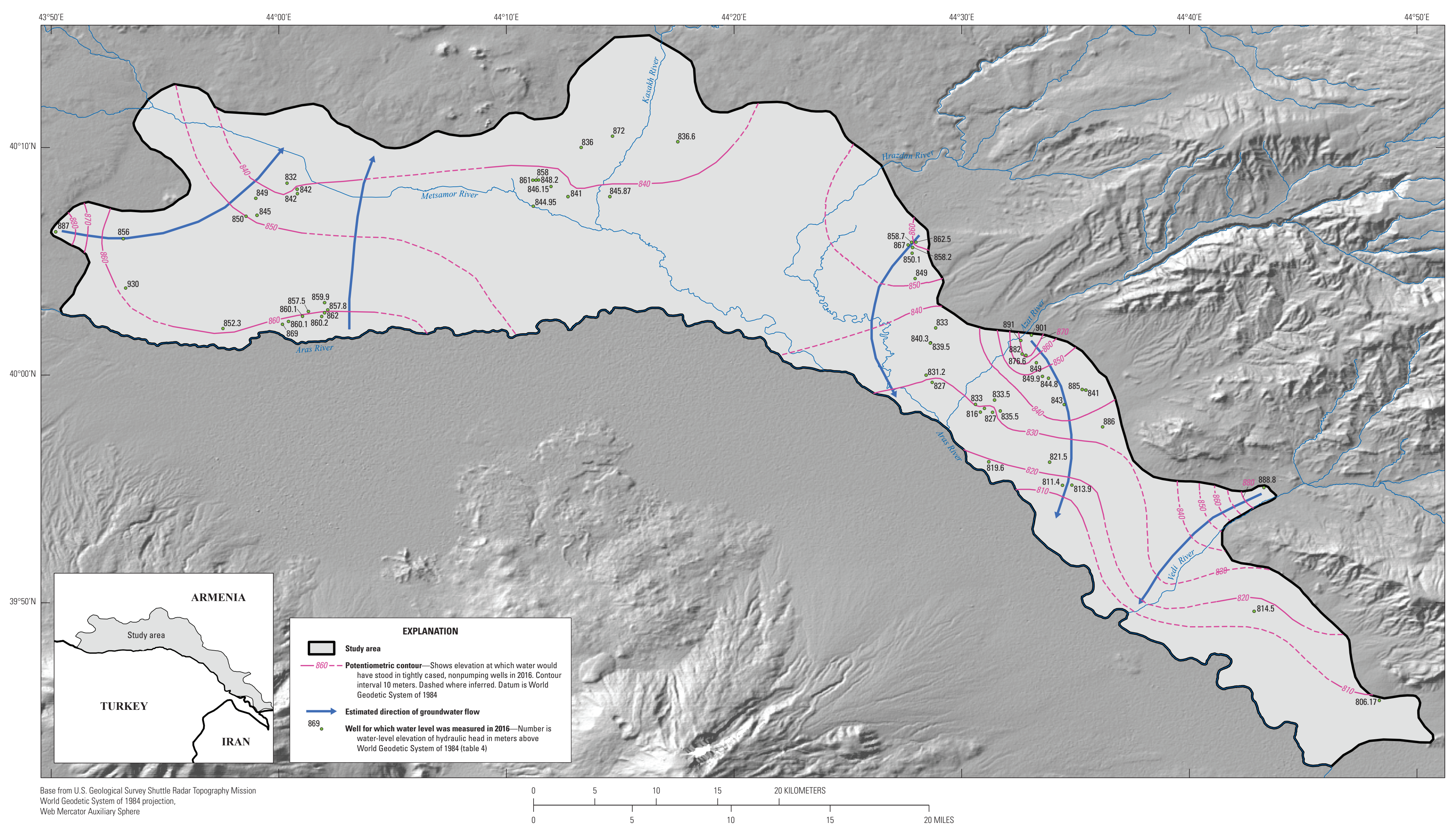

Figure 12. Potentiometric surface of hydrogeologic unit 2 in the study area of the Ararat Basin in Armenia. 


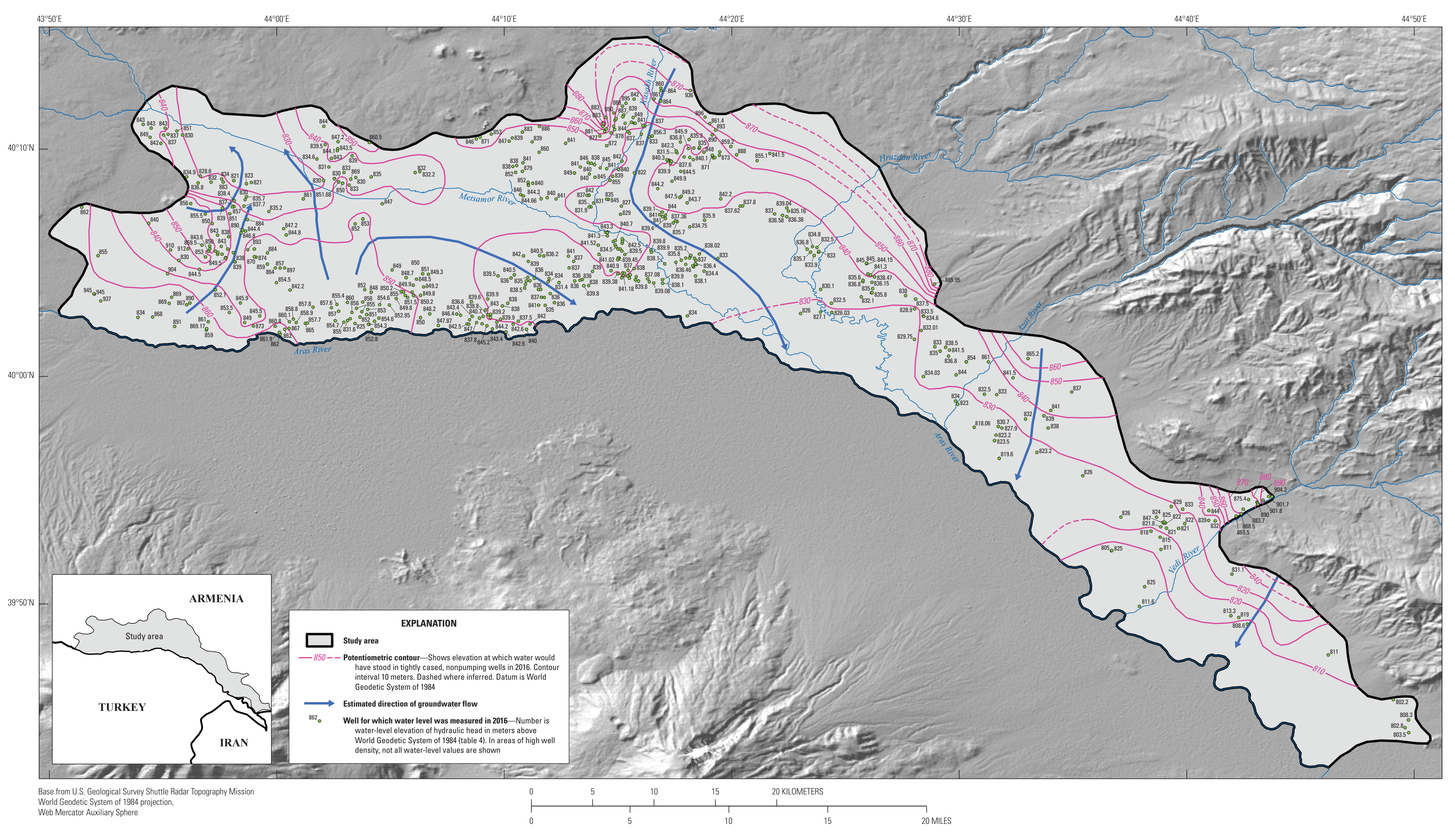

Figure 13. Potentiometric surface of hydrogeologic unit 4 in the study area in the Ararat Basin in Armenia. 


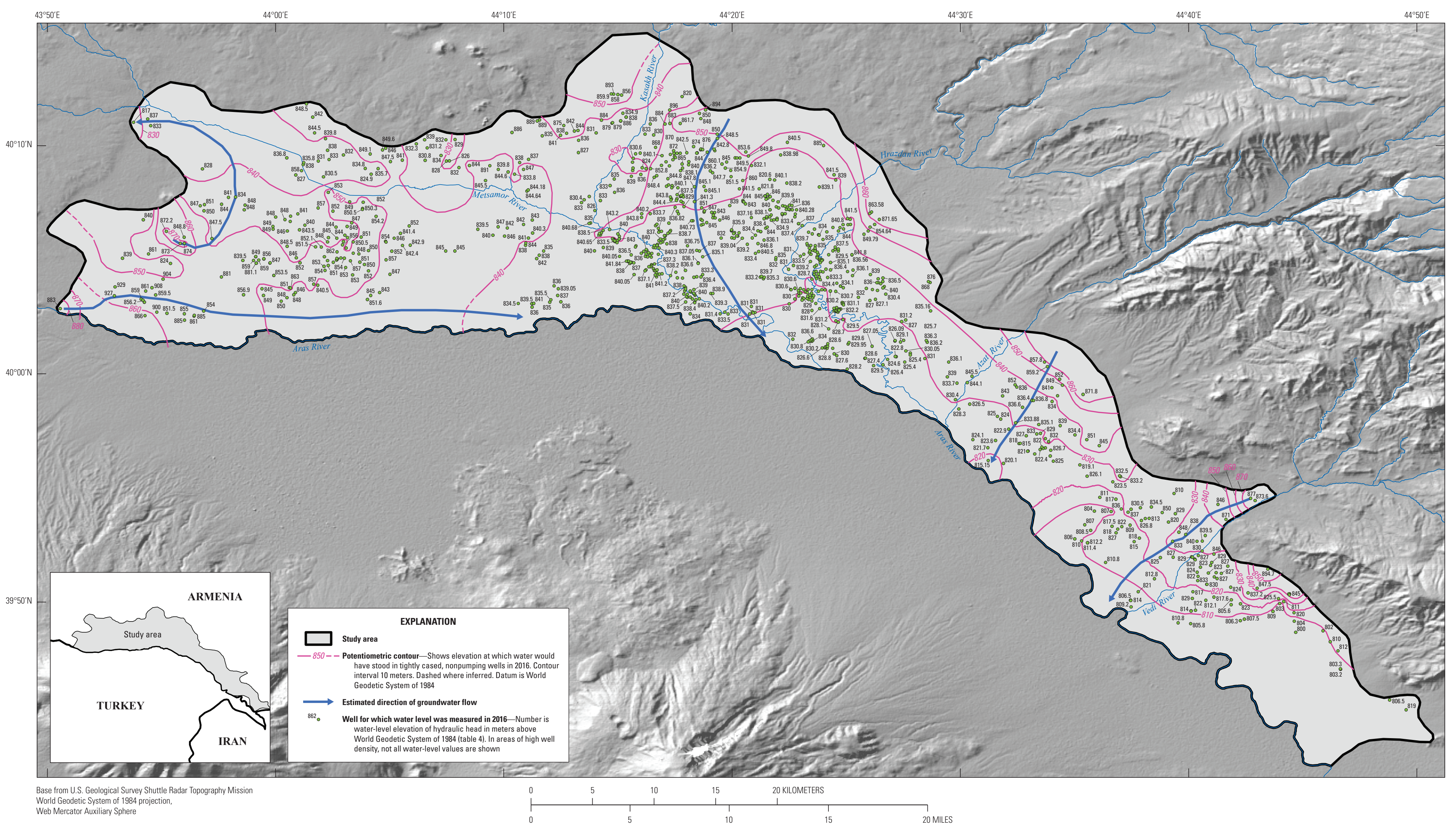

Figure 14. Potentiometric surface of hydrogeologic unit 6 in the study area of the Ararat Basin in Armenia. 


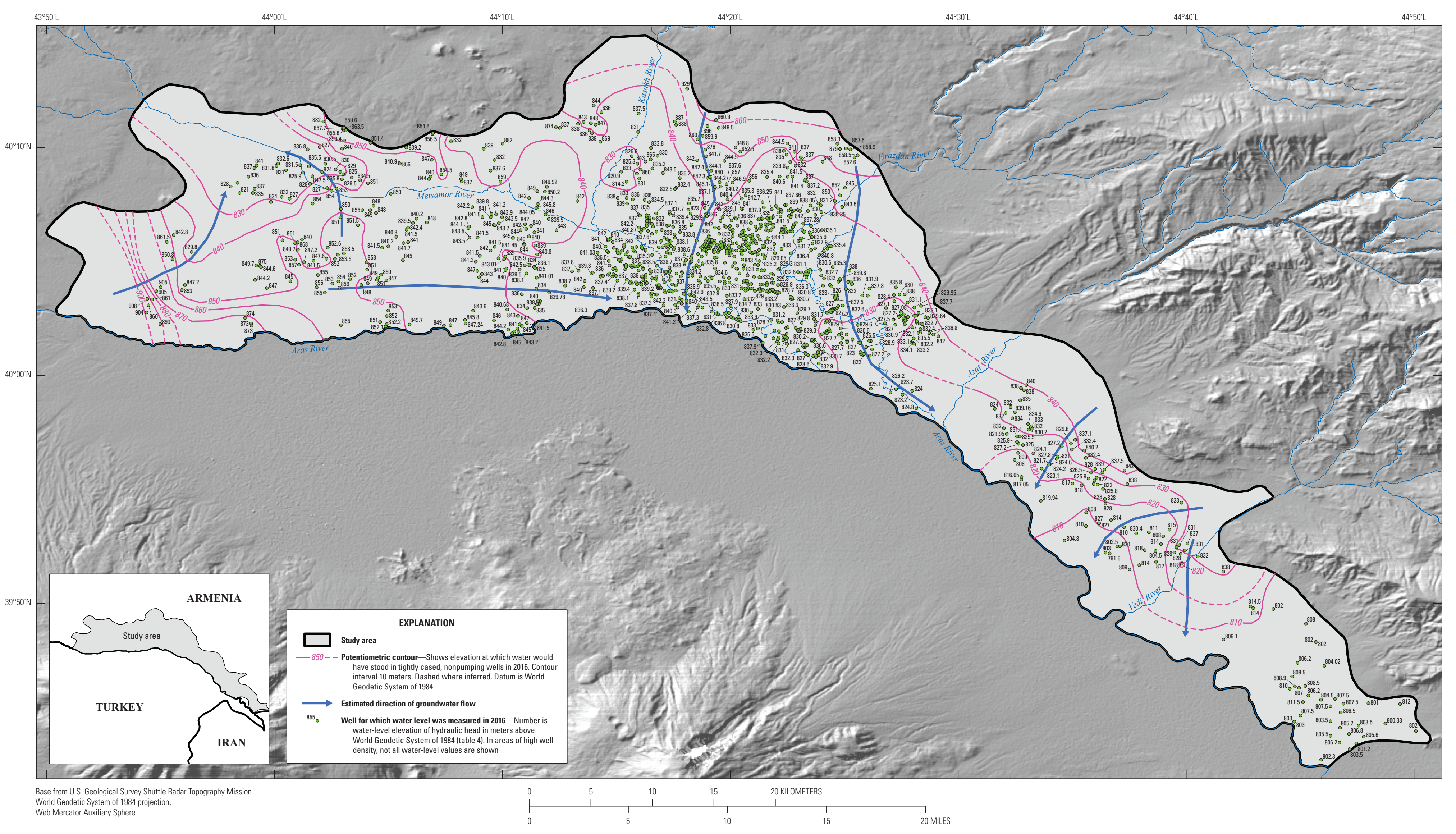

Figure 15. Potentiometric surface of hydrogeologic unit 8 in the study area of the Ararat Basin in Armenia 
Hydrogeologic unit 8 is the deepest of the aquifer units and it is confined in the study area. Groundwater-flow direction is from the south to north (away from the Aras River) in the western part of the study area (fig. 15). Groundwater flow is from west to east and north to south (toward the Aras River) elsewhere in the study area. The large spacing between potentiometric contours in the center of the study area coincides with areas of heavy groundwater withdrawals and high well densities in hydrogeologic unit 8 . The large spacing between potentiometric contours in hydrogeologic unit 8 in the center of the study area could indicate high transmissivity relative to areas with closer contour spacing.

\section{Water Use}

Data collected from 2,807 wells in 2016 (table 4) were used to summarize the water use in the study area (fig. 16). There were 1,012 wells (36 percent) classified as nonoperational, sealed, or temporarily closed. Of the nonoperational wells, 127 wells were free-flowing and designated as abandoned wells. An example of an abandoned flowing well is shown in figure 17. Abandoned wells create environmental hazards (such as pathways for contamination from the land surface to reach the aquifer if well casing deteriorates in nonflowing wells) and continued depletion of the artesian aquifer from flowing wells (Carter and others, 2016).

The locations of the abandoned flowing wells are shown in figure 18. The sum of the water discharge (as provided through the 2016 well inventory [table 4]) from the 127 abandoned wells flowing to waste was $1,090 \mathrm{~L} / \mathrm{s}$, which is an annual volume of about 34 billion liters. Most of the abandoned wells flowing to waste (75 percent) had previously been used for fish farming. The maximum discharge was measured at $41 \mathrm{~L} / \mathrm{s}$ (table 4). Plugging and sealing of the abandoned wells could reduce groundwater depletion and potentially restore aquifer water-level pressure. Wells discharging the highest volumes (table 4) could be plugged first if resources are limited. The abandoned well flowing $41 \mathrm{~L} / \mathrm{s}$ identified during the 2016 well inventory was plugged and sealed in 2017 as a first step by the Armenian government in controlling water flowing to waste, and other wells are planned for plugging and sealing (Lilith Harutyunyan, ASPIRED program, oral commun., 2017).

The water use by well in the study area was grouped into several categories. The categories were based on data from the 2016 well inventory (table 4) that classified 1,795 wells (64 percent) as operational. For simplicity, some categories listed in the 2016 inventory were combined. The categories and percent water use in 2016 are shown in figure 19. The following categories were grouped from the 2016 inventory list of categories: (1) wells with a use of "land watering" were classified as "irrigation;" (2) wells with a use that included "hydrogeological monitoring" were classified by their consumptive use or uses; (3) wells that had more than one use but had the same combination of uses (just listed in a different order) were combined (for example, wells with a use of "drinking-household, irrigation" were combined with wells with a use of "irrigation, drinking-household"); and (4) wells with multiple uses but with fewer than 10 wells in the category were combined into a "multiple use-undifferentiated" category. Additionally, the 127 wells flowing to waste were included in water-use percentages as a consumptive use (fig. 19).

By water-use category (fig. 19), the largest percentage of the wells (42 percent) was used for irrigation purposes. The second largest percentage was aquaculture, primarily as fish farming, which constituted 17 percent of the wells, followed by drinking-household (15 percent), drinking-household plus irrigation (15 percent), and unused (flowing to waste) (7 percent).

When possible, well discharge data were collected during the 2016 well inventory (table 4). Discharge data included wells that were not permanently closed, sealed, or temporarily closed (as indicated by the "Present (2016) status of well" column in table 4). For wells with a pump (coded as "yes" in the "Pump (yes or no) or self-flowing" column; table 4), the well discharge values represent the capacity of the pump and not the actual discharge.

Maps of well discharge rates for flowing wells used for irrigation and for fish farming in 2016 are shown in figures 20 and 21, respectively. The total discharge rates for wells used for irrigation was $2,200 \mathrm{~L} / \mathrm{s}$. In contrast, the total well discharge rates for fish farming were more than 11 times higher at $24,900 \mathrm{~L} / \mathrm{s}$. This difference could indicate that even though fewer wells were used for fish farming than irrigation, the amount of groundwater withdrawals from the confined aquifers likely is much higher for fish farming than irrigation.

\section{Changes in Groundwater Levels and Well Discharge}

The increasing number of flowing artesian wells has reduced the aquifer's head pressure. As a result, many flowing wells have stopped flowing (Armenian Branch of Mendez England and Associates, 2014; Carter and others, 2016). Additionally, the reduced aquifer pressure caused decreased well discharge rates. For 23 wells listed in table 6, discharge rates (well yields) decreased by an average of $94 \mathrm{~L} / \mathrm{s}$ from 1981 to 2013. In the same 23 wells, water levels decreased between about $2 \mathrm{~m}$ and $15 \mathrm{~m}$ between 1981 and 2013, with a mean water-level decrease of about $9 \mathrm{~m}$.

As shown in figure 10, the pressure boundary (boundary between flowing and nonflowing wells) shrank between 1984 and 2016, indicating that a large area has been affected by groundwater depletion. A spatial analysis was performed using GIS software for the pressure boundaries for 1984 and 2016 (fig. 10). The area within the study area with flowing wells (within the pressure boundary) was approximately $619 \mathrm{~km}^{2}$ in 1984 but decreased to $291 \mathrm{~km}^{2}$ in 2016. This is more than a 50-percent reduction in area between 1984 and 2016. 

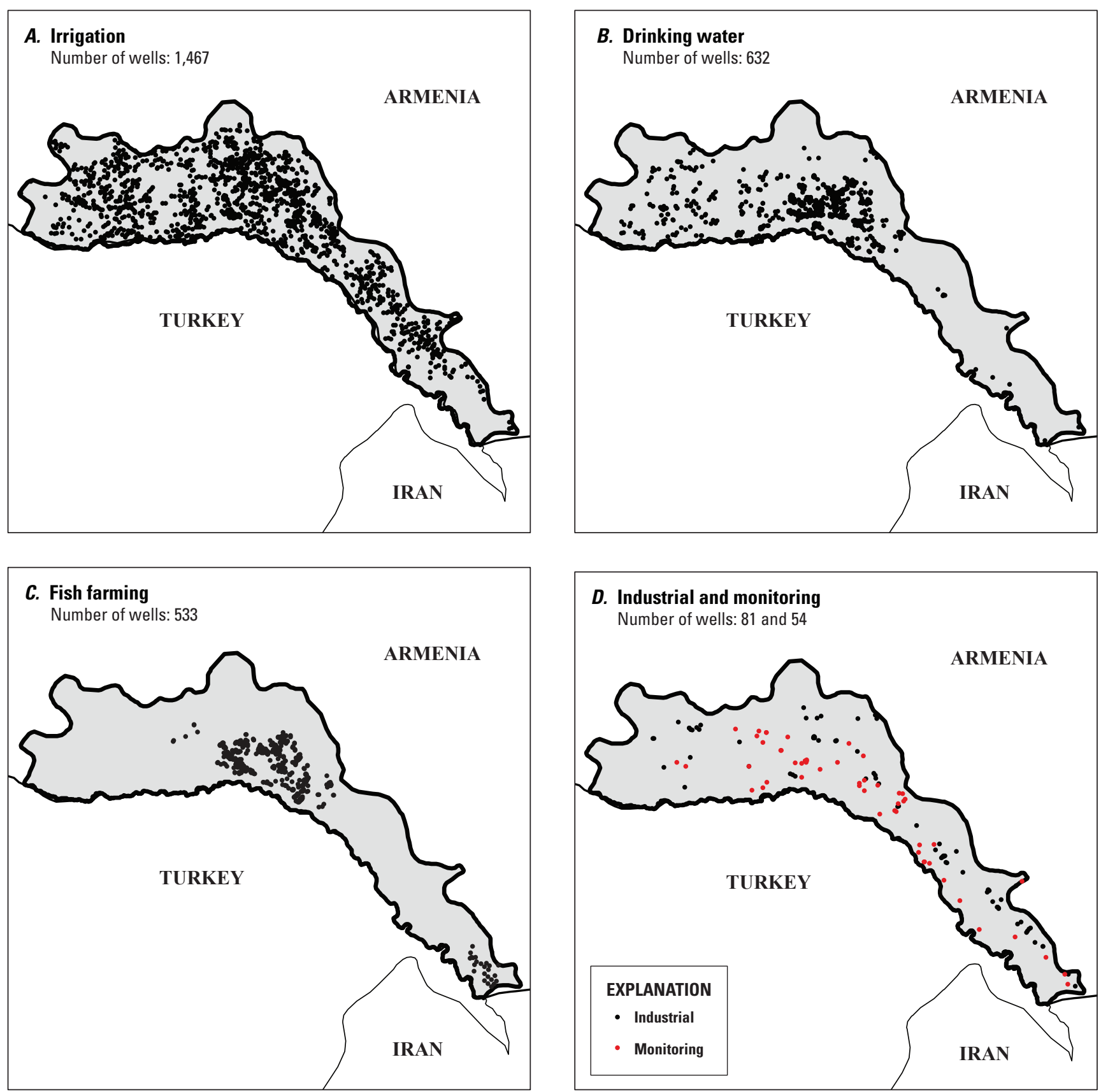

Base from U.S. Geological Survey

World Geodetic System of 1984 projection,

Web Mercator Auxiliary Sphere

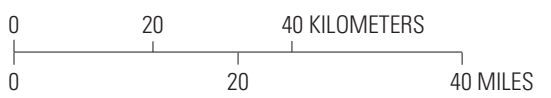

Figure 16. Spatial distribution of wells with various water uses in 2016 in the study area of the Ararat Basin in Armenia. 
The shrinking area of flowing conditions has affected urban and rural communities. The flowing artesian wells supplying drinking water and irrigation water to 31 communities have ceased flowing. The Armenian Nuclear Power Plant at Metsamor is no longer able to meet its water requirements from spring discharges (Yu and others, 2014). The locations of previous and current drinking water wells are shown in figure 22. It is likely that the wells that are no longer used for drinking water were abandoned because they ceased flowing.

The water-level data collected in 2007 (table 5) and 2016 (table 4) were used to generate a raster grid of the hydraulic heads in both years using GIS software (using inverse-distance weighting based on the nearest 12 neighbors; Esri, 2017); these years were selected because of the availability of many water levels in those years. The 2016 raster grid was then subtracted from the 2007 raster grid to determine the change in hydraulic head between 2007 and 2016 (fig. 23). The largest decreases (more than $2 \mathrm{~m}$ ) in hydraulic head between 2007 and 2016 fell outside the 2016 pressure boundary. Within the pressure boundary, changes in hydraulic head generally were minimal or indicated slight increases. It should be noted that the areas where increases were indicated are areas with little overlapping water-level data between 2007 and 2016 (there were many more wells in 2016 than in 2007), which likely affected the accuracy of the analysis.

\section{Water Quality}

For the 2016 well inventory (table 4), specific conductance and water temperature were field-measured by Armenian partners using methods described in the "Water-Quality Data" section. Specific conductance measures the ability of water to conduct electrical current (Hem, 1985). Specific conductance can be used to determine the approximate concentration of dissolved solids in water. Water from 540 wells was measured for specific conductance (table 4; fig. 24). The minimum specific conductance value was 377 microsiemens per centimeter $(\mu \mathrm{S} / \mathrm{cm})$, the maximum value was $4,000 \mu \mathrm{S} / \mathrm{cm}$, and the mean was $998 \mu \mathrm{S} / \mathrm{cm}$. For 59 percent of the wells, specific conductance ranged from 500 and $1,000 \mu \mathrm{S} / \mathrm{cm}$. For 32 percent of the wells, values were between 1,000 and 2,000 $\mu \mathrm{S} / \mathrm{cm}$ (fig. 25). Less than 4 percent of the wells had specific conductance values less than $500 \mu \mathrm{S} / \mathrm{cm}$, less than 5 percent had values between 2,000 and $3,000 \mu \mathrm{S} / \mathrm{cm}$, and less than 1 percent of the wells had values greater than $3,000 \mu \mathrm{S} / \mathrm{cm}$.

Water temperature was field-measured for 2,470 wells (table 4). The maximum water temperature was 24.2 degrees Celsius. A visual analysis between water temperature and well depth indicated no relation. The spatial distribution of water temperature is shown in figure 26. Most wells with cooler water temperatures are within the 2016 pressure boundary or in the western part of the basin. Wells with generally warmer water temperatures are in the eastern part of the basin. The typical temperature of groundwater from the artesian aquifer is 13 degrees Celsius (Meyer, 2015).

The stable isotopes of hydrogen (denoted as $\delta \mathrm{D}$ ) and oxygen (as $\delta^{18} \mathrm{O}$ ) of the water molecule can be used to help differentiate groundwater flow paths and probable recharge sources. Water samples for isotope analysis were collected in March 2016 to determine potential sources of recharge to the Ararat Basin artesian aquifers. Five sites were sampled: four groundwater and one surface water (table 7; fig. 1). Additional sampling at more sites is needed for better evaluation and possible differentiation of recharge sources.

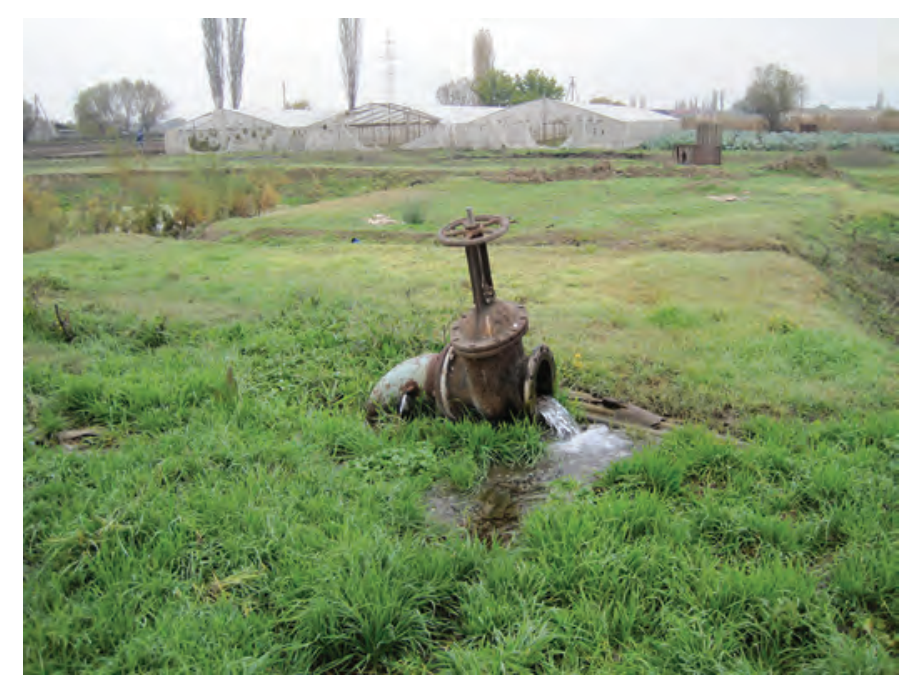

Figure 17. An abandoned well flowing water to the land surface in November 2015 in the Ararat Basin in Armenia. 


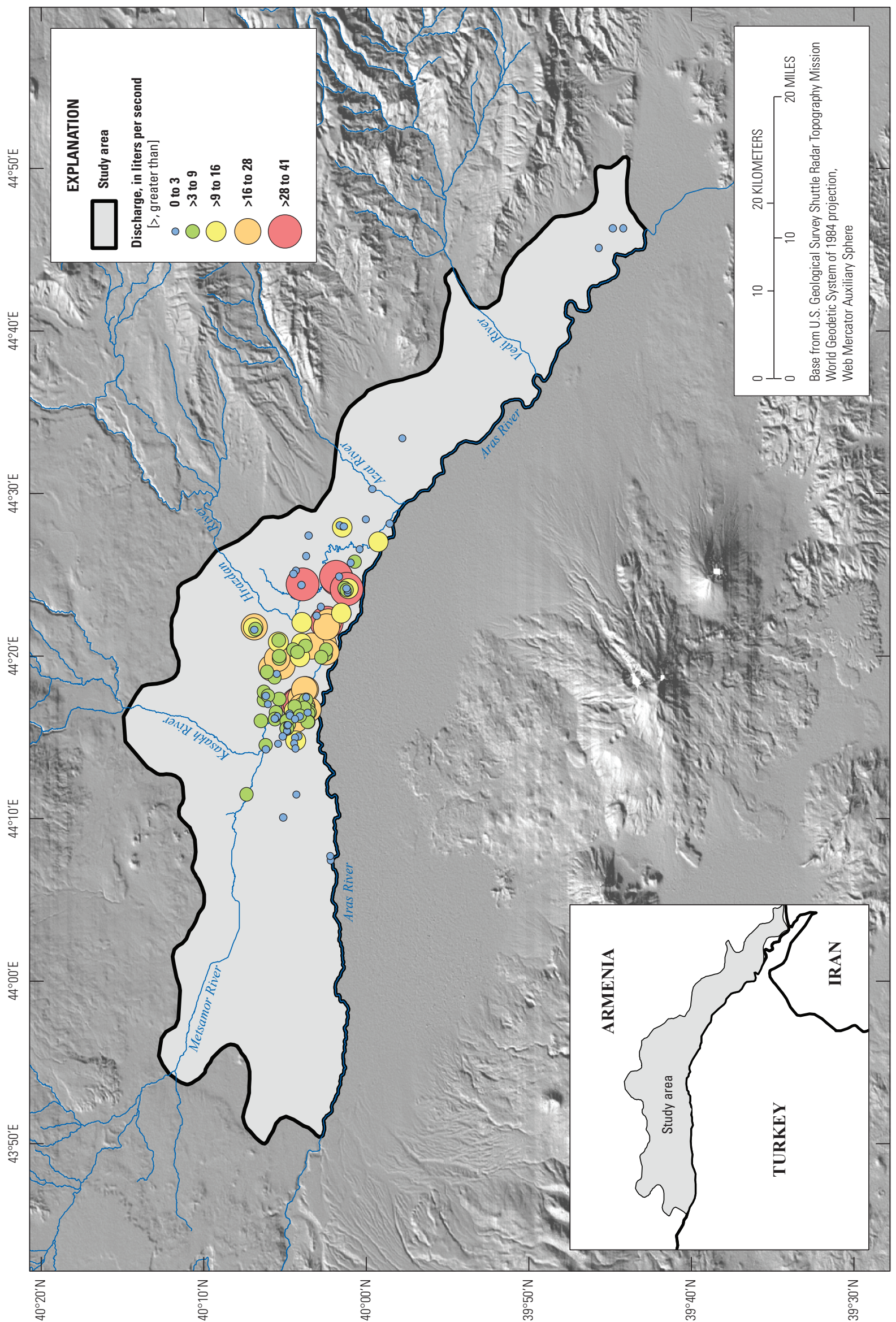

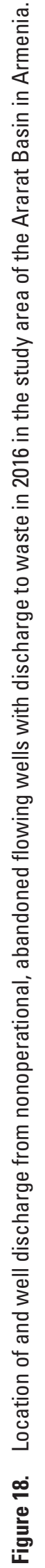




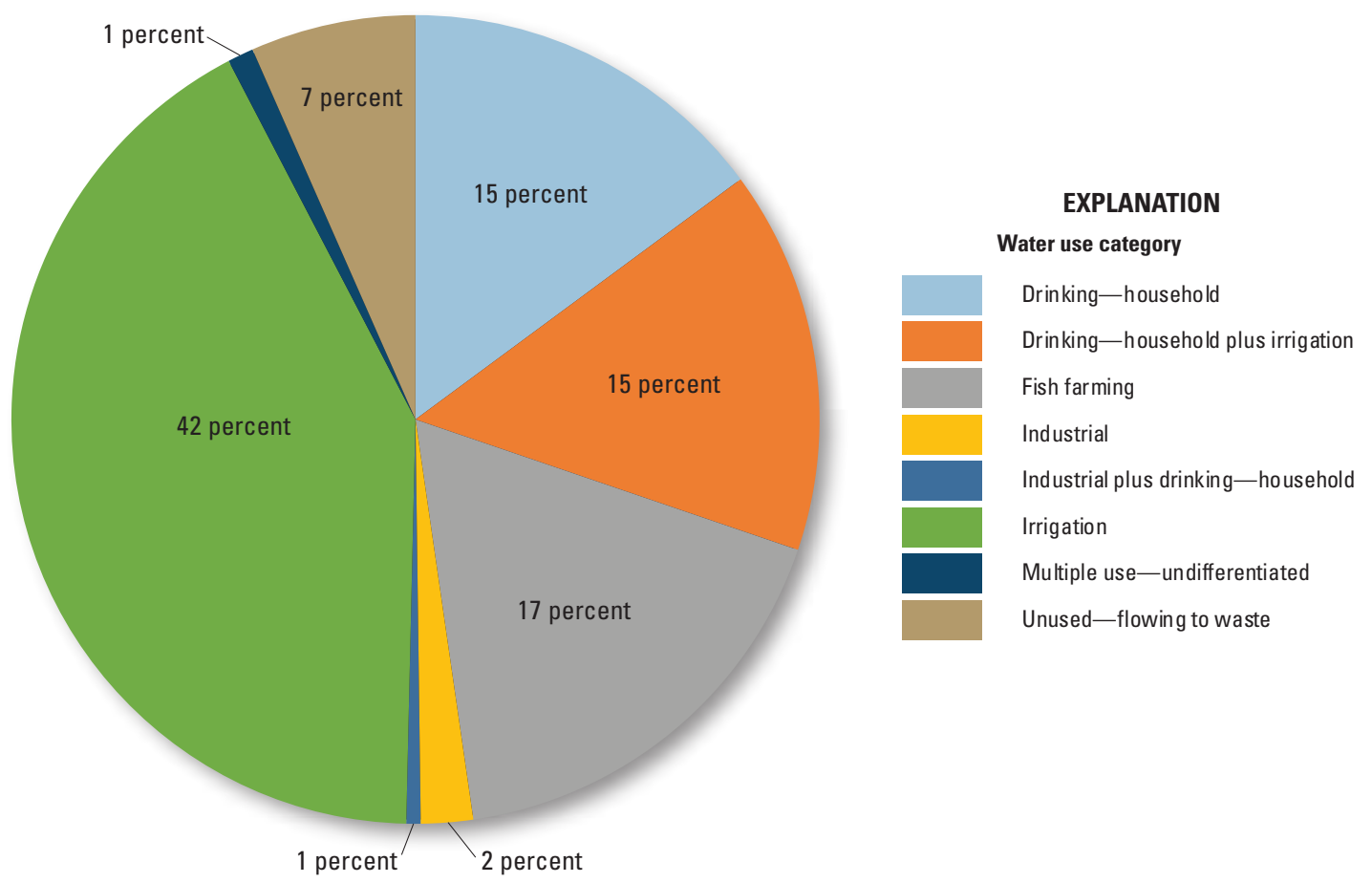

Figure 19. Percentage of wells by use of water based on wells inventoried in 2016 in the study area of the Ararat Basin in Armenia.

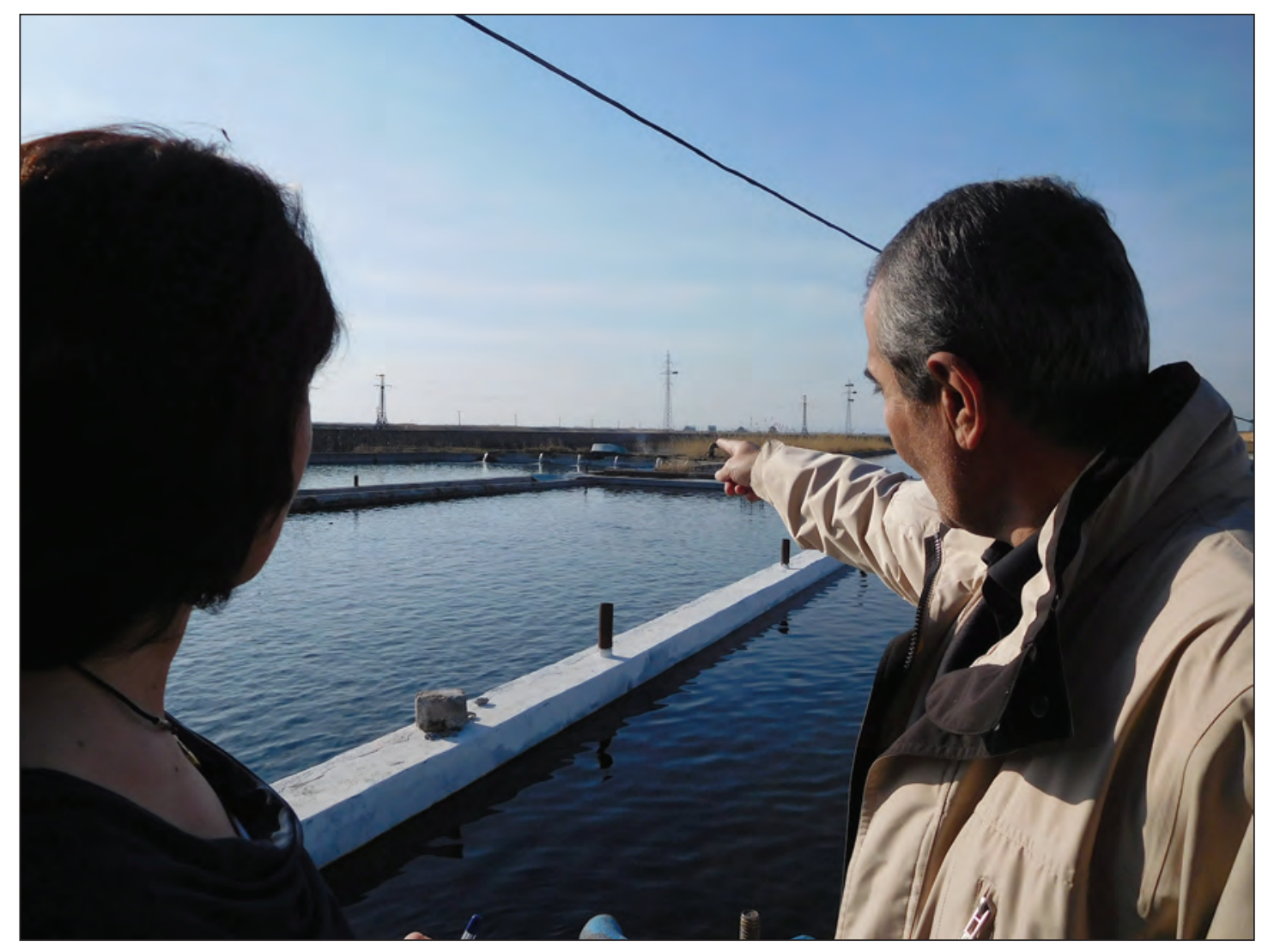

Fish farm that raises sturgeon, trout, and other cold-water fish using groundwater withdrawals from an artesian aquifer in the Ararat Basin. 


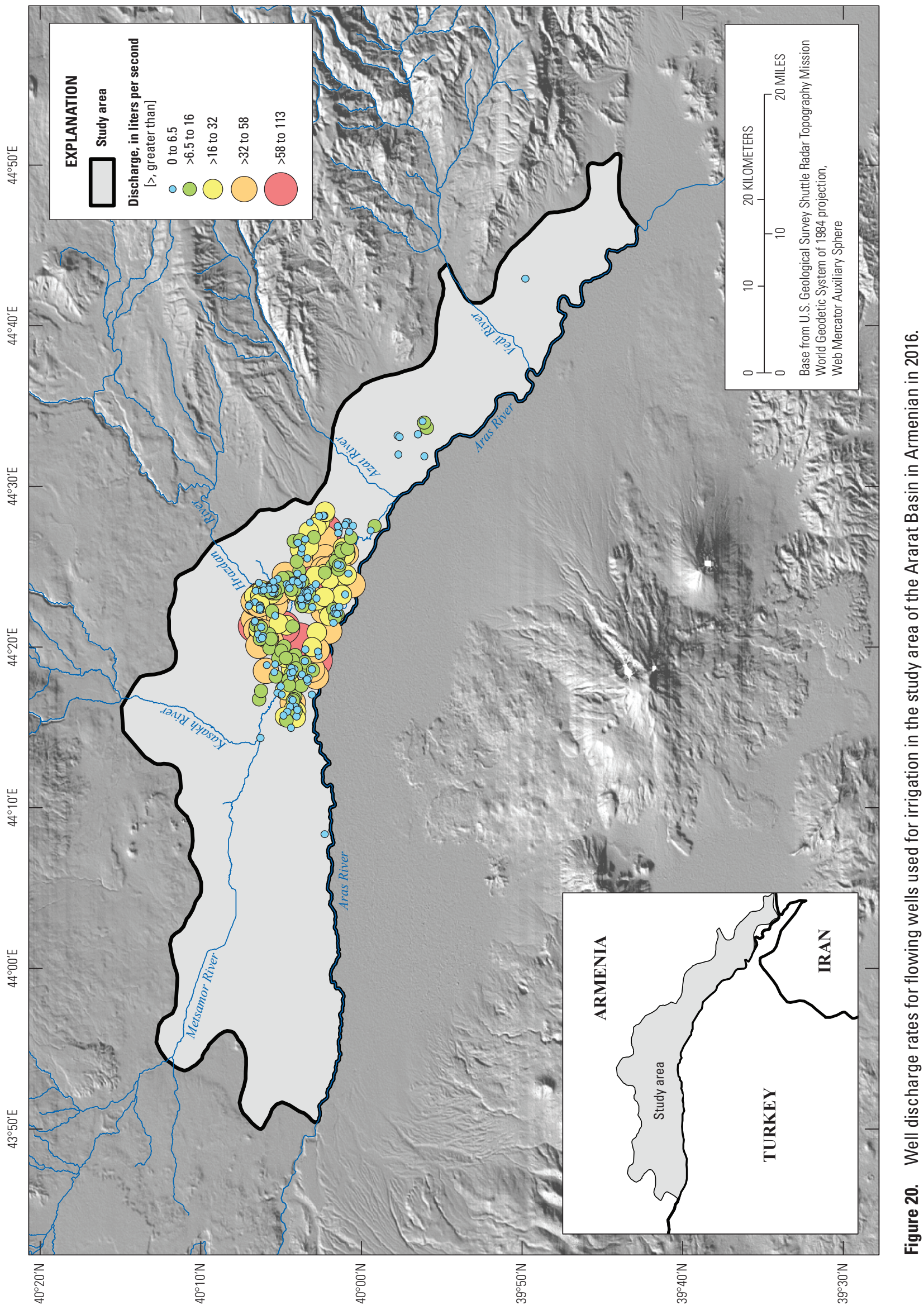




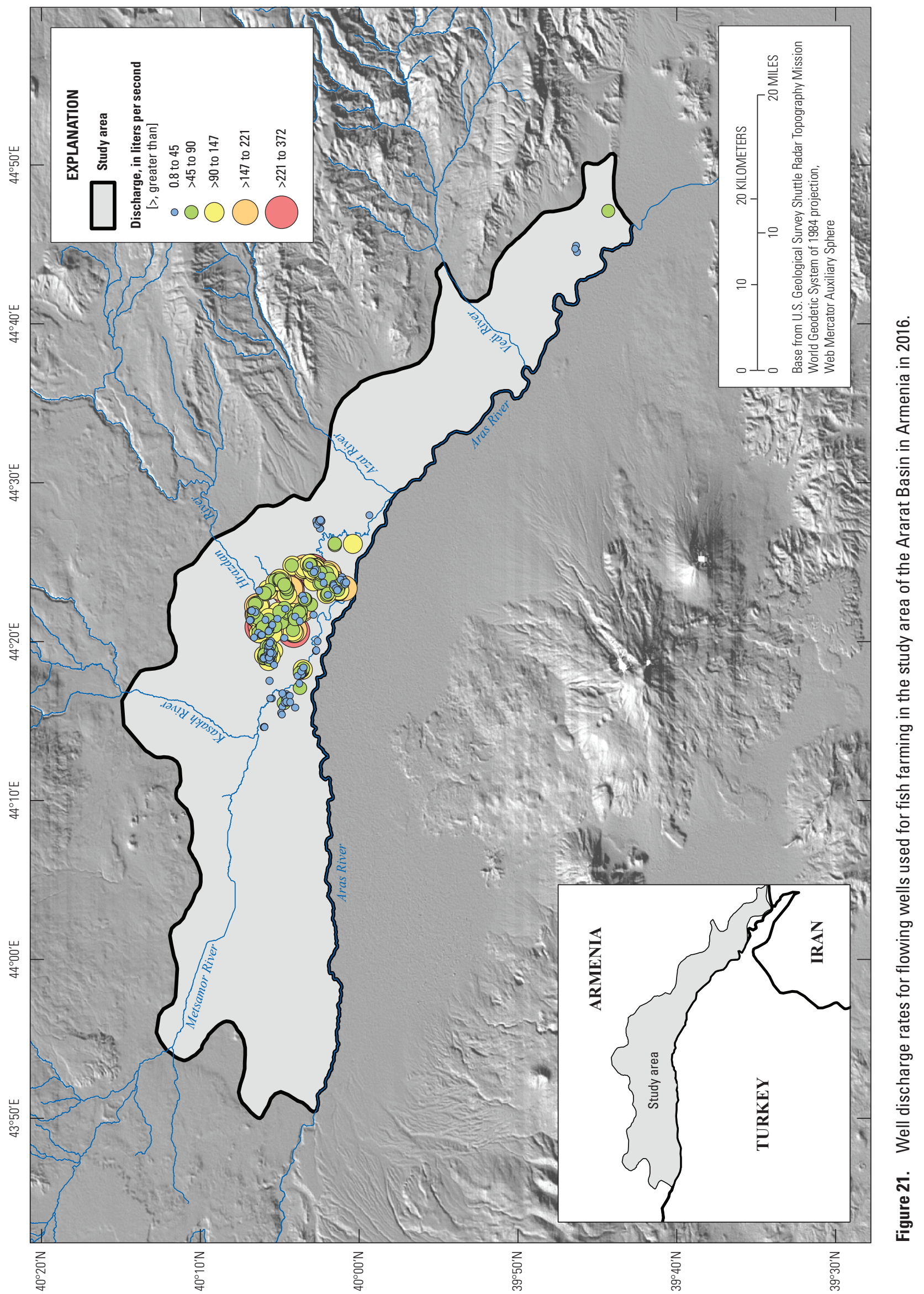




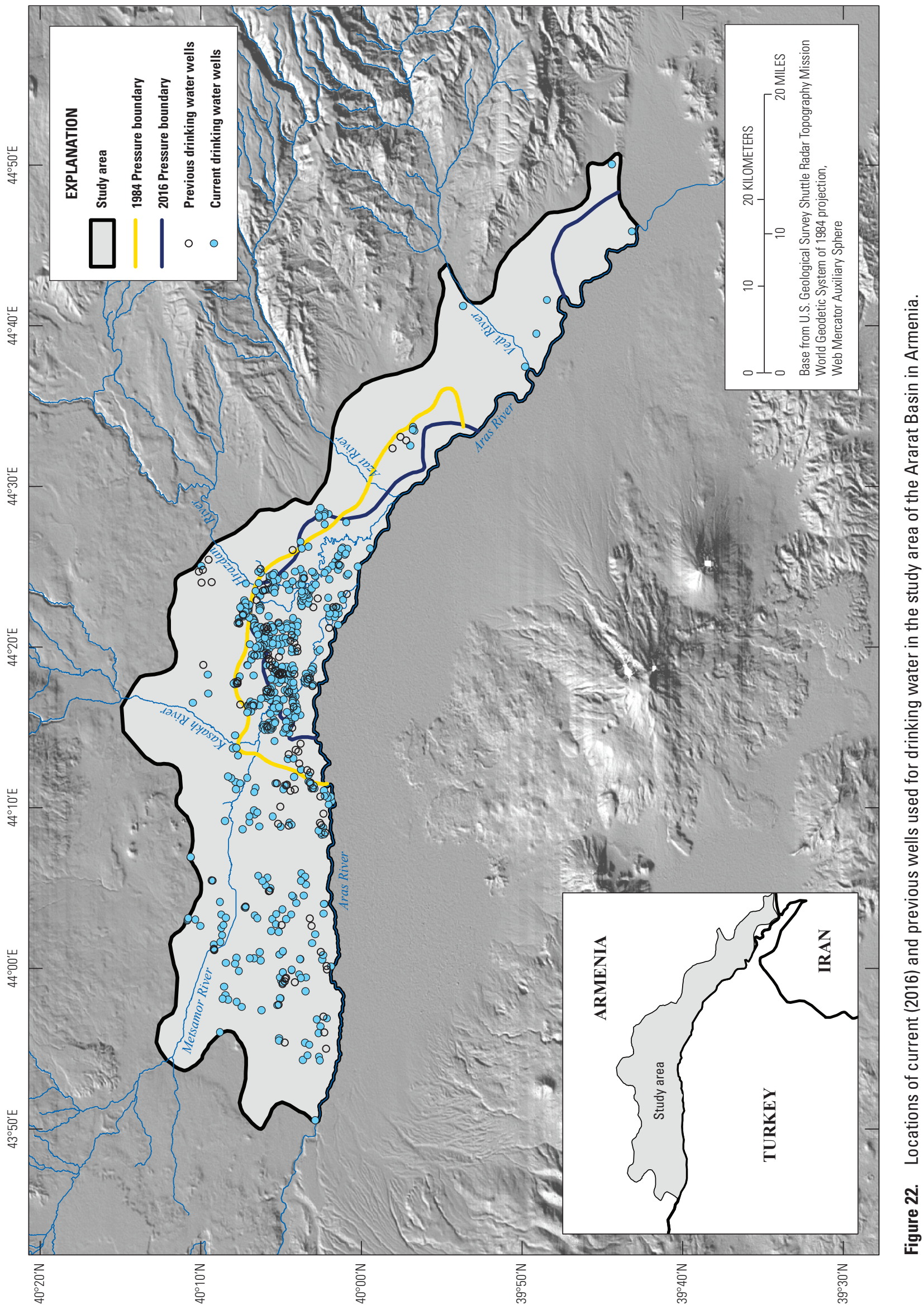




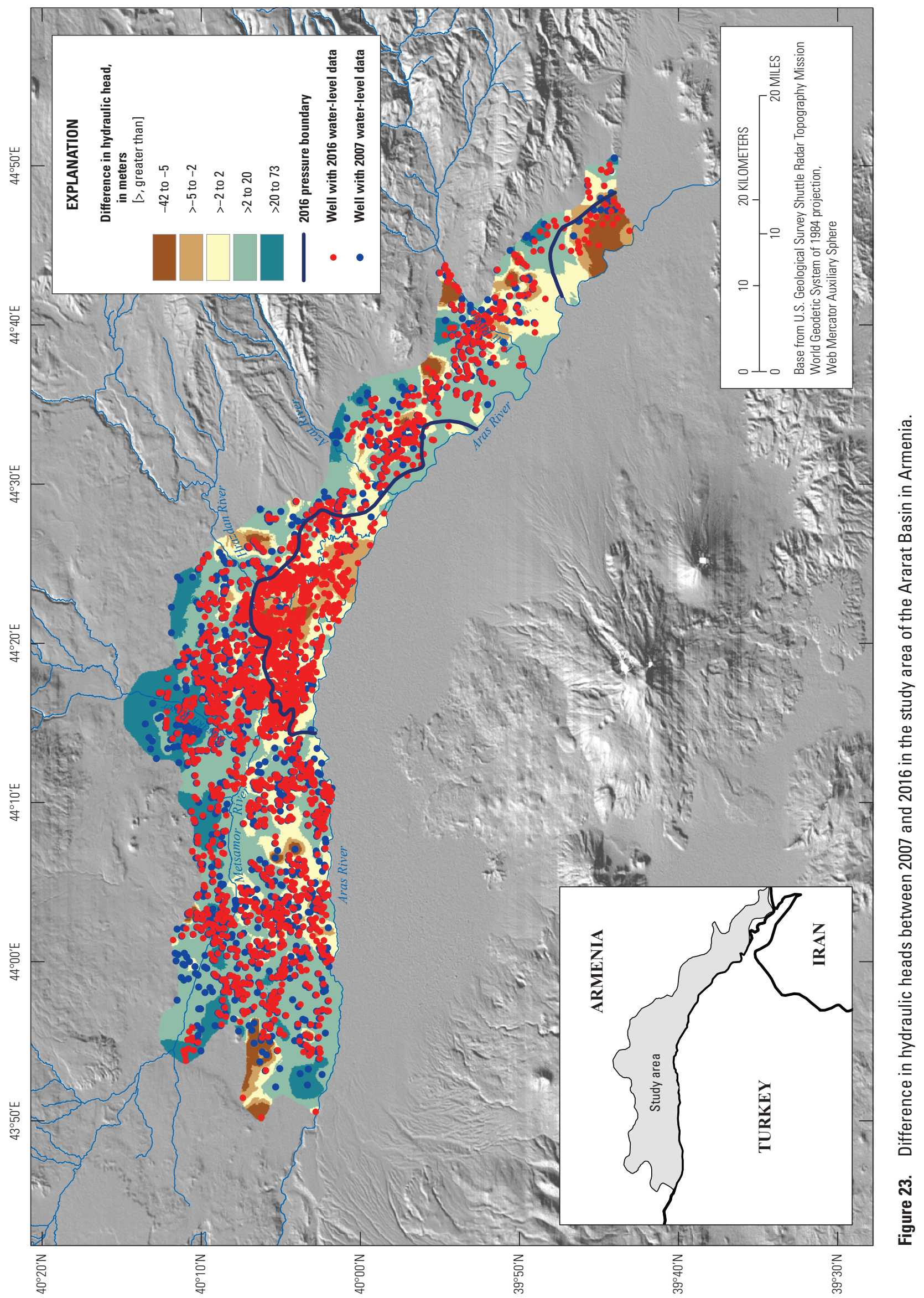




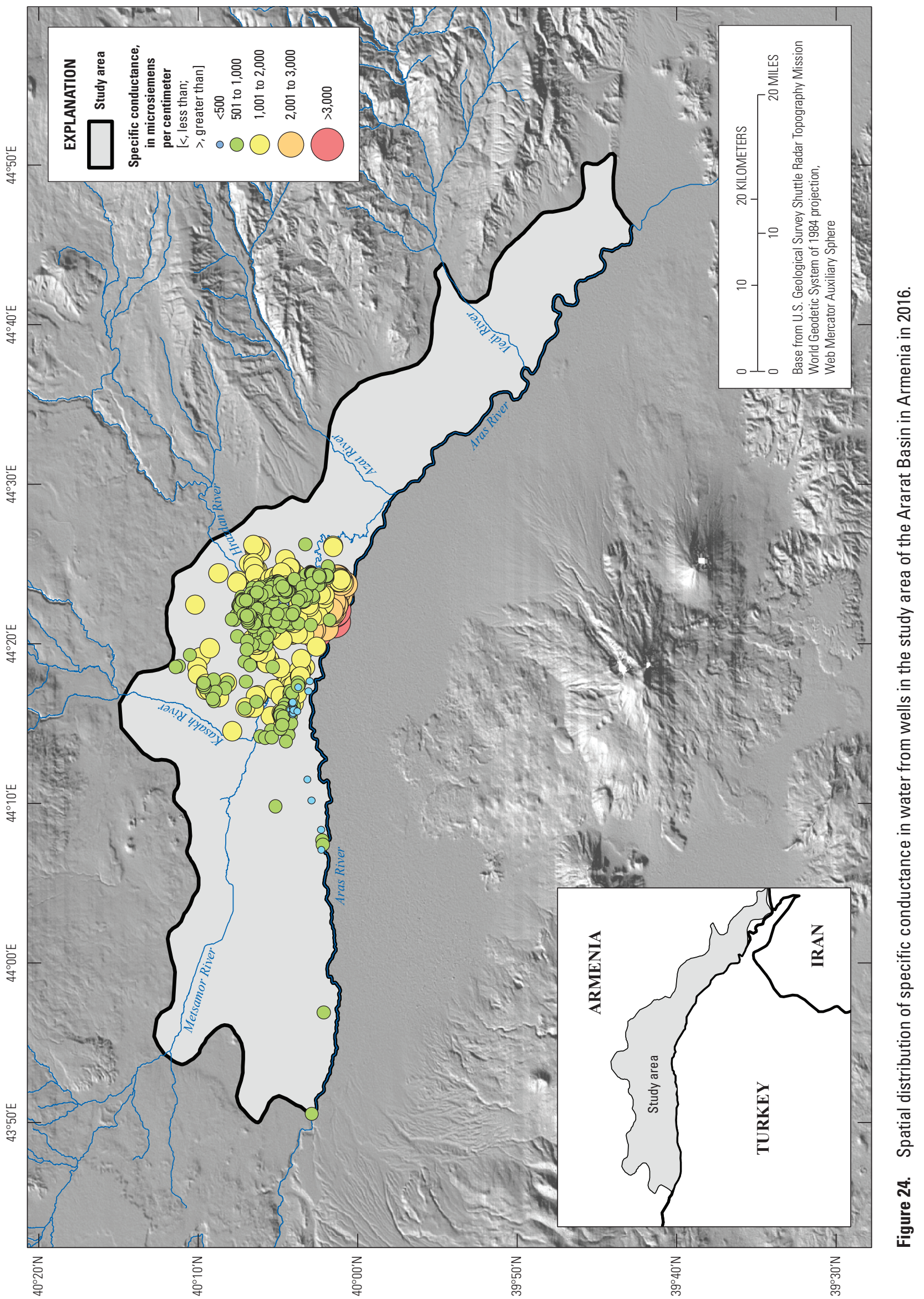




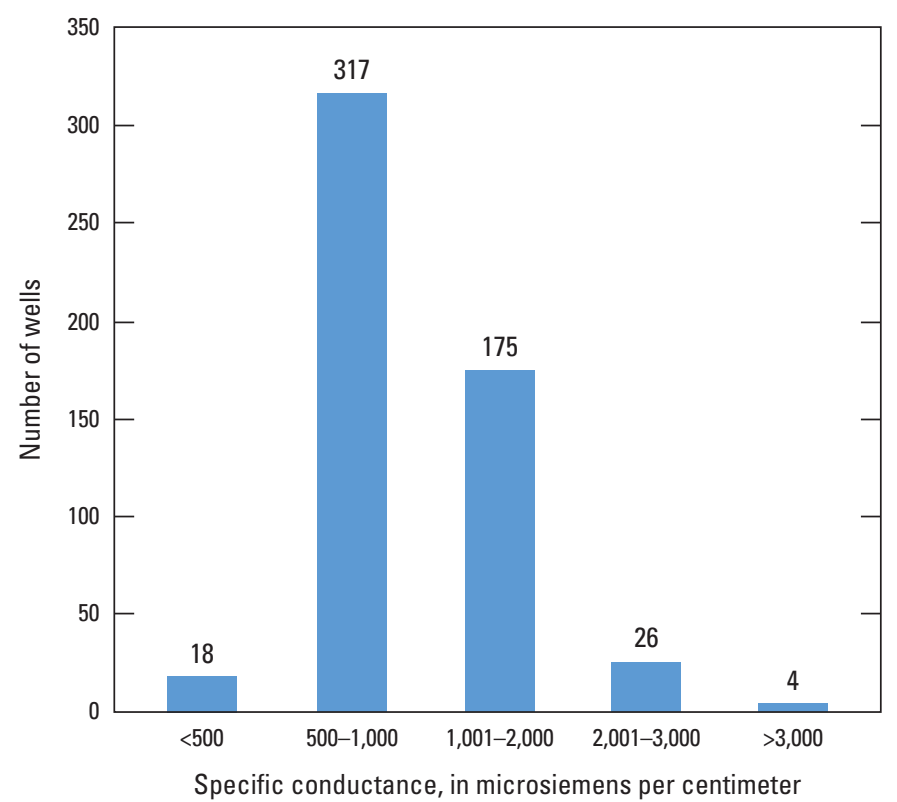

Figure 25. Distribution of ranges of specific conductance values in the study area of the Ararat Basin in Armenia in 2016.

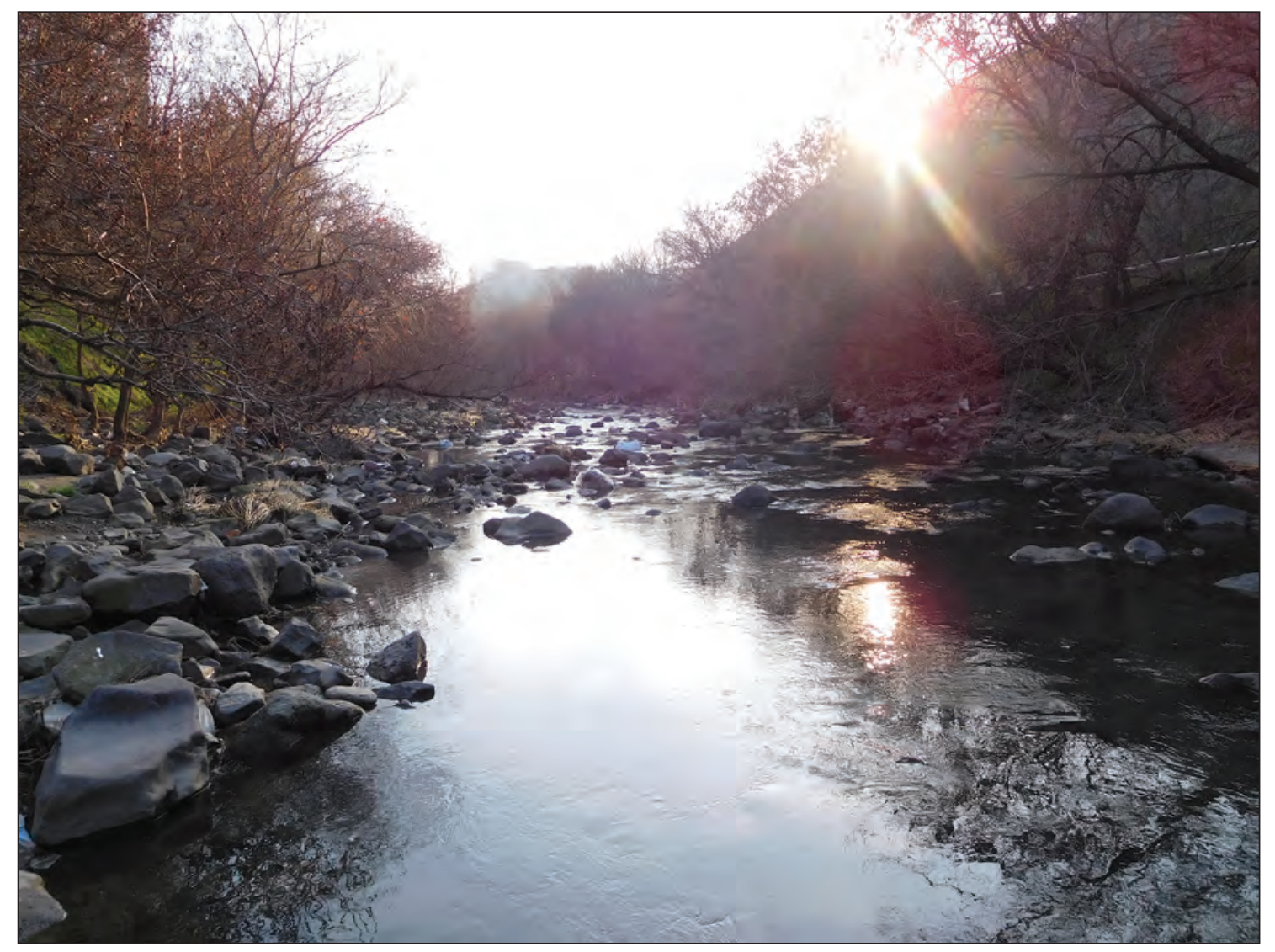

Hrazdan River at Yerevan, Armenia, where water samples were collected for analysis of select stable isotopes. 


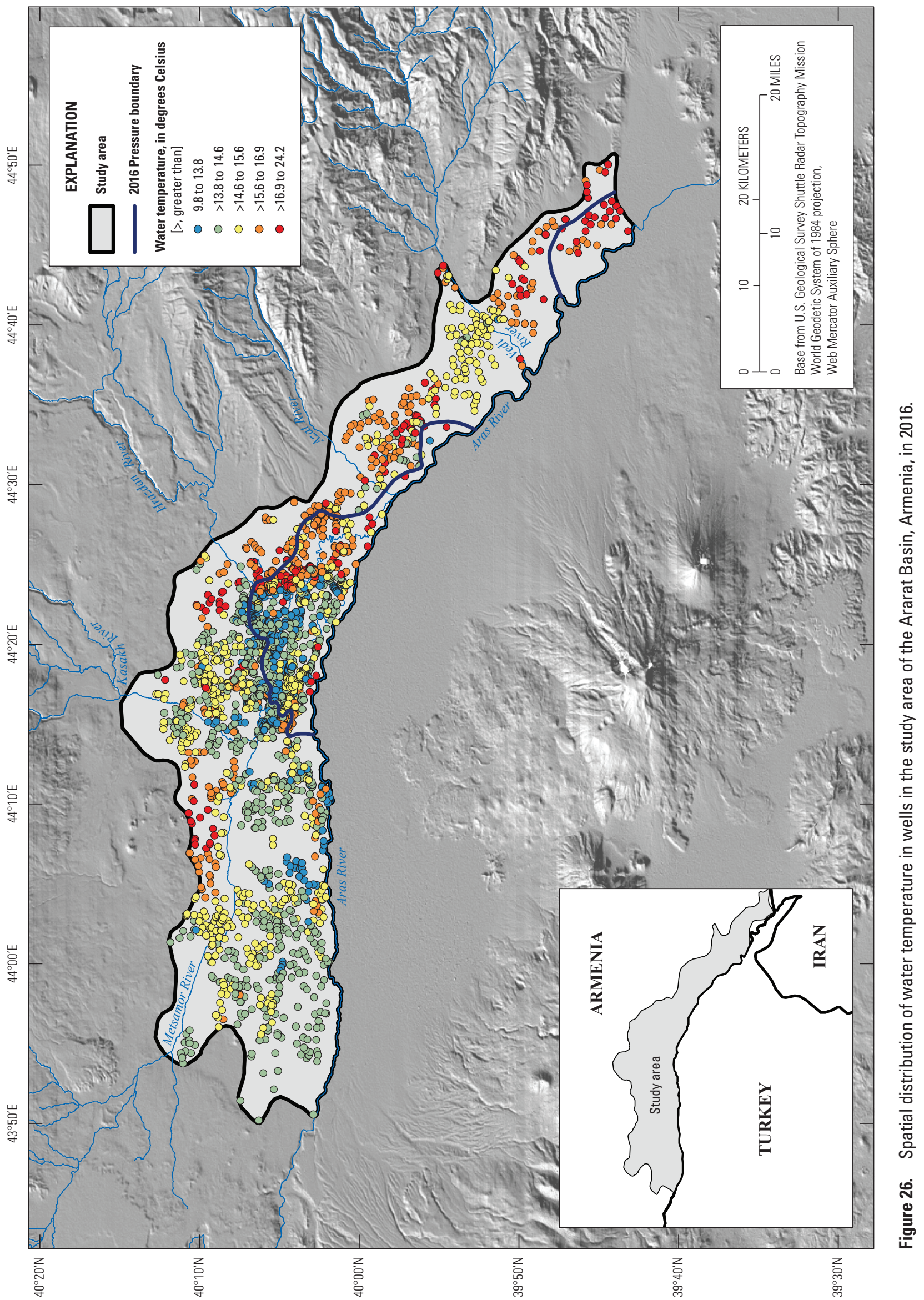


The isotope sample results were plotted with the Global Meteoric Water Line in figure 27 (Craig, 1961). The Ararat Basin water samples fell above the Global Meteoric Water Line, indicating the sampled waters have origins from a slightly more humid source than the global average. The waters (four groundwater and one surface-water site) had similar stable-isotope values, indicating similar recharge sources for the sampled wells. The Hrazdan River sample (fig. 1) was consistent with the groundwater samples, indicating the river could serve as a source of recharge to the Ararat artesian aquifer.

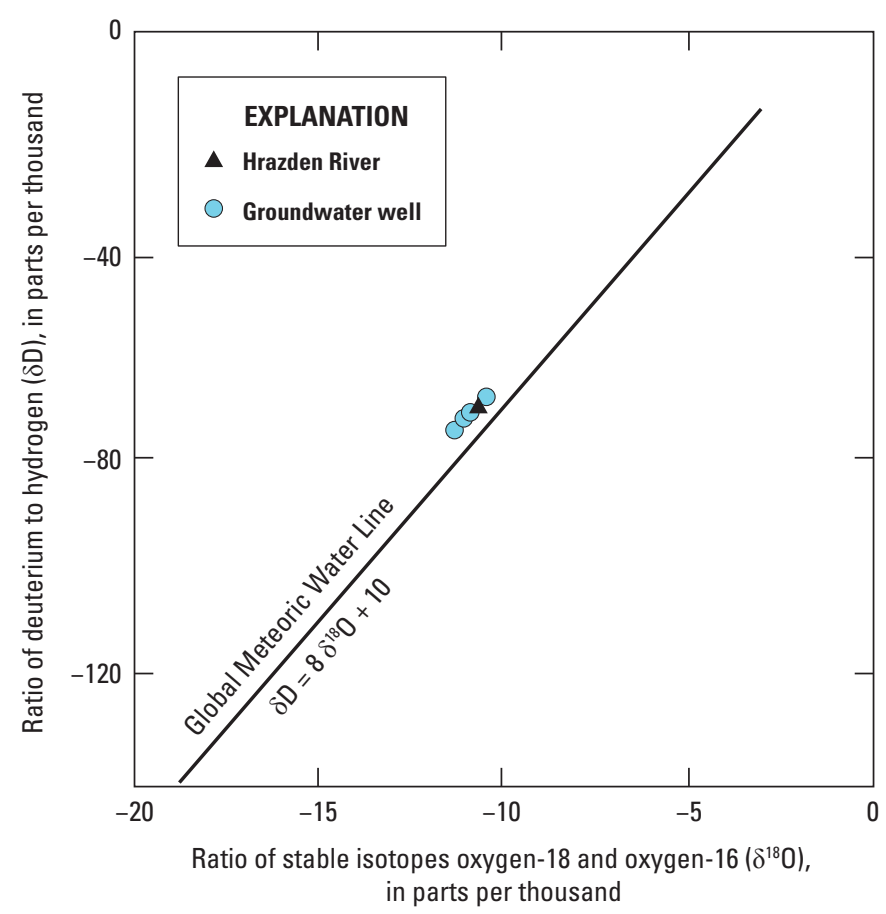

Figure 27. Isotopic composition of water samples from wells and Hrazdan River in the study area of the Ararat Basin compared to Global Meteoric Water Line (Craig, 1961).

\section{Summary}

Armenia is a landlocked country located in the mountainous Caucasus region between Asia and Europe. Armenia shares borders with the countries of Georgia on the north, Azerbaijan on the east, Iran on the south, and Turkey and Azerbaijan on the west. Groundwater supplies 96 percent of the water used for drinking water purposes and about 40 percent of all water withdrawn in the country is from groundwater. Since 2000, aquaculture demands and other uses have increased groundwater withdrawals in the Ararat Basin (Ararat Valley) in Armenia. The Ararat Basin is a transboundary basin located in both Armenia and Turkey. The basin is bisected from west to east by the Aras River. Increased groundwater withdrawals in Armenia resulted in decreased springflows, reduced well discharges, lower well water levels, and a reduction of the number of flowing artesian wells in the Ararat Basin.

In 2016, the U.S. Geological Survey (USGS) and the U.S. Agency for International Development (USAID) began a cooperative study in Armenia to share science and field techniques to increase the country's capabilities for groundwater study and modeling. This study is in partnership with USAID/ Armenia in the implementation of its Science, Technology, Innovation, and Partnerships effort through the Advanced Science and Partnerships for Integrated Resource Development (ASPIRED) program and associated partners, including the Government of Armenia, Armenia's Hydrogeological Monitoring Center, and the USAID Global Development Lab and its GeoCenter. The purpose of this report is to describe the hydrogeologic framework and groundwater conditions of the Ararat Basin in Armenia. The study area includes the Ararat Basin in Armenia and was expanded slightly from previous studies to include all wells included in the 2016 inventory.

The valleys of the Aras River and its tributaries form the intermountain depression known as the Ararat Basin (also known as Ararat Valley). The Ararat Basin is the most arid region of Armenia with annual precipitation of about 200-250 millimeters. Despite the arid climate, this region contains the country's largest agricultural and fish farming zone supported by high-quality water from wells completed into an artesian aquifer (unit) that underlies the Ararat Basin. Recharge to the artesian aquifer is through direct infiltration of precipitation and loss of flow in surface streams, especially in upland areas. Groundwater withdrawn from the artesian aquifer in the Ararat Basin of Armenia is used for municipal, irrigation, energy, industrial, and aquaculture uses. 
The hydrogeologic framework of the Ararat Basin contains basin fill and interbedded geologic material consisting of dense clays, gravels, sands, volcanic basalts, and andesite deposits. The basin is divided into a northern region and southern region by the Aras River. The northern region of the Ararat Basin, located in Armenia, is the primary focus area to delineate the hydrogeologic framework, in part, due to the sparse well information in the southern region located in Turkey. Using previously published cross sections and well lithologic logs, lithostratigraphic units were combined into nine hydrogeologic units. Of the nine layers identified in this study, four were identified as the potential water-bearing units. These four units consisted of interbedded sands and gravels and fractured basalts.

In 2016, using training provided by USGS, personnel from Hydrogeological Monitoring Center (under contract to the ASPIRED program) completed an inventory of wells to further define and characterize a hydrogeologic framework in and around the Ararat Basin. This inventory focused on approximately 2,800 wells completed in and around the Ararat Basin in Armenia. Historical water-level data were acquired from ASPIRED researchers for determining groundwaterlevel changes over time. The ASPIRED program provided water-level data from 2007 for about 1,600 wells in the Ararat Basin in Armenia. Potentiometric surface maps were developed for four hydrogeologic units in the Ararat Basin based on water-level data from the 2016 well inventory. As part of the well inventory in 2016, personnel from Hydrogeological Monitoring Center (under contract to the ASPIRED program) measured specific conductance and temperature in well water using USGS protocols.

Nine hydrogeologic units were identified as the primary units in the Ararat Basin, derived from the well inventory information provided by the ASPIRED researchers. The basin was divided into three subregions for purposes of describing the lithology, thicknesses, and density of wells that defined the units. The subregions were defined using rivers that flowed north to south. Water-bearing units were identified using lithologic descriptions for wells drilled in the Ararat Basin.

Data obtained during the well inventory were used to generate a map showing nonflowing and flowing wells in the Ararat Basin. The nonflowing aquifer conditions were on the edges of the Ararat Basin where the basin depth shallows. The artesian conditions and the cold water allowed Armenian aquaculture industries to utilize the naturally flowing artesian conditions to sustain fish farm operations.

Potentiometric surface maps were generated for each of the four hydrogeologic units classified as water bearing. In hydrogeologic unit 2, the estimated direction of groundwater flow is from the west to north in the western part of the basin (away from the Aras River) and from north to south (toward the Aras River) in the eastern part of the basin. In hydrogeologic unit 4, the direction of groundwater flow is generally from west to east and north to south (toward the Aras River) except in the western part of the basin where groundwater flow is toward the north or northwest. Unit 6 has this same general pattern of groundwater flow as unit 4. Hydrogeologic unit 8 is the deepest of the water-bearing units and is confined in the basin. Groundwater flow generally is from the south to north (away from the Aras River) in the western part of the basin and from west to east and north to south (toward the Aras River) elsewhere in the basin. The flow paths indicate that the Aras River is a losing stream (discharging to groundwater) in the western part of the basin; however, it is gaining (groundwater is discharging to the river) in the eastern part.

Data collected from 2,807 wells in 2016 were used to summarize water use in the Ararat Basin in Armenia. The water discharge from the 127 abandoned wells flowing to waste was 1,090 liters per second, which is an annual volume of about 34 billion liters. Most of the abandoned wells flowing to waste ( 75 percent) had previously been used for fish farming. By water-use category, the largest percentage of the wells (42 percent) was used for irrigation purposes. Fish farming constituted 17 percent of the wells, followed by drinking-household (15 percent), drinking-household plus irrigation (15 percent), and unused (flowing to waste) (7 percent). Over time, the flowing wells under artesian pressure reduced the pressure in the aquifer. As a result, many wells that were flowing have ceased to flow. The area within the Ararat Basin in Armenia with flowing wells (within the pressure boundary) was approximately 619 square kilometers in 1984, but decreased to 291 square kilometers in 2016. This is more than a 50-percent reduction in area between 1984 and 2016. The largest decreases (more than 2 meters) in hydraulic head between 2007 and 2016 were outside the 2016 pressure boundary. Within the pressure boundary, changes in hydraulic head generally were minimal or indicated slight increases.

Specific conductance and water temperature were measured by Armenian partners as part of the 2016 inventory using USGS protocols. Water from 540 wells were measured for specific conductance. The minimum specific conductance value was 377 microsiemens per centimeter $(\mu \mathrm{S} / \mathrm{cm})$, the maximum value was $4,000 \mu \mathrm{S} / \mathrm{cm}$, and the mean was $998 \mu \mathrm{S} / \mathrm{cm}$. The maximum water temperature was 24.2 degrees Celsius. An analysis between water temperature and well depth indicated no relation; however, spatially, most wells with cooler water temperatures are within the 2016 pressure boundary or in the western part of the basin. Wells with generally warmer water temperatures are located in the eastern part of the basin. Samples were collected from four groundwater and one surface-water site by USGS in 2016. The stable-isotope values were similar for all five sites indicating similar recharge sources for the sampled wells. The Hrazdan River sample was consistent with the groundwater samples, indicating the river could serve as a source of recharge to the Ararat artesian aquifer. 


\section{References Cited}

Armenian Branch of Mendez England and Associates, 2014, Assessment study of groundwater resources of the Ararat Valley_Final report: Prepared under subcontract agreement HAYJRNAKHAGITS-23/01/13-1 for U.S. Agency for International Development, $62 \mathrm{p}$.

Carter, J.M., Valder, J.F., Anderson, M.T., Meyer, Patrick, and Eimers, J.L., 2016, Building science-based groundwater tools and capacity in Armenia for the Ararat Basin: U.S. Geological Survey Fact Sheet 2016-3033, 4 p. [Also available at http://dx.doi.org/10.3133/fs20163033.]

Craig, H., 1961, Isotopic variations in meteoric waters: Science, v. 133, no. 3465, p. 1702-1703. [Also available at http://dx.doi.org/10.1126/science.133.3465.1702.]

Cunningham, W.L., and Schalk, C.W., comps., 2011, Groundwater technical procedures of the U.S. Geological Survey: U.S. Geological Survey Techniques and Methods, book 1, chap. A1, 151 p. [Also available at https://pubs.er.usgs.gov/ publication/tm1A1.]

Esri, 2017, Topo to Raster: Redlands, Calif., Esri, ArcGIS Desktop Help [online software documentation], accessed June 28, 2017, at http://desktop.arcgis.com/en/arcmap/ latest/tools/3d-analyst-toolbox/topo-to-raster.htm.

Hem, J.D., 1985, Study and interpretation of chemical characteristics of natural water (3d ed.): U.S. Geological Survey Water-Supply Paper 2254, 263 p.

Institute of Water Problems and Hydraulic Engineering after Academic Yeghiazarov of the Republic of Armenia, 2007a, Inventory and survey of technical state of groundwater wells and natural springs in the Ararat Marz: Consultant report (in Armenian).

Institute of Water Problems and Hydraulic Engineering after Academic Yeghiazarov of the Republic of Armenia, 2007b, Inventory and survey of technical state of groundwater wells and natural springs in the Armavir Marz: Consultant report (in Armenian).

Meyer, Patrick, 2015, Problem Statement 15-19-“"Build a model to analyze energy, environmental (water), and economic (E3) data for a minimum of 3 microhydro technologies used at aquaculture farms": Fishackathon, Devpost, accessed August 31, 2016, at https://fishackathon2015.devpost.com/forum_topics/4670.
Nalbandyan, Marine, 2012, Management and perspectives of using of underground freshwaters from transboundary aquifers in Armenia: 12th International Multidisciplinary Scientific GeoConference SGEM, June 17-23, v. 3, p. 769-775.

Reston Stable Isotope Laboratory, 2016, Instructions for collecting samples: U.S. Geological Survey, accessed January 2016, at https://isotopes.usgs.gov/lab/instructions.html.

Révész, Kinga, and Coplen, T.B., 2008a, Determination of the snake $\left({ }^{2} \mathrm{H} /{ }^{1} \mathrm{H}\right)$ of water-RSIL lab code 1574 : U.S. Geological Survey Techniques and Methods, book 10, chap. C1, 27 p. [Also available at https://pubs.usgs.gov/tm/2007/ tm10c1/.]

Révész, Kinga, and Coplen, T.B., 2008b, Determination of the $\delta\left({ }^{18} 0 /{ }^{16} 0\right)$ of water-RSIL lab code 489 : U.S. Geological Survey Techniques and Methods, book 10, chap. C2, 28 p. [Also available at https://pubs.usgs.gov/tm/2007/tm10c2/.]

U.S. Agency for International Development, 2008, Water resources atlas of Armenia: Yerevan, Armenia, U.S. Agency for International Development, $80 \mathrm{p}$.

U.S. Census Bureau, 2016, International programs-International data base-Demographic overview for 2015: accessed August 31, 2016, at http://www.census.gov/ population/international/data/idb/region.php.

U.S. Geological Survey, variously dated, National field manual for the collection of water-quality data (version 7): U.S. Geological Survey Techniques and Methods, book 9, chaps. A1-A9 [variously paged], accessed January 2016, at http://water.usgs.gov/owq/FieldManual/.

World Population Review, 2016, Armenia population 2016: accessed August 31, 2016, at http://worldpopulationreview. $\mathrm{com} /$ countries/armenia-population/.

Yu, Winston, Cestti, R.E., and Lee, J.Y., 2014, Toward integrated water resources management in Armenia: Washington, D.C., World Bank Group, accessed May 9, 2016, at http://dx.doi.org/10.1596/978-1-4648-0335-2. 
For more information about this publication, contact

Director, USGS Dakota Water Science Center, South Dakota Office 1608 Mountain View Road

Rapid City, SD 57702

(605) 394-3200

For additional information visit https://sd.water.usgs.gov

Publishing support provided by the

Rolla Publishing Service Center 

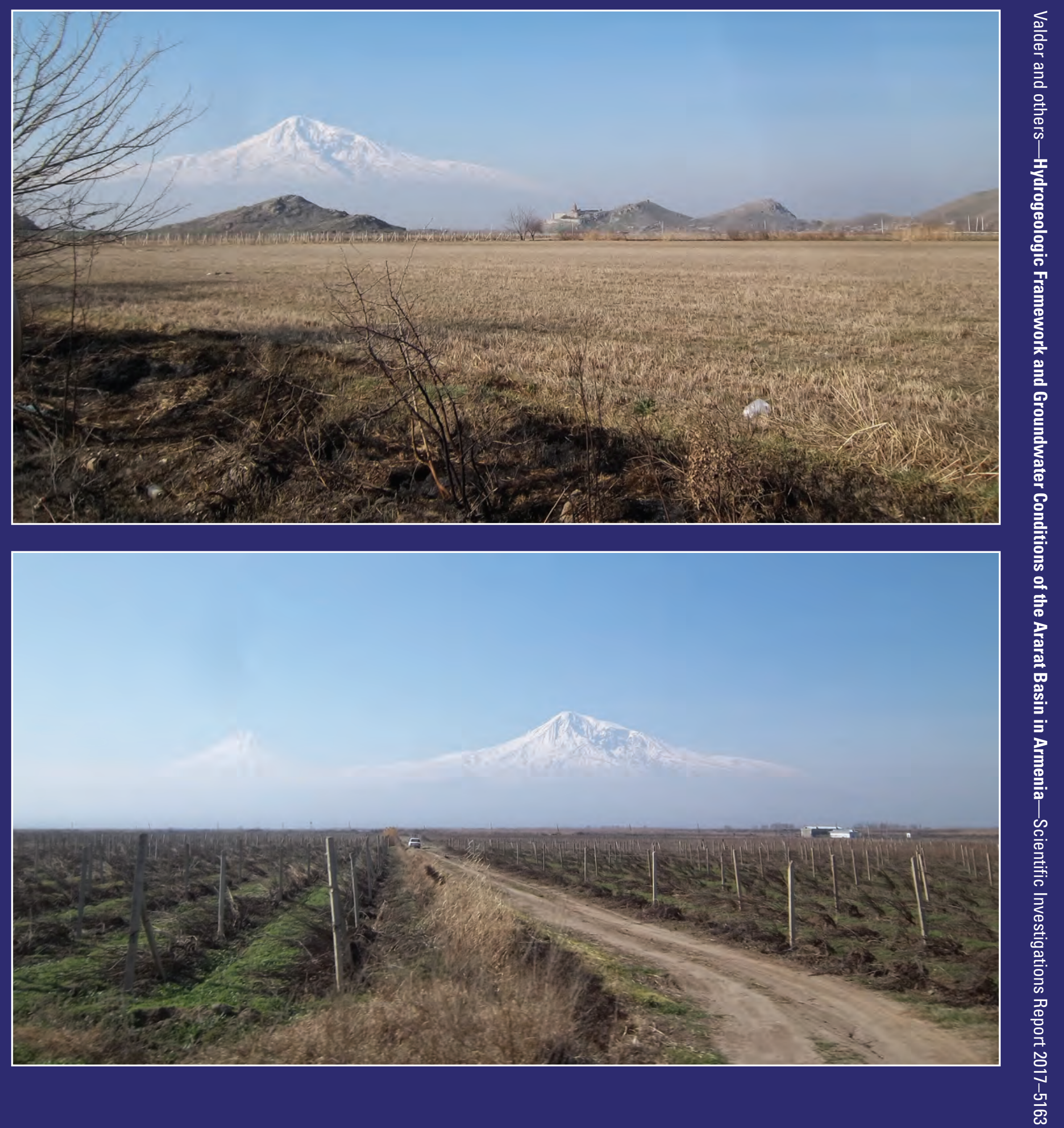

ISSN 2328-0328 (online 